\title{
TENSÕES PRESENTES NAS REFLEXÕES DOS PROFESSORES SOBRE O CURRÍCULO DA EDUCAÇÃO \\ DE JOVENS E ADULTOS*1
}

\author{
Ruth PaVAN, \\ da Universidade Católica Dom Bosco
}

\begin{abstract}
RESUMO: $\mathrm{O}$ artigo, fruto do projeto de pesquisa financiado pelo CNPq, tem como objetivo compreender a concepção de currículo escolar dos educadores de Ensino Fundamental e Ensino Médio da Educação de Jovens e Adultos (EJA), articulando-a com o multiculturalismo. Para alcançar esse objetivo, é apresentado um breve histórico da EJA e suas diferentes abordagens. Em seguida, há uma reflexão sobre o currículo escolar e seus significados feita por meio de um diálogo com os professores da EJA. Os dados foram coletados junto a eles com entrevistas semiestruturadas. Como resultado da pesquisa, é possível perceber que os professores da EJA trazem elementos importantes de uma proposta de currículo crítico, principalmente pela preocupação demonstrada com a contextualização dos conteúdos trabalhados em sala de aula.
\end{abstract}

Palavras-chave: Educação de Jovens e Adultos. Currículo. Reflexão. Multiculturalismo.

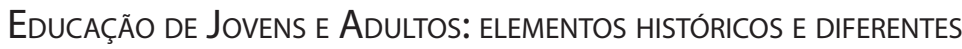
ABORDAGENS

Este artigo é fruto do projeto de pesquisa financiado pelo CNPq - "As concepções curriculares presentes na reflexão dos educadores da educação básica e suas implicações para o processo ensino e aprendizagem" - e analisa especificamente a concepção de currículo escolar dos educadores de Ensino Fundamental e Ensino Médio da Educação de Jovens e Adultos (EJA), articulando-a com o multiculturalismo.

\footnotetext{
* Artigo recebido em 15/7/2011 e aprovado em 1/8/2011.
} 
Inicialmente, trazemos os elementos históricos e as diferentes abordagens da Educação de Jovens e Adultos por entendermos que os professores são seres históricos. Portanto, suas falas e práticas carregam marcas construídas ao longo da história da educação, de modo mais específico neste texto, por diferentes concepções curriculares.

Lembramos que a Educação de Jovens e Adultos, de certa forma, sempre existiu no Brasil, se entendermos a educação em seu sentido mais amplo, como todo o tempo/espaço em que ocorrem processos de aprendizagem. Porém, pensando em Educação de Jovens e Adultos no seu sentido escolarizado, com base em Haddad e Di Pierro (2000), pode-se dizer que ela se inicia com os jesuítas, junto com o processo de colonização do Brasil. Fávero (2004) também observa que "o analfabetismo no Brasil é tema de discussão desde a Colônia e o Império. Mas é no início do século XX, principalmente após 1940, que passa a ser visto como um problema nacional" (p. 14).

Essa preocupação começou a aparecer na década de 1940, em grande parte por causa do movimento de educadores iniciado na década de 1920 que, já nesse período, procurava exigir do governo a adoção de políticas públicas específicas para a Educação de Jovens e Adultos. Também não se pode deixar de reconhecer que a exigência de uma maior escolarização está ligada ao processo de industrialização do Brasil, que, como sabemos, demandava uma formação maior do que na sociedade agrária. Nesse sentido, pode-se dizer que, por razões diferentes, tanto os movimentos de organização popular quanto a própria elite começaram a perceber a necessidade de uma educação mais universal. Os primeiros, por questões de cidadania; os segundos, por uma questão mercadológica. Além disso, os governos brasileiros começaram a sentir-se constrangidos diante dos maiores índices de alfabetização dos outros países, inclusive latino-americanos, o que, no contexto da nacionalização, era visto como um mal a ser superado para formar um só povo "ordeiro e trabalhador". A Constituição de 1934 (era Vargas) representou uma mudança significativa de mentalidade do governo.

Nos aspectos educacionais, a nova Constituição propôs um Plano Nacional de Educação, fixado, coordenado pelo governo federal, determinando de maneira clara as esferas de competência da União, dos estados e dos municípios em matéria educacional: vinculou constitucionalmente uma receita para a manutenção e o desenvolvimento do ensino; reafirmou o direito de todos e o dever do estado para com a educação; estabeleceu uma série de medidas que vieram confirmar este movimento de entregar e cobrar do setor público a responsabilidade pela manutenção e pelo desenvolvimento da educação. (HADDAD E DI PIERRO, 2000, p. 110) 
Cabe destacar que essa preocupação por parte do governo não significou uma valorização da cultura popular. Pelo contrário, os analfabetos eram tratados de forma pejorativa. Como destaca Fávero (2004),

a leitura dos artigos e relatórios da época revela uma definição preconceituosa do analfabeto, principalmente das áreas rurais: incompetente, marginal, culturalmente inferior etc. A referência evidente era a cidade, a sociedade que se industrializava; a cultura popular se restringia à divulgação da cultura considerada erudita às populações pobres e marginalizadas. (p. 15)

É nesse contexto que surgiu formalmente a Educação de Jovens e Adultos, passando a receber um tratamento diferenciado. Colaboraram para tanto a criação do Instituto Nacional de Estudos Pedagógicos (INEP) e a subsequente criação, em 1942, do Fundo Nacional do Ensino Primário, que, de forma progressiva, destinava recursos para o Ensino Supletivo. Some-se a isso a criação da Unesco em 1945, que chamava a atenção do mundo para as desigualdades sociais e via na educação um dos meios mais eficazes para superá-las. Assim, em 1947, foi instalado o Serviço de Educação de Adultos (SEA), um serviço especial do Ministério da Educação e Saúde que, entre outras medidas, integrou os serviços que já existiam nessa área, distribuiu materiais didáticos e sensibilizou a opinião pública. Em 1952, foi desenvolvida também a Campanha Nacional de Educação Rural e, em 1958, a Campanha Nacional de Erradicação do Analfabetismo. Ainda que essas duas campanhas tenham sido curtas e pouco eficazes, contribuíram para que a questão da Educação de Jovens e Adultos cada vez mais fizesse parte da agenda pública de educação. "Após uma atuação fragmentada, localizada e ineficaz durante todo o período colonial, Império e Primeira República, ganhou corpo uma política nacional, com verbas vinculadas e atuação estratégica em todo o território nacional" (HADDAD e DI PIERRO, 2000, p. 111). Dessa forma, houve uma diminuição significativa do analfabetismo, de modo que, em 1960, o número de analfabetos girava em torno de $46,7 \%$.

Vale ressaltar que, longe de ser uma dádiva do governo brasileiro em relação aos excluídos da educação, esse processo de inclusão escolar por meio da Educação de Jovens e Adultos só ocorreu em virtude de uma intensa organização e pressão popular. O governo viu-se forçado a atender aos anseios do povo, com o intuito de acomodar as tensões populares cada vez mais visíveis. Por outro lado, como já destaquei antes, contraditoriamente atendia também às exigências das novas elites - exigências de qualificação mínima para o novo mercado de trabalho -, bem como ia ao encontro da criação de uma nação livre e soberana, uma nação desenvolvida. 
Com o incremento da Educação de Jovens e Adultos, novas preocupações começaram a surgir, sobretudo por parte dos educadores, que passaram a perceber que era preciso desenvolver uma pedagogia própria para educar jovens e adultos. Essa preocupação ficou explícita em 1958, no II Congresso Nacional de Educação de Adultos, realizado no Rio de Janeiro, pois ficou clara a ideia de que o adulto estava sendo tratado como um "ser imaturo e ignorante, que devia ser atualizado com os mesmos conteúdos formais da escola primária" (HADDAD e DI PIERRO, 2000, p. 112). Assim, percebeu-se que, ainda que a intenção dos educadores fosse qualificar a cidadania, a educação desenvolvida dessa forma contribuía para reforçar os preconceitos. Novamente, deve-se destacar que essa percepção não foi fruto do acaso. Estava ligada às condições históricas do período em questão, um período marcado por grandes turbulências políticas e efervescência de movimentos sociais, em que a educação era vista como espaço privilegiado de conscientização das pessoas para participarem ativamente das lutas sociais em busca de melhores condições de vida. Só que não poderia ser qualquer forma de educação; era preciso encontrar uma pedagogia que fosse ao encontro dos interesses da classe trabalhadora: "foi dentro desta conjuntura que os diversos trabalhadores educacionais com adultos passaram a ganhar presença e importância. Buscava-se, por meio deles, apoio político junto aos grupos populares" (HADDAD E DI PIERRO, 2000, p. 113). Dessa forma, a Educação de Jovens e Adultos passou a ser vista como uma educação eminentemente política, sem perder de vista os aspectos pedagógicos inerentes ao processo de ensino e aprendizagem. Essa compreensão política da educação fez com que houvesse uma proliferação de campanhas e programas de Educação de Jovens e Adultos, mobilizando a sociedade nesse período e tendo, até o golpe de 1964, amplo apoio do governo federal. Dessa maneira, pela superação do modelo tradicional de educar os jovens e adultos, aliando a necessidade do conhecimento com o processo de conscientização e ação política, ela passou a ser vista como poderoso instrumento de intervenção política, bem como motor da valorização da cultura popular.

Ainda segundo Fávero (2004), também na década de 1960, a Igreja Católica mobiliza-se na reivindicação de um desenvolvimento mais equilibrado das regiões do Brasil, sobretudo do Nordeste, e na defesa das pessoas mais pobres. Nesse sentido, "a Igreja determina como prioridade a educação rural de massa e cria, por meio da Conferência Nacional dos Bispos do Brasil (CNBB) e apoiada pela Presidência da República, o Movimento de Educação de Base (MEB)" (p. 21). O movimento utiliza-se de "escolas radiofônicas" para ampliar o processo de alfabetização, com "recepção 
organizada", com monitores e voluntários preparados para o desempenho da tarefa de alfabetizar. Descentraliza os programas educativos, até então centralizados no Rio de Janeiro, para as microrregiões. No final de 1962, o MEB estabelece contato com outros movimentos de educação e cultura popular da época, apoiando o sindicalismo rural, que estava iniciando.

Ainda no início da década de 1960, em Recife, por iniciativa da Prefeitura, na gestão de Miguel Arraes, ocorre a criação do Movimento de Cultura Popular (MCP), para atender tanto crianças quanto adultos das populações mais pobres e objetiva enfatizar a "cultura como elemento fundamental de compreensão e transformação da realidade" (FÁVERO, 2004, p. 21). A proposta Paulo Freire de Alfabetização de Adultos também surge nesse período, com uma crítica radical às formas tradicionais de trabalhar a alfabetização, tendo como objetivo a transformação do espaço da sala de aula em um espaço democrático, de debate, de compreensão da realidade. Desses movimentos, surgem conhecidas produções, como “De pé no chão também se aprende a ler" e "Viver é lutar".

Diante disso, por tudo o que já foi escrito a respeito do período militar no Brasil, não se estranha nem um pouco o fato de esse movimento de educação popular de jovens e adultos ter sido violentamente reprimido pela ditadura, e de seus líderes terem sido reprimidos, perseguidos e censurados: "o Programa Nacional de Alfabetização foi interrompido e desmantelado, seus dirigentes, presos e os materiais apreendidos" (HADDAD e DI PIERRO, 2000, p. 113).

Porém, se, por um lado, a Educação de Jovens e Adultos com a finalidade de conscientização política foi severamente reprimida, houve, por outro lado, um incentivo por parte dos governos militares para movimentos conservadores, como foi o caso da Cruzada de Ação Básica Cristã, desenvolvida por pastores estadunidenses, que, segundo Haddad e Di Pierro (2000), tornou-se quase uma política oficial do governo militar, procurando ocupar os espaços de onde a educação popular de jovens e adultos havia sido expulsa. Fávero (2004) também observa que a Ação Básica Cristã era explicitamente contra a educação popular de Freire e estava "a serviço do 'Brasil Grande'e do anticomunismo" (p. 24). O governo militar, além da Cruzada da Ação Básica Cristã, criou o Movimento Brasileiro de Alfabetização (Mobral), que "foi concebido como um sistema que visava basicamente ao controle da população (sobretudo a rural)" (GADOTTI, 2005, p. 36).

Com a redemocratização em 1985, há um período em que as relações sociais se democratizam, e muitos direitos sociais são conquistados através dos antigos e novos movimentos sociais. Dessa forma, através da promulgação 
da Constituição de 1988, a educação fundamental de jovens e adultos passa a constar na legislação (federal, estadual e municipal) como gratuita e como dever do Estado. O fato de constar na legislação não significou que ela tenha sido efetivamente oferecida de modo a garantir o acesso a todos os jovens e adultos. A contradição entre a garantia jurídica e sua negação pela ausência de políticas públicas específicas manteve-se.

É importante destacar que a redemocratização significou a extinção do Mobral, pois, como se sabe, ele esteve fortemente vinculado à ideologia do governo militar e era visto como educação domesticadora, sem a necessária qualidade, sendo substituído, já em 1985, pela Fundação Nacional para Educação de Jovens e Adultos (Educar). Mesmo que a Fundação Educar tenha herdado do Movimento Brasileiro de Alfabetização muitos funcionários, questões burocráticas e algumas concepções pedagógicas, houve mudanças significativas. Particularmente, o que interessa destacar é que as práticas populares, vistas como subversivas pelo regime militar, passam a fazer parte novamente da Educação de Jovens e Adultos. Elas "retomam visibilidade nos ambientes universitários e passaram a influenciar também programas públicos e comunitários de alfabetização de jovens e adultos" (HADDAD e DI PIERRO, 2000, p. 120).

Nesse sentido, pode-se destacar que, em virtude da aprovação da Constituição de 1988, que na suas disposições transitórias estabelecia um prazo de 10 anos para erradicar o analfabetismo no Brasil e vinculava $50 \%$ dos recursos da educação a estes objetivos, isso fez com que nos anos seguintes houvesse uma significativa expansão e uma melhoria na qualidade da Educação de Jovens e Adultos. Além disso, pode-se salientar também que, incentivada pela própria legislação que diminuiu a idade mínima para o estudante frequentar a EJA (15 anos para o Ensino Fundamental e 18 para o Médio), houve uma mudança do público a ser atendido por essa modalidade de educação. Antes, o público era formado, na sua maioria, por adultos provenientes da zona rural. Agora, passam a ser predominantemente jovens da zona urbana que, por um motivo ou outro, foram excluídos da educação básica regular.

Ressalto ainda, citando Soares (2002), a Lei de Diretrizes e Bases da Educação Nacional (LDB) como um fator que representou a consolidação da mudança significativa na Educação de Jovens e Adultos. Nas palavras do autor:

Ainda que a LBD 9.394/96 tenha sido uma colcha de retalhos ao tentar conciliar interesses governistas, privatistas e publicistas, nos arts. 37 e 38, que dizem respeito diretamente à Educação de Jovens e Adultos, a lei incorporou a mudança conceitual de EJA que se dava desde o final dos anos de 1980. A 
mudança de "ensino supletivo" para "educação de jovens e adultos" não é uma mera atualização vocabular. Houve um alargamento do conceito ao mudar a expressão de ensino para educação. Enquanto o termo "ensino" se restringe à mera instrução, o termo "educação" é muito mais amplo, compreendendo os diversos processos de formação. (SOARES, 2002, p. 12)

Eé sob a égide dessa LDB que estamos vivenciando a EJA atualmente. Assim, após este breve histórico da Educação de Jovens e Adultos, passamos a desenvolver a discussão sobre a compreensão de currículo e também das possibilidades de praticar um currículo multicultural, dos professores de Ensino Fundamental e Ensino Médio da EJA, entendendo que essa compreensão está atravessada pelo contexto histórico.

\section{O CURRÍCULO ESCOLAR E O DIÁLOGO COM OS PROFESSORES}

Os professores citados neste artigo foram escolhidos com base nos critérios estabelecidos no projeto de pesquisa que assinala que os professores entrevistados devem atuar na Educação Básica, ser de diferentes áreas de conhecimento e pertencer à mesma escola para que a compreensão sobre currículo esteja vinculada a uma mesma proposta pedagógica. Para a coleta de dados, foram utilizadas entrevistas semiestruturadas. Neste artigo, os professores entrevistados são todos pertencentes à Educação Básica de Jovens e Adultos.

Para iniciarmos nosso diálogo com os professores, ressaltamos o debate dos teóricos críticos da educação para caracterizar de que forma estamos abordando o currículo escolar:

O currículo representa muito mais do que um programa de estudo, um texto de sala de aula ou o vocabulário de um curso. Mais do que isto, ele representa a introdução de uma forma particular de vida; ele serve, em parte, para preparar os estudantes para posições dominantes ou subordinadas na sociedade existente. (MCLAREN, 1997, p. 216)

Destacamos que nossa compreensão de currículo se afasta do que o autor afirma ser "um programa de estudo, um texto de sala de aula" ou, ainda, um "vocabulário de um curso", pois tal compreensão se aproxima do que Silva (2004) ou mesmo Moreira e Silva (1995) vão denominar de um currículo tradicional, ou seja, uma perspectiva que não questiona as diferentes relações sociais que atravessam o currículo escolar. Aliamo-nos à perspectiva que McLaren (1997) e Silva (2004), entre outros, vão denominar de uma abordagem crítica de currículo, segundo a qual este não se limita a "um texto de sala de aula", mas, como citamos anteriormente, "representa a introdução 
de uma forma particular de vida". O currículo, segundo a perspectiva crítica, está estreitamente articulado com as diferentes formas de produção da vida em sociedade.

Juntamente com os teóricos críticos da educação, entendemos o currículo "como forma de política cultural, ou seja, como uma parte da dimensão sociocultural do processo de escolarização" (MCLAREN, 1997, p. 218). Portanto, de forma diferente da visão tradicional, segundo a qual ele se limita a um "elenco de disciplinas ou listagem de conteúdos" (BERTICELLI, 1999, p. 171), ignorando o fato de ele ser fruto de uma seleção ou disputa para inclusão ou exclusão de determinados conteúdos, expressões culturais, visões de mundo e outros.

Tendo como base essa concepção crítica de currículo, passamos a analisar a compreensão que professores da Educação Básica de Educação de Jovens e Adultos têm acerca do currículo escolar. Para a professora Sirlei, "currículo é tudo que a escola tem que trabalhar, tudo faz parte, até os alunos fazem parte desse currículo" (Sirlei, professora de Língua Portuguesa da primeira e da segunda fase do Ensino Médio da EJA).

Esta professora apresenta-nos uma compreensão que não se restringe a uma visão tradicional de currículo, o que pode ser apontado como um elemento significativo de sua reflexão. Segundo McLaren (1997), as tradições educacionais e culturais dominantes - e nelas evidentemente estão incluídas as concepções de currículo - "têm sido vítimas de uma racionalidade instrumental (uma maneira de ver o mundo na qual os 'fins' são subordinados a questões de 'meios' e na qual os 'fatos' são separados das questões de 'valor')" (MCLAREN, 1997, p. 219), o que, de acordo com o autor, "limita ou ignora ideais e princípios democráticos" (p. 219). É importante destacar que os princípios democráticos estão na base da Educação de Jovens e Adultos. ${ }^{2}$ Não ter uma compreensão de currículo tradicional, meramente instrumentalizadora, ${ }^{3}$ é um aspecto a ser destacado como positivo, pois isso faz com que essa educadora tenha melhores condições de compreender a realidade dos seus alunos da EJA e, portanto, maiores possibilidades de desenvolver uma educação democrática.

Os professores José e Ana também trazem elementos do currículo crítico:

Eu acho o currículo escolar um pouco limitado, ele prende muito a uma grade curricular. Eu acho que o currículo deveria ser voltado para o dia a dia do aluno, para as histórias diárias do aluno, não só para o conhecimento livresco. (José, professor de História da terceira e da quarta fase do Ensino fundamental da EJA) 
Acredito que é um suporte para nós, não a ser seguido ali como receita, mas ele abre para nós, professores, algum caminho, vamos dizer assim, alguns parâmetros a seguir, né, então, ali eles dão é... subsídios para que nós trabalhemos o conteúdo de sala, eu penso isso, não tenha que ser seguido como receita, mas dar um embasamento pra gente. Um referencial. (Vera, professora de Língua Portuguesa da terceira e da quarta fase do Ensino Fundamental da EJA)

Percebemos, na compreensão dos professores citados, elementos de uma abordagem crítica de currículo, pois é possível perceber uma ampliação do currículo para além da "grade curricular" (Professor José) e não segui-lo como uma "receita" (Professora Vera).

Num certo sentido, pode-se dizer que esses professores se aproximam da ideia de que o processo educativo - portanto, o currículo - está "profundamente implicado na política cultural"(APPLE, 2000, p. 53), ou seja,

o currículo nunca é simplesmente uma montagem neutra de conhecimentos, que de alguma forma aparece nos livros e nas salas de aula de um país. Sempre parte de uma tradição seletiva, da seleção feita por alguém, da visão que algum grupo tem do que seja conhecimento legítimo. Ele é produzido pelos conflitos, tensões e compromissos culturais, políticos e econômicos que organizam e desorganizam um povo. (APPLE, 2000, p. 53)

Entendemos que as afirmações desses professores se aproximam de Apple (2000) porque, nas suas falas, há uma problematização do currículo. Esses professores não o veem apenas como uma lista de conteúdos a serem trabalhados.

Por outro lado, alguns professores ainda apresentam uma compreensão mais tradicional de currículo, ou seja, mais vinculada à ideia de que se trata de uma lista de conteúdos escolares:

Olha, na verdade não sou eu que defino. Quando eu comecei a dar aula, esse currículo já era uma divisão rígida. Eu não posso falar rígida, né, mas uma divisão consagrada, então, o $1^{\circ}$ ano vê um determinado conteúdo, o $2^{\circ}$, outro, e o $3^{\circ}$, outro, entendeu? (João, professor de Física da primeira e da segunda fase do Ensino Médio da EJA)

Apesar de o professor não se mostrar conformado com a maneira como o currículo vem sendo desenvolvido, percebe-se que ele trabalha na perspectiva do que está estabelecido burocraticamente, o que o remete à concepção tradicional. A professora Mirna fala algo semelhante:

O currículo escolar... Eu acho assim que é necessário. Não sei se teria que passar por uma adaptação, porque hoje está tudo mudado, né, mesmo no 
concurso público que exige ainda muito do português, muita gramática, mas o vestibular já não. (Mirna, professora de Língua Portuguesa da primeira e da segunda fase do Ensino Médio)

A professora aponta a necessidade de fazer uma "adaptação" do currículo. No entanto, essas adaptações estão vinculadas ao conteúdo curricular, subentendo-se que não seriam feitas pelos educadores, mas por agentes externos (órgãos oficiais). Segundo a professora Paula,

o currículo escolar é uma sequência de conteúdos a serem trabalhados de acordo com aquele plano maior que a gente tem que seguir, que é nível estadual, né, e que a gente precisa, a partir desse norteamento, então, a gente passa a elaborar o currículo, que vai atender ao ano ou à fase, no caso, que a gente vai trabalhar. (Professora Paula, pedagoga, atua na primeira e na segunda fase do Ensino Fundamental)

Como se observa, a professora Paula enfatiza os conteúdos oficiais, não apresentando nenhuma problematização, e salienta que deve segui-los: "a gente tem que seguir".

Porém, mesmo esses professores, quando questionados sobre se os conteúdos curriculares estão articulados com outros contextos fora do ambiente escolar, demonstram perceber essa articulação, tão importante para uma perspectiva crítica de currículo:

[...] porque não tem como você trabalhar física sem sair da sala de aula [...]. Leis de Newton na engenharia, no trânsito, 'por que o cinto de segurança?', 'por que o cara na construção usa uma viga?', 'você vai construir uma casa, a sustentação ...' Aí, sempre você tem que ver... Puxar para o concreto. (Professor João).

Para a professora Mirna, o currículo está relacionado a "questões sociais, meio ambiente, saúde, comportamento, tudo". Também para a professora Paula, é importante trabalhar o currículo escolar na perspectiva de atender às necessidades dos alunos. Conforme sua fala,

além dos temas transversais que a gente trabalha, muitas vezes, a gente se depara com situações que a gente tem que abrir dentro daquilo que a gente pretendia trabalhar, abrir assim um leque de instruções pra atender àquela necessidade que o aluno traz. Eu tive um caso de um aluno pedreiro, que ele precisava resolver um problema de área de uma figura triangular porque estava sendo exigido no trabalho dele. Ele pediu que eu trabalhasse isso em sala porque ele tinha interesse e ele sabia fazer isso na prática, mas ele precisava desenvolver isso com uma fórmula, de maneira que ele pudesse resolver de maneira rápida e pudesse apresentar para o engenheiro de onde 
ele trabalhava. [...] eu tive que antepor esse conteúdo [...] para atender a essa necessidade dele, e a gente acabou trabalhando na sala de aula.

Assim, podemos observar que os professores, que num primeiro momento restringem o currículo escolar aos conteúdos (oficiais), quando questionados sobre outros possíveis atravessamentos que esses conteúdos podem sofrer, explicitam uma postura de entendimento crítico de currículo, ou seja, de que o aluno e o próprio conteúdo são contextualizados; portanto, o currículo deve estar relacionado com a sociedade, com o trabalho, com a vida. Pode-se dizer que os educadores sofrem as influências de diferentes currículos construídos/teorizados ao longo da história da educação e da própria EJA.

Para ampliar a discussão acerca do currículo escolar, apresentaremos os questionamentos feitos aos professores sobre a possibilidade da construção de um currículo multicultural na sala de aula.

\section{O CURRículo MULTICULTURAL E A EJA: A COMPREENSÃo dOS PROFESSORES}

Conforme já estamos discutindo ao longo deste texto, reiteramos a posição de que currículo e sociedade estão profundamente articulados. Queremos destacar que a cultura, como componente de toda e qualquer sociedade, também está relacionada com o currículo, pois entendemos que a escola, como tantos outros locais, é um espaço onde as diferentes culturas ficam em evidência. Mais que isso, muitas vezes essas diferentes culturas presentes nas escolas sofrem processos de discriminação, ou seja, reproduzem-se hierarquizações entre os diferentes grupos culturais que podem ser observadas ao longo da história. Por isso, uma abordagem curricular que leve em conta o multiculturalismo é necessária, pois "não há educação que não esteja imersa na cultura da humanidade e, particularmente, no momento histórico e do contexto em que se situa" (CANDAU, 2006, p. 39).

Portanto, pensar o currículo de uma forma multicultural implica reconhecer a relação entre educação e cultura, propondo uma discussão curricular para não restringir o currículo aos conteúdos formais:

Neste sentido, não é possível conceber uma experiência pedagógica 'desculturizada', isto é, em que nenhum traço cultural específico se configure. Existe uma relação intrínseca entre educação e cultura. Esses universos estão profundamente entrelaçados e não podem ser analisados a não ser a partir de sua íntima articulação. (CANDAU, 2006, p. 39)

Esta discussão tem se apresentado tanto pelo questionamento do "caráter em geral padronizador, homogeneizador e monocultural da educação" (CANDAU, 2006, p. 39), quanto pela necessidade de "construir práticas 
educativas em que a questão da diferença e do multiculturalismo se faça cada vez mais presente" (p. 40).

Na percepção de parte dos professores entrevistados, o multiculturalismo "é o conjunto de culturas numa sala, né, o conjunto de conhecimentos diferentes" (Janice, professora de Biologia da terceira e da quarta fase do Ensino Fundamental e da primeira e da segunda fase do Ensino Médio da EJA); "multiculturalismo... seria uma mistura de culturas, não seria?", ou "as várias culturas que formam a nossa sociedade, né?" (Mirna, professora de Língua Portuguesa da primeira e da segunda fase do Ensino Médio); "várias culturas" (Marli, professora de Biologia da terceira e da quarta fase do Ensino Fundamental); "bem, se for fazer uma análise da palavra em si, multi quer dizer várias, com a palavra culturas, então, seria várias culturas misturadas, isso" (Vera, professora de Língua Portuguesa da terceira e da quarta fase do Ensino Fundamental). Segundo o professor João,

seria mais ou menos... Seriam várias culturas que nós temos dentro da nossa escola, se tem lá uma pessoa que mora na periferia ou que mora na favela, você tem, por exemplo, alunos filhos de professores meus [...] professor de faculdade, o cara tem uma cultura diferente. (João, professor de Física da primeira e da segunda fase do Ensino Médio da EJA)

Como se pode ver pelas respostas destes professores, eles apresentam uma reflexão sobre multiculturalismo bastante restrita a decodificar a palavra. No entanto, quando questionados sobre a possibilidade de trabalhar um currículo multicultural em sala de aula, todos se mostraram favoráveis, embora dissessem também que não seria tarefa fácil, o que nos faz lembrar Silva (2004), quando escreve: "o multiculturalismo não pode ser separado das relações de poder que, antes de mais nada, obrigaram essas diferentes culturas raciais, étnicas e nacionais a viverem no mesmo espaço" (p. 85).

O reconhecimento da importância do multiculturalismo e a posição favorável dos educadores vêm ao encontro do que pontua Candau "a questão multicultural nos últimos anos adquire cada vez maior abrangência, visibilidade e conflitividade, no âmbito internacional, continental e local. Essa problemática preocupa hoje muitas sociedades" (2005, p. 13).

Além das falas de educadores que ficam mais restritas ao significado da palavra multiculturalismo, há falas que revelam uma compreensão mais complexificada das implicações dessa forma de conceber a educação e o currículo. Nesse sentido, destacamos as falas das professoras Paula e Sirlei:

Multiculturalismo... Seriam as informações de diversas culturas que ocorrem na escola, como ocorre na sociedade em geral, informações hoje, nesse 
mundo globalizado, que não se limitam às paredes da sala de aula, que não se limitam ao bairro, a uma cidade, e que fazem parte de todo o mundo, e hoje em dia está tudo integralizado, não tem mais como isolar de tudo que acontece. (Professora Paula, pedagoga, atua na primeira e na segunda fase do Ensino Fundamental)

O termo multiculturalismo está ligado à diversidade, à convivência com as diferenças, respeito pelas diferenças. Porque isso existe no papel, né, como é complicado. Eu observo de monte como é complicado trabalhar isso com o aluno, por exemplo, essa questão do homossexualismo, das questões relacionadas à raça, das questões relacionadas à diferença econômica. $E$ eu tenho, assim, uma situação privilegiada, porque eu trabalho com escola pública e com escola particular, e essa questão é em todo lugar, né. As questões relacionadas a deficiências, às dificuldades de locomoção, todas essas questões. (Sirlei, professora de Língua Portuguesa da primeira e da segunda fase do Ensino Médio)

Essas falas vêm ao encontro do que escrevem Canen e Oliveira (2002) sobre o multiculturalismo, concebendo-o tanto como campo teórico quanto político, ou seja, o multiculturalismo refere-se à necessidade "de compreender-se a sociedade como constituída de identidades plurais, com base na diversidade de raças, gênero, classe social, padrões culturais e linguísticos, habilidades e outros marcadores identitários" (p. 61). Ainda segundo as autoras, o multiculturalismo rompeu epistemologicamente com o projeto da modernidade, que acreditava na "homogeneidade e na evolução 'natural' da humanidade rumo a um acúmulo de conhecimentos que levariam à construção universal do progresso" (p. 61).

\section{CONSIDERAÇÕES FINAIS}

Como se pôde observar pela pesquisa efetuada, os professores entrevistados carregam as marcas da história da educação e do currículo; de certa forma, pode-se dizer que estão numa fase de transição, alguns ainda estão muito influenciados pelo currículo tradicional, outros menos, mas todos, em alguns momentos da entrevista, dão indícios de que são também influenciados pelas concepções críticas, inclusive, fazendo alguns ensaios sobre o multiculturalismo.

Também, penso que a pesquisa aponta para algo fundamental no contexto atual: a necessidade de que a Educação de Jovens e Adultos seja problematizada desde o seu currículo para que não corramos o risco de tratá-la de forma burocratizada e domesticadora como foi tratada no passado. É preciso que ela tenha, no presente, uma perspectiva crítica não 
discriminatória para que represente, de fato, uma melhor qualidade de vida para os seus alunos.

\section{TENSIONS REFLECTED IN THE THINKING OF TEACHERS ABOUT THE YOUTH AND ADULT EDUCATION CURRICULUM}

AвSTRACT: The aim of this article, the result of a research project financed by CNPq, is to understand the concepts of school curriculum held by Primary and Secondary School teachers in the Education of Young People and Adults (EJA), linking them to multiculturalism. To achieve this goal, a brief historical outline of EJA and its different approaches is presented. Then there is a reflection on the school curriculum and its meanings, as well as a dialogue with EJA teachers. Data was collected from the teachers by means of semi-structured interviews. As a result of the research it can be seen that the EJA teachers present important elements for a proposed critical curriculum, mainly through their concern to contextualize the subject content used in the classroom.

Keywords: Education of Young People and Adults. Curriculum. Reflection. Multiculturalism.

\section{NOTAS}

1.Versão revisada e ampliada do trabalho apresentado no VI Congresso Internacional de Educação - Educação e Tecnologia: sujeitos (des)conectados, UNISINOS, agosto de 2009.

2. Conforme mostram as estatísticas, muitos jovens e adultos passaram pela escola sem ter aprendido a ler e escrever. "O fracasso escolar que penaliza as crianças das classes populares adquire novas formas de expressão, mas continua denunciando a necessidade de se aprofundar o processo de democratização da sociedade, sendo significativa a produção da escola pública como espaço de educação popular de qualidade para todos" (ESTEBAN, 2004, p. 168).

3. O que seria uma volta à EJA com características do Mobral, visto que ela já é criticada pelos teóricos, como vimos na primeira parte deste artigo.

\section{REFERÊNCIAS}

APPLE, Michael W. Política cultural e educação. São Paulo: Cortez, 2000.

BERTICELLI, Ireno Antonio. Currículo: tendências e filosofia. In: COSTA, Marisa Vorraber (Org.). O currículo nos limiares do contemporâneo. Rio de Janeiro: DP\&A, 1999. p. 159-176.

CANDAU, Vera Maria. Sociedade multicultural e educação: tensões e desafios. In: CANDAU, Vera Maria (Org.). Cultura(s) e educação: entre o crítico e o pós-crítico. Rio de Janeiro: DP\&A, 2005. p. 9-37. 
CANDAU, Vera Maria. O/a educador/a como agente cultural. In: LOPES, Alice R.C., MACEDO, Elizabeth F. de. ALVES, Maria P. C. (Orgs.). Cultura e política de currículo. Araraquara, SP: Junqueira e Marin, 2006. p. 35-52.

CANEN, Ana e OLIVEIRA, Ângela M. A. de. Multiculturalismo e currículo em ação: um estudo de caso. Revista Brasileira de Educação, Rio de Janeiro, n. 21, p. 61-74, set./out./ nov./dez. 2002.

ESTEBAN, Maria Teresa. Diferença e (des) igualdade no cotidiano escolar. In: GARCIA, Regina Leite e outros (Orgs.). Currículo: pensar, sentir e diferir. Rio de Janeiro: Dp\&A, 2004. p. 159-177.

FÁVERO, Osmar. Lições da história: os avanços de sessenta anos e a relação com as políticas de negação de direitos que alimentam as condições do analfabetismo no Brasil. In: OLIVEIRA, Inês Barbosa; PAIVA, Jane (Orgs.). Educação de jovens e adultos. Rio de Janeiro: DP\&A, 2004. p. 13-28.

GADOTTI, Moacir. Educação de jovens e adultos: correntes e tendências. In: GADOTTI, Moacir e ROMÃO, José E. (Orgs.). Educação de jovens e adultos: teoria, prática e proposta. São Paulo: Cortez, 2005. p. 29-39.

HADDAD, Sérgio; DI PIERRO, Maria Clara. Escolarização de jovens e adultos. Revista Brasileira de Educação, São Paulo, n. 14, p. 108-130, maio/jun./jul./ago. 2000.

MCLAREN, Peter. A vida nas escolas: uma introdução à pedagogia crítica nos fundamentos da educação. Porto Alegre: Artes Médicas, 1997.

MOREIRA, Antonio Flávio e SILVA, Tomaz Tadeu. Sociologia e Teoria crítica do currículo: uma introdução. In: MOREIRA, Antonio Flávio e SILVA, Tomaz Tadeu (Orgs.). Currículo, cultura e sociedade. São Paulo: Cortez, 1995. (p. 7-37).

SILVA, Tomaz Tadeu. Documentos de identidade: uma introdução às teorias do currículo. Belo Horizonte: Autêntica, 2004.

SOARES, Leôncio José Gomes. Educação de jovens e adultos. Rio de Janeiro: DP\&A, 2002.

RUTH PAVAN é doutora em Educação e professora do Mestrado e Doutorado em Educação da Universidade Católica Dom Bosco.

E-mail: ruth@ucdb.br 



\title{
RELATOS SOBRE "SALAS ALTERNATIVAS DE EDUCAÇÃO DE JOVENS E ADULTOS" PARA PESSOAS COM NECESSIDADES EDUCATIVAS ESPECIAIS: UM OLHAR NO PASSADO COM VISTAS PARA O FUTURO*
}

\author{
Dulce Barros de Almeida, \\ da Universidade Federal de Goiás
}

\begin{abstract}
Resumo: Este artigo discute as alternativas encontradas pela Rede Estadual de Educação de Goiás para o atendimento de jovens e adultos com necessidades educativas especiais no início desse século. Trata-se de uma discussão baseada em pesquisa qualitativa de abordagem descritivo-reflexiva que utilizou como instrumentos de coleta de dados as técnicas de observação, entrevistas e análises de documentos. Objetivou analisar como as Salas Alternativas de Jovens e Adultos (SAEJA) se estruturaram e se desenvolveram para dar suporte às pessoas que historicamente foram marginalizadas e excluídas do sistema educacional brasileiro por não atenderem às suas exigências. Dentre as conclusões encontradas, destaca-se o descaso do governo estadual a essa população-alvo, sobretudo no que se refere à concepção de educação de jovens e adultos com necessidades educativas especiais, quer sejam por limitações intelectuais, sensoriais ou físicas, que ainda se encontram à margem de uma educação adequada e de qualidade.
\end{abstract}

Palavras-chave: Salas Alternativas. Jovens e Adultos. Pessoas com Necessidades Educativas Especiais.

INTRODUÇÃO

Este artigo baseia-se em um recorte de pesquisa realizada para a elaboração da tese de doutorado "Do especial ao inclusivo? Um estudo da proposta de inclusão escolar da rede estadual de Goiás, no município de

\footnotetext{
* Artigo recebido em 09/06/2011 e aprovado em 03/09/2011.
} 
Goiânia", defendida e aprovada pela Universidade Estadual de Campinas UNICAMP - em 2003.

A justificativa para esse recorte tem como fundamento a contribuição que se pretende dar aos estudos que estão sendo aprofundados cada vez mais por especialistas da área sobre as situações em que se encontram as pessoas jovens e adultas acometidas por algum tipo de deficiência, que as levam à categoria de pessoas com necessidades educativas especiais no ensino brasileiro.

Para Lajonquière (2001, p. 50), falar em deficiente ou em necessidades especiais não há diferença alguma, pois "o déficit é uma falta a ser apagada por reeducação ou reabilitação enquanto a necessidade é uma falta a ser satisfeita com a educação". Assim, para este autor, mudam-se apenas os nomes, mas as ideias permanecem.

Os dados foram coletados em seis salas de aula de escolas estaduais consideradas como "inclusivas e de referência", por meio da observação participante nos períodos matutino, vespertino e noturno; da análise de documentos primários e secundários e de entrevistas semiestruturadas realizadas tanto com professores como com gestores responsáveis, direta ou indiretamente, pelo desenvolvimento dessas salas alternativas para o atendimento de jovens e adultos. Procurou-se compreender como foi possível a estruturação dessas salas de aula em um contexto educacional considerado "oficialmente" inclusivo pelo governo estadual.

Respostas convincentes para essa questão não são fáceis, entretanto, bastou consultar os documentos vigentes tanto em âmbito nacional quanto regional, para saber como elas foram sendo legitimadas.

No Informativo 001/2000 do Gabinete da então Superintendência de Ensino Especial da Secretaria Estadual de Educação (SUEE/SEE), encontra-se uma explicação para a existência dessas salas. Elas se incluem no Projeto Diversidades - uma alternativa inclusiva de jovens e adultos com necessidades especiais, elaborado pela SUEE. No corpo do projeto, fica esclarecido que se trata de uma parceria entre a Superintendência de Ensino Especial e a então Superintendência de Ensino a Distância e Continuada também vinculada à Secretaria Estadual de Educação (SEADEC/SEE). Suas proposições assim são definidas:

Propomos uma adaptação do Programa de Educação de Jovens e Adultos para pessoas com necessidades educacionais especiais, que apresentam defasagem idade/série. Isto se dará através da implantação de salas alternativas para viabilização deste atendimento aos alunos acima de 12 anos, com deficiências, dificuldades de aprendizagem ou que não tiveram acesso à es- 
colarização em idade própria. Deverão ser atendidos inicialmente, os alunos de $1^{\mathrm{a}}$ a $4^{\mathrm{a}}$ séries do Ensino Fundamental, em turmas inclusivas compostas por no mínimo 12 e no máximo 15 alunos, agrupados numa sala de $1^{\text {a }}$ e $2^{\text {a }}$ séries e outra de $3^{\mathrm{a}}$ e $4^{\mathrm{a}}$ séries. A formação das turmas deverá obedecer aos princípios da educação inclusiva, numa perspectiva de atendimento à diversidade. Os professores que assumirem estas turmas deverão ter habilitação para o ensino fundamental de $1^{\mathrm{a}} \mathrm{a} 4^{\mathrm{a}}$ séries, preferencialmente pedagogos. As salas deverão funcionar nos turnos matutino e vespertino. No noturno, somente quando houver demanda suficiente de alunos em idade permitida pela legislação vigente e aquiescência dos pais ou responsáveis. O currículo seguirá adaptações necessárias à realidade dos alunos. Os conteúdos serão trabalhados de forma dinâmica, utilizando métodos adequados, recursos da comunidade, tais como: arte-educação, esporte e lazer, informática educacional e outros, sempre que possível. O processo avaliativo dos alunos compreenderá o respeito aos diferentes ritmos de aprendizagem. Será feito de maneira sistemática, descritiva e contínua, servindo também como instrumento norteador do planejamento e posturas didático - pedagógicas dos educadores. A aprovação dos alunos respeitará os processos legais de seriação, conforme a produtividade dos mesmos, assegurando a legalidade desta sala. O projeto contará com um adendo anexado ao Programa original, com aprovação do Conselho Estadual de Educação. (GOIÁS/SEE/SUEE, 2000, p. 1-2, grifo nosso)

A SUEE/SEE utilizou a Lei Diretrizes e Bases da Educação Nacional, Lei n. 9.394/96, como respaldo legal para a criação das SAEJA, pois no Cap. II, Seção V, art. 37, parágrafo 1, recomenda:

Os sistemas de ensino assegurarão gratuitamente aos jovens e aos adultos, que não puderam efetuar os estudos na idade regular, oportunidades educacionais apropriadas, consideradas as características do alunado, seus interesses, condições de vida e de trabalho, mediante cursos e exames.

As Diretrizes Nacionais para a Educação Especial na Educação Básica, do CNE/CEB, 2001, também recomendam a criação de classes especiais, mesmo que extraordinariamente. Desse modo, fica respaldado todo tipo de iniciativa que cria no ensino regular modalidades de atendimentos segregados para as pessoas que apresentam necessidades educacionais especiais. No caso das SAEJA, o argumento da SUEE para sua criação é o de incluir alunos jovens e adultos com necessidades especiais na escolarização, mas praticamente em todo o Estado de Goiás, os programas regulares de jovens e adultos já são abertos à comunidade.

Vale ressaltar que a maioria dos alunos jovens e adultos que frequentavam as SAEJA estudaram, quando crianças, em escolas especiais ou classes 
especiais com o objetivo de serem escolarizados e, se possível, incluídos no sistema educacional regular. Mas, é possível aferir que, como a prioridade do ensino especial em Goiás e no Brasil, nas décadas anteriores, resumia-se ao atendimento clínico e não ao educacional, esse objetivo não foi alcançado.

É importante esclarecer que não se teve como proposta ou objetivo, na elaboração desse artigo, a atualização de como essas salas alternativas se encontram hoje no âmbito da Secretaria Estadual de Educação de Goiás.

O que se pretendeu, de fato, foi o desvelamento de situações de discriminação as pessoas jovens e adultas com necessidades educativas especiais têm vivenciado ainda no início desse século, para que esse passado recente seja evitado e abominado de qualquer política de governo estadual, que tenta mascarar, no seu discurso de democratização, a forma natural e contínua que tem dado à exclusão escolar.

\section{RELATOS DE UMA REALIDADE VIVIDA E OBSERVADA}

A seguir, será apresentada uma síntese das observações feitas em salas alternativas para jovens e adultos com necessidades educativas especiais, registradas em Diários de Campo, assim como algumas análises.

O espaço físico da sala I me causou impacto, pois era totalmente diferente dos demais da própria escola. Percebi que era um local improvisado, pequeno, apesar do número também pequeno de alunos (11). Tanto a direção e coordenação como a própria professora afirmaram que o objetivo desta sala era o de atender, no período matutino, jovens e adultos com deficiência ou não, de forma integrada, que não tiveram oportunidades educacionais anteriormente. Constatei, entretanto, que todos os alunos presentes eram pessoas com deficiência, situavam na faixa etária entre 12 e 31 anos, e oito deles eram egressos de escola ou classe especial. $\mathrm{O}$ argumento da escola se resumia no fato de a família ou de o próprio jovem e/ou adulto, sem deficiência, ter desinteresse em estudar nesta sala, quando percebia o número elevado de pessoas com deficiência no seu interior. Dos 11 alunos matriculados, apenas um era considerado alfabetizado e os outros 10 eram alunos em processo de alfabetização, apesar de três destes ainda serem considerados alunos fracos.

As atividades propostas aos alunos, nesta manhã, resumiram-se em copiar, no caderno, o cabeçalho dado no quadro (nome completo da escola, cidade e data, nome do aluno e da professora); fazer atividades formais de matemática, tais como escrever os números pares de um até 40 e resolver "continhas" $10+5 ; 8+6 ; 7+9 ; 12+8 ; 15+7$ e trabalho com massinhas coloridas para que os alunos pudessem desenvolver sua criatividade, modelando 
alguma coisa que fosse do interesse deles. Nas atividades envolvendo operações, os alunos utilizavam muitos materiais concretos, tais como tampinhas de garrafa, bolinhas e pauzinhos de picolé. Como tarefa de casa foram dadas mais continhas. Tudo era registrado diariamente no Diário de Classe. No decorrer do recreio, os alunos não demonstraram nenhum tipo de entrosamento com os demais colegas no pátio, ficaram à margem do contexto escolar.

Na leitura realizada, concebeu-se que, neste dia, essa sala funcionou de forma tradicional em tudo: conteúdo, material didático, metodologia, distribuição de carteiras (apesar do pequeno espaço físico), utilização do quadro, do diário, dos cadernos... Não foi percebido nenhum tipo de inovação que pudesse ser descrita como destaque e que justificasse a sua criação. Apesar da assistência, das orientações individuais e da preocupação com todos os alunos, a professora demonstrou não estar mobilizada para mudanças relacionadas com sua prática pedagógica ou com qualquer outro tipo de transformação em sua sala de aula.

Na SAEJA II, todos os alunos tinham algum tipo de deficiência e situavam-se na faixa etária entre 10 e 18 anos de idade. Nesta sala, algumas situações foram classificadas como inaceitáveis: os alunos não se respeitavam, gritavam o tempo todo, ofendiam uns aos outros por meio de palavras e até se agrediam fisicamente. E a atitude da professora diante desta situação? A impressão causada foi a de que ela não conseguia impor limites aos seus alunos, pois os comportamentos estereotipados se repetiam com frequência. Ela se limitava a vigiar os alunos e dar assistência aos "mais fracos", adotando uma postura paternalista, sem demonstração de compromisso pedagógico. Não foi observada nenhuma atividade interessante selecionada, iniciativa ou criatividade para a mudança do contexto pedagógico da sala de aula. Um fato que também chamou a atenção foi a presença de uma criança com idade inferior a 10 anos nesta sala. Daí a indagação: os critérios para se frequentar esta classe não estão sendo seguidos? Por quê? Pelos documentos das SAEJA, a idade mínima para que se possa frequentá-las é de 12 anos, como exceção e se for extremamente necessário. O que justificaria então o ingresso de crianças nesta sala direcionada a jovens e adultos e ainda em uma escola "inclusiva e de referência"?

Os alunos de outra dessas salas observadas, denominada III, eram todos adultos com idade entre 21 e 56 anos. O espaço físico da sala de aula se diferenciava das demais desta escola por ser bem menor, inclusive para acomodar os 14 alunos presentes. Apesar de os alunos em geral demonstrarem interesses similares em diversos assuntos, o trabalho realizado pela professora 
era individualizado: os alunos eram atendidos isoladamente, sem trocas de experiências ou ajudas entre eles. As atividades eram descontextualizadas e sem sentido para um adulto. Moças e donas de casa faziam atividades de coordenação motora sem nenhuma articulação com conteúdos interessantes e copiavam numerais (de 1 a 5) sem sentido expresso e também totalmente de forma descontextualizada. Concebe-se que, apesar de todo o interesse e carinho demonstrado pela professora em sala de aula, o trabalho realizado com os adultos deveria ser muito diferente, mais condizente com sua realidade, mais estimulante e com maior compromisso pedagógico. Mais uma vez foi demonstrado que as atitudes paternalistas/assistencialistas por parte dos professores nestas SAEJA têm sido constantes.

Não se pode negar a importância de se estabelecer mecanismos e instrumentos que assegurem às pessoas o pleno exercício de seus direitos básicos que proporcionem o seu bem-estar pessoal, social, econômico e humano, seja ela uma pessoa com necessidades educativas especiais ou não (ALMEIDA e TEIXEIRA, 2011).

A situação foi ainda muito mais séria em uma SAEJA, denominada IV, em que, praticamente, todos os seus alunos eram jovens com grandes possibilidades de aprendizagem, inclusive com dons artísticos elevados. Mas como estavam em um ambiente segregado de uma Escola Inclusiva de Referência (EIR), a descrença dos profissionais da escola como um todo em relação ao aprendizado deles pareceu ser total.

Entende-se que todos esses alunos deveriam ser conduzidos para as turmas seriadas da própria escola ou para as salas de Educação de Jovens e Adultos/EJA da própria rede estadual, que na ocasião nada as ligava com as SAEJA, para minimizar os possíveis danos causados pela escola a estes jovens. Acredita-se que os atos de indisciplina, assim como os comportamentos estereotipados que foram presenciados, poderiam ser evitados se os alunos convivessem em um ambiente "normal", menos estigmatizante e segregado.

Alguns alunos com dificuldades de aprendizagem demonstraram, até mesmo, rejeição pela turma que frequentavam e, sobretudo, pelos próprios colegas mais comprometidos intelectualmente. Houve diversas demonstrações de que eles se sentiam envergonhados por estar ali, o que era completamente compreensível.

Em vista dessa situação, por exemplo, na qual há alunos com habilidades para artes, questiona-se se os estudos sobre a Teoria das Inteligências Múltiplas, considerados de grande importância para os Setores de Apoio à Inclusão da SUEE/SEE, estavam sendo levados em conta nas práticas pedagógicas desenvolvidas em sala de aula. Constatou-se naquele contexto que não! 
Essa Teoria - produzida por Gardner em 1983 e aperfeiçoada por Armstrong em 1987, 1994 e 1996 - proporciona uma estrutura útil para a identificação de estratégias de ensino em multiníveis, com base nas áreas que a constituem: Inteligência Linguística, Inteligência Lógico-Matemática, Inteligência Espacial, Inteligência Corporal-Cinestésica, Inteligência Musical, Inteligência Interpessoal, Inteligência Intrapessoal e a Inteligência Naturalística.

Se as aulas, nessas salas alternativas, fossem fundamentadas na Teoria das Inteligências Múltiplas, com certeza, os professores teriam, como nos afirmam Stainback e Stainback (1999, p. 148), "maior chance de obter êxito no ensino de todos os seus alunos, incluindo aqueles que foram classificados e rotulados como tendo diferenças e deficiências, como estando sob risco ou como difíceis de ensinar".

No decorrer de toda a aula, nesta sala, apesar das dificuldades encontradas, a professora demonstrou interesse por todos os alunos e conseguiu desenvolver algumas atividades interessantes, estimulantes e criativas. Em seu depoimento, entretanto, declarou sentir-se abandonada e sem apoio. Ela declarou, inclusive, não concordar com o funcionamento da SAEJA, entendendo-a como segregadora, especialmente por se encontrar no interior de uma escola inclusiva.

Todos os alunos de outra SAEJA denominada $\mathrm{V}$, tinham algum tipo de deficiência e se situavam na faixa etária entre 14 e 30 anos. Observou-se com estranheza o descompromisso pedagógico demonstrado pela professora diante dos seus alunos. Em seus depoimentos, evidenciou-se que aqueles alunos estavam no lugar certo, pois "em sala regular, ninguém vai dar conta de muita coisa". Ela acreditava que os alunos ali presentes, assim como outros, precisam ser "bem preparados" por professores que entendem o ensino especial, como ela, para que sejam incluídos no ensino regular.

As atividades trabalhadas nesta SAEJA foram bem recebidas pelos alunos, talvez por acomodação, pois não traziam qualquer tipo de dificuldade ou desafio. Os alunos diziam o que queriam fazer e eram atendidos de imediato pela professora, ninguém era contrariado ou estimulado a inovações.

Esta realidade observada remete mais uma vez às concepções de integração escolar vigentes nas décadas de 1970 e 1980 que continuam fazendo parte do ideário de muitos professores, mesmo entre aqueles que se encontram em escolas consideradas inclusivas: apenas o aluno precisa ser preparado e modificado para se adequar à escola, a culpa é totalmente dele, caso contrário, jamais sairá do estado de marginalização em que se encontra.

Na última SAEJA observada, denominada VI, a situação não foi alterada. Estavam presentes 16 alunos, dos quais 15 tinham algum tipo de 
deficiência. Encontravam-se na faixa etária entre 12 e 19 anos de idade, excetuando-se dois, com 39 e 51 anos. Praticamente todos esses alunos eram egressos de escolas ou classe especiais. $O$ único aluno estudante sem qualquer tipo de deficiência era um senhor com mais de 50 anos de idade tratado como criança, executando as atividades escolares junto a adolescentes e jovens entre 12 e 19 anos!

Pelo que foi afirmado pela coordenadora da escola, houve continuidade do ensino especial para o atendimento dos alunos jovens e adultos com deficiência nesta escola, mas em outra modalidade, agora, sob a denominação de Sala Alternativa de Educação de Jovens e Adultos (SAEJA). Esta afirmação pôde ser constatada em cinco das seis SAEJA observadas neste estudo.

\section{TENTANDO NÃO CONCLUIR, MAS PENSANDO NO FUTURO...}

Percebe-se que a criação dessas salas continuou discriminando, segregando e excluindo alunos, apesar do discurso contrário da SUEE/SEE; as SAEJA contradizem a proposta de inclusão por ser uma modalidade especial para atender a pessoas que histórica e culturalmente já tinham uma longa experiência de discriminação e marginalização no meio escolar. Isso a partir de 12 anos de idade!

Como não se verificou nas seis salas observadas, praticamente, nenhum trabalho pedagógico escolar definido e sistematizado voltado para o atendimento adequado de alunos jovens e adultos, não se pode tecer comentários a respeito da sua proposta curricular. Os professores destas salas pareciam estar fazendo o que podiam e o que sabiam, pois se sentiam comprometidos com os alunos, muito mais por questões pessoais e paternalistas do que por questões pedagógicas. Mas isso seria suficiente? A maioria destes professores havia atuado em classes especiais que funcionavam nessas mesmas escolas antes de se tornarem EIR e com os mesmos alunos que não foram incluídos nas turmas escolares regulares. $\mathrm{O}$ que mudou?

Para os professores dessas salas, nem a SUEE nem a SEADEC assumiam as SAEJA de forma sistematizada; havia ali um verdadeiro jogo de empurra-empurra.

Para entender e conhecer melhor a proposta das SAEJA, idealizada pela SUEE, dois assessores deste órgão foram entrevistados e afirmaram que

estas salas foram criadas para dar mais oportunidades aos alunos jovens e adultos com deficiência de se escolarizarem, por não terem tido oportunidades de estudar em escola regular na idade escolar. 
Segundo esses assessores, as SAEJA deviam seguir as mesmas diretrizes da SEADEC e adotar estratégias para atender às necessidades dos alunos especiais. Nas palavras desses assessores, "proposta alternativa não é para ficar para sempre, é uma transição para ser trabalhada junto". Para eles, as SAEJA se justificam pelo fato de as salas de jovens e adultos da SEE serem muito cheias, funcionarem no período noturno e sofrerem muita resistência dos profissionais de educação em trabalhar com alunos com deficiência.

A SUEE pretendia, na ocasião, capacitar os professores das salas de jovens e adultos para trabalhar com os alunos que têm dificuldades. Para tanto, buscaria parcerias e envolvimento da SEADEC. No futuro, a SUEE, segundo seus assessores, espera que os alunos das salas alternativas possam ser encaminhados para outros programas da SEE, como o Supletivo ou o Acelera.

Numa tentativa de obter maiores esclarecimentos a respeito das SAEJA, procurou-se uma assessora da SEADEC. Em conversa informal, ela afirmou que as SAEJA são uma "invenção" do ensino especial e que elas não têm nada a ver com o Programa de Jovens e Adultos desenvolvido pela Superintendência de Ensino a Distância e Educação Continuada.

Diante dessas constatações, as responsabilidades e os compromissos com os alunos jovens e adultos com necessidades educativas especiais, por parte dos gestores responsáveis por essas salas, ficavam difíceis de serem expressos.

O depoimento de uma das diretoras da escola onde foi implantada uma SAEJA evidencia o descaso por estas salas, ao afirmar que todos os problemas detectados são tanto de ordem institucional quanto operacional, em virtude das diretrizes equivocadas da SUEE e das indefinições da SEADEC. Ela afirmou ainda que,

na verdade, nenhum órgão da SEE quer assumir esta sala. Ela só existe por insistência dos pais e da própria escola que não tem onde colocar os alunos deficientes que não acompanham as salas regulares.

Com este depoimento, constataram-se uma vez mais as dificuldades que as EIR têm de compreender como a inclusão deve ser operacionalizada, apesar de tantos cursos e tantas orientações terem sido repassadas pelo ensino especial.

A inclusão requer mudanças sistemáticas na maneira como as escolas são organizadas e administradas, há necessidade de alterações envolvendo, sobretudo, a comunidade escolar. Trabalhar com a diferença, no sentido pleno, é entender que o ensino, o apoio, os recursos didático-pedagógicos, a metodologia, a proposta curricular e a própria avaliação da aprendizagem devem beneficiar a todos e não apenas a"alguns". É preciso enfrentar o desafio 
de trabalhar com as diferenças para atender a diversidade que se faz presente nas escolas em geral.

As dificuldades das EIR também ocorrem quando se solicita qualquer tipo de apoio para as SAEJA, pois não se sabe claramente quais são os verdadeiros responsáveis por elas. Enquanto as orientações e diretrizes de atendimento aos alunos e professores são dadas pela SUEE, a SEADEC, que deveria ser a responsável institucional por essas salas, cala-se e se omite completamente.

A única inovação trazida pelas $S A E J A$, em relação às classes especiais, foi o fato de se direcionarem (ainda que no papel) apenas a jovens e adultos, mas nelas constatamos a presença de alunos com 12 anos de idade e com o respaldo do próprio ensino especial. Por que 12 anos se a idade limite para a matrícula no Ensino Fundamental ainda é de 14 anos? E na EJA a partir dos 15 anos?

Ressalta-se, por contradição, que também havia um sentimento de aprovação, nas escolas pesquisadas, em relação à criação das SAEJA, pois elas constituíam uma das opções das escolas para os alunos considerados "difíceis" de serem incluídos, segundo alguns de seus diretores, coordenadores e professores, em razão da imaturidade, idade cronológica avançada, do nível acadêmico deficitário e comportamento inadequado.

Enfim, há sempre uma alternativa de se resolver os problemas dos alunos jovens e adultos com necessidades educativas especiais, mesmo em uma escola que se diz inclusiva e com a aprovação da Secretaria de Estadual de Educação, que insiste em afirmar, em seus discursos, a integração de todos os seus programas escolares.

Entende-se que se houvesse uma melhor articulação e integração entre os órgãos da Secretaria Estadual de Educação de Goiás seria possível a transformação da política educacional de atendimento aos jovens e adultos, para que todos pudessem ser beneficiados, sem alternativas que acabam se constituindo em discriminação, marginalização, e, em consequência, exclusão de toda ordem.

A situação de exclusão em que se encontram muitos jovens e adultos, com necessidades educativas especiais ou não, é histórica e cultural. Apesar de alguns avanços nesse sentido, sobretudo graças à ação de grupos populares, de organizações não governamentais e de profissionais comprometidos com a área, a educação desses alunos no Brasil ainda continua sendo um verdadeiro desafio para as nossas políticas de governo e, inclusive, públicas. A este respeito, Soares (1999, p. 30) assim se pronuncia: 
A educação de jovens e adultos é um conceito mais ampliado, mais próximo da realidade da população que a demanda. Não se trata de mera transmissão de conhecimentos nem de projetos aligeirados com vistas à rápida aquisição do diploma. Educação é processo, é conhecimento, é reflexão, é interação, que requerem 'tempo' e 'espaços' para serem vivenciados.

Rodrigues (2000) complementa essa concepção ao esclarecer que a Educação de Jovens e Adultos deve ser compreendida como direito público subjetivo de todo cidadão a uma educação de qualidade ao longo da vida, como um bem sócio-histórico e culturalmente produzido, com finalidades e funções específicas, que precisa efetivar a função reparadora da dívida histórica-social com aqueles que não tiveram acesso à educação ou dela foram excluídos, bem como contemplar as funções equalizadora e qualificadora. Trata-se de uma educação que respeite as características dos sujeitos a que se destina, enquanto modalidade, com formas de organização adequadas às suas necessidades e disponibilidades, garantindo-se o acesso e a permanência aos alunos trabalhadores, e compete ao Estado o dever de oferecer as condições necessárias para a execução desta modalidade de ensino.

A concepção que permeou toda a pesquisa realizada partiu do princípio de que toda ação educativa deve ter como eixo o convívio com as diferenças, a aprendizagem como experiência relacional, participativa que produz sentido para o aluno, pois contempla a sua subjetividade, embora construída no coletivo das salas de aula.

A inclusão, como nos esclarece Mantoan (2002, p. 86), "é um conceito que emerge da complexidade, dado que a interação entre as diferenças humanas, o contato e o compartilhamento dessas singularidades compõem a sua ideia matriz".

Concretizar, de fato, a inclusão de pessoas com necessidades especiais, quer seja com crianças, jovens ou adultos, conforme afirmação que tem sido feita frequentemente por Almeida (2003) constitui um grande desafio, pois envolve mudanças na concepção de sociedade, de homem, de educação e de escola. Mudar concepções já cristalizadas e arraigadas em nome de outro modelo de educação não é uma tarefa simples e fácil, sobretudo quando essas mudanças vão beneficiar pessoas que foram historicamente injustiçadas, marginalizadas e excluídas da sociedade, e, em consequência, da escola. 


\section{REPORTS ON 'ALTERNATIVE CLASSROOMS FOR YOUTH AND ADULT EDUCATION' FOR PEOPLE WITH SPECIAL EDUCATIONAL NEEDS: A LOOK INTO THE PAST WITH AN EYE TO THE FUTURE}

ABSTRACT: This article discusses the alternatives adopted by the Goiás State Education Network at the beginning of this century for the care of young people and adults with special educational needs. The discussion is based on qualitative research of a descriptive and reflexive nature in which observation techniques, interviews and documental analyses were used as data collecting tools. It sets out to analyze how the 'Alternative Classrooms for Youth and Adult Education' were structured and organized to support people who had been historically marginalized and excluded from the Brazilian educational system because they did not meet its requirements. Among its conclusions, the study highlights State government indifference towards this target group, particularly in terms of the education of young people and adults with special educational needs, whether intellectual, sensorial or physical, who are still on the sidelines when it comes to adequate quality education.

KeYwords: Alternative classrooms. Young people and adults. People with special educational needs.

\section{REFERÊNCIAS}

ALMEIDA, Dulce Barros de. Do especial ao inclusivo? Um estudo da proposta de inclusão escolar da rede estadual de Goiás, no município de Goiânia. Tese (Doutorado em Educação), Faculdade de Educação, Universidade Estadual de Campinas, Campinas: SP, 2003.

ALMEIDA, Dulce Barros de; TEIXEIRA, Ricardo A. Gonçalves. Contexto educacional complexo e diverso a partir de uma análise interpretativa dos aspectos legais que subsidiam propostas educativas inclusivas. In: SUANNO, Marilza V. Rosa (Org.). Didática e escola em uma sociedade complexa. Goiânia: CEPED, 2011.

BRASIL/MEC. Lei de Diretrizes e Bases da Educação Nacional, Lei n. 9.394. Brasília/ DF, 1996.

BRASIL/MEC/SEESP. Resolução CNE/CEB n. 2. Diretrizes Nacionais para a Educação Especial na Educação Básica. Brasília/DF, 2001.

GOIÁS/SEE/SUEE. Projeto Diversidades: uma alternativa inclusive para a educação de jovens e adultos com necessidades especiais. 2000 (mimeo).

LAJONQUIÈRE, Leandro de. Duas notas psicanalíticas sobre as crianças com "necessidades educativas especiais". In: Pro-posições, v. 12, n. 2-3, p. 35-36, jul./nov. 2001. Revista Quadrimestral da FE/Unicamp. p. 47-59.

MANTOAN, Maria Teresa. Eglér. Produção do conhecimento para a abertura das escolas às diferenças: a contribuição do LEPED (Unicamp). In: ROSA, D. E. G.; SOUZA, V. C. 
Políticas organizativas e curriculares, educação inclusiva e formação de professores - XI ENDIPE. Rio de Janeiro: DP\&A e Goiânia: Alternativa, 2002. p. 79-93.

RODRIGUES, Maria Emilia de Castro. A Prática do Professor na Educação de Adolescentes, Jovens e Adultos: a experiência do Projeto AJA de Goiânia-GO. Goiânia, GO, 2000. Disponível em: http://forumeja.org.br/go/sites/forumeja.org.br.go/files/dissertacaomariaemilia.pdf. Acesso em: 30 jul. 2011.

SOARES, Leôncio José Gomes. Processo de inclusão/exclusão na educação de jovens e adultos. In: Revista Presença Pedagógica. Editora Dimensão, v. 5, n. 30, nov./dez. 1999. p. 24-33.

STAINBACK, Susan; STAINBACK, William. Inclusão- um guia para educadores. Trad. de Magda França Lopes. Porto Alegre: Artes Médicas Sul, 1999.

Dulce Barros de Almeida iniciou suas atividades como docente em 1972, junto a crianças, jovens e adultos acometidos por algum tipo de deficiência, em Belo Horizonte/MG. É licenciada pela PUC/Minas; Especialista em Educação Especial pela PUC/GO; Mestre em Educação Escolar Brasileira pela FE/UFG e Doutora em Educação pela Unicamp/SP. Atua nas áreas de Didática e Estágio, Metodologia do Ensino Superior, Educação Especial e Inclusão Escolar. Atualmente desenvolve suas atividades como professora colaboradora do Programa de Pós-Graduação da FE/UFG (Mestrado e Doutorado) na Linha de Pesquisa - Formação e Profissionalização Docente; como Pesquisadora vinculada ao Diretório de Pesquisa da Unicamp - Laboratório de Estudos e Pesquisas em Ensino e Diversidade - LEPED, desde 1999 e como coordenadora do Núcleo de Acessibilidade da UFG a partir de setembro/2011.

Email: dubalmei@hotmail.com 



\title{
LIMITES SOCIAIS DAS POLITICAS DE EDUCAÇÃO: EQUIDADE, MOBILIDADE E ESTRATIFICAÇÃO SOCIAL*
}

\author{
FERNANDO TAVARES JúNIOR, \\ da Universidade Federal de Juiz de Fora
}

\begin{abstract}
REsumo: A esperança moderna de equalização de oportunidades por meio da democratização de sistemas públicos de ensino encontra limites sociais para efetivar-se. A tese de Hirsch (1979) aplica-se ao caso, especialmente em períodos de democratização. A expansão do acesso às credenciais educacionais tende a deslocar sua desigualdade para estratos horizontais (COLLINS, 1979). À medida que expande numericamente, os efeitos sociais da educação tendem a perder sua qualidade e seu poder social. Antes, um mecanismo moderno de mobilidade ascendente, com baixa dependência da origem social, a educação perde características de equidade sem superar mecanismos reprodutores da desigualdade. A análise crítica deste modelo de expansão de matrículas aponta para a reavaliação de seus objetivos e mecanismos de construção democrática.
\end{abstract}

Palavras Chave: Sociologia da Educação. Ensino Superior. Mobilidade Social. Classes Sociais.

\section{APRESENTAÇÃo}

A esperança moderna de equalização de oportunidades através da democratização de sistemas públicos de ensino encontra limites sociais para efetivar-se. $O$ século XX foi marcado, no Ocidente, pela ampliação dos direitos sociais, dentre eles a educação, mesmo que tardiamente em países em desenvolvimento, como o Brasil. Aqui, o ensino médio e superior foram os níveis que registraram maior expansão nas últimas décadas, superadas as

\footnotetext{
* Artigo recebido em 20/07/2011 e aprovado em 20/09/2011.
} 
maiores barreiras de reprovação e evasão impostas pelo Ensino Fundamental, antigo $1^{\circ} \mathrm{grau}$. Esse conjunto de transformações elevou o nível médio de escolaridade da população, ainda que, em comparação com países mais ricos, esse indicador permaneça baixo. Por outro lado, as décadas de 1980 e 1990 também foram marcadas pelo baixo crescimento econômico, que levou à retração do emprego formal, consequências também do processo de globalização e de reestruturação produtiva.

Apesar de amplo conhecimento produzido a respeito das transformações ocorridas no Brasil neste período, não se sabe exatamente qual foi o poder efetivo do sistema de ensino em operar mudanças sociais, a despeito de sua larga expansão nas últimas décadas. Também não se sabe seu poder relativo, quando comparado a outros elementos sociais. Há correntes na sociologia que tendem a enxergar o sistema de ensino, mesmo em períodos de expansão e democratização, como mecanismo reprodutor ou pouco efetivo na mudança da estrutura social. De outro lado, há quem defenda o extremo oposto e outorgue à educação um grande poder de modernização social e equalização de oportunidades. Se, de um lado, a educação é vista como capaz de promover mudanças que proporcionem à sociedade melhores resultados de desenvolvimento econômico e social, por outro lado, a expansão do acesso a níveis mais elevados de educação não tem se mostrado eficiente para diminuir as desigualdades sociais e diminuir o desemprego. Entre os dois polos propõem-se lançar luz sobre o poder e o limite social da educação.

Em From school to work, Shavit e Muller (1998) organizam, em perspectiva comparada, a análise de 26 autores acerca das relações e mediações entre a escola e o mundo do trabalho nos dias atuais. Os estudos compilados no livro mostram tanto que a educação tem perdido poder de realização social, quanto que este poder está diretamente ligado à forma de estruturação dos sistemas de ensino. Sistemas com direcionamento (tracking) a terminalidades mais curtas (ensino técnico profissionalizante em níveis básicos) tendem a garantir maior poder social (emprego, renda, status) à obtenção de credenciais elevadas. O ensino superior não produz, nos países investigados, ${ }^{1}$ um grande efeito estratificador como o registrado em décadas anteriores, ${ }^{2}$ mas permanece importante seu papel de prevenção do desemprego. A estratificação educacional tende a estar cada vez mais nivelada nos níveis médio e superior, tendendo, então, a uma diferenciação por carreiras e por instituições mais do que por anos de escolaridade, ou seja, uma estratificação mais horizontal do que vertical.

É importante observar também que essa conclusão encontra paralelo com o estudo de Jackson e Goldthorpe (2002) acerca dos mecanismos de 
seleção empreendidos na Inglaterra e que também revela horizontalidade da competição entre credenciais e, mais ainda, a externalização da competição e das credenciais, ou seja, a diferenciação através de credenciais obtidas fora do sistema regular de ensino. Isso configura um duplo sistema credencialista e produtor de estratificação via qualificações. Essa duplicidade sempre existiu, entretanto, agora ela começa a operar de forma sistêmica e em competição e/ou simbiose com o sistema educacional.

De outro lado, o poder de realização social (emprego e salários) está também ligado à forma do sistema que, por sua vez, está ligada à forma de construção societária típica de uma determinada sociedade. Este pode configurar um dos exemplos da ação social como categoria produtora de diferenciações sociais no modus operandi do capitalismo, como observaram Erickson e Goldthorpe, em The Constant Flux (1993). De certa forma, por uma via, o capitalismo subsume as estruturas e o modo de funcionamento social e, por outra via, a própria sociedade e seu modo de ação social subsumem o modus operandi destas estruturas, gerando formas típicas e mistas entre o capitalismo e a cultura. Uma vez que a obra traz estudos em diversos países, foi possível observar o delineamento de três blocos. Um modelo é mais liberal e ligado à matriz anglo-saxônica, com Estados Unidos, Inglaterra e Austrália, em que as oportunidades educacionais são mais abertas, um maior percentual da população atinge o ensino superior, o sistema é menos dual, mas também é o que oferece o menor poder de realização social posterior.

Na outra ponta, há o modelo germânico (Alemanha, Suíça etc.), mais dual e seletivo, mas que obtém muito maior poder de realização e no qual o ensino superior torna-se praticamente uma salvaguarda contra o desemprego. Entre os dois há um modelo misto, como o francês, em que há dualidade e seletividade, mas ao mesmo tempo menos rigidez; ou o modelo sueco, em que há grande relação entre os poderes públicos, privados e organismos da sociedade civil. $\mathrm{O}$ argumento da influência da ação social na modelagem de sistemas educacionais e seus resultados será aprofundado posteriormente.

Por hora, importa destacar o modelo defendido por Goldthorpe (2000), inspirado em Boudon (1979), que destaca a importância da tomada de decisão individual, do ethos e da análise de custo e benefício da educação como investimento pessoal e familiar para analisar o potencial de realização educacional em cada contexto. Para Goldthorpe, ao contrário do que defendem teóricos liberais, faltam evidências de que a redução de diferenças educacionais entre classes gerou os resultados esperados, se comparados às expectativas geradas. Ele critica também, de outro lado, a teoria da "reprodução cultural" de Bourdieu, ao constatar que: 
against Bourdieu, educational expansion implies not reproduction of cultural capital but rather its very substantial growth [...] In other words, proponents of theories of cultural reproduction would appear to be betrayed by their rather gross misunderstanding of the degree to which in modern societies opportunities for upward educational - and also class - mobility between generations have indeed been enlarged and exploited. (GOLDTHORPE, 2000 p. 169)

Goldthorpe concorda com o argumento de Boudon (1979) ao defender que as similaridades na estrutura social não seriam decorrências apenas da reprodução estrutural, mas de como se dão as escolhas e como se processam as relações de custo/benefício para cada classe. Para Boudon, se a estrutura social permanece estável, a ampliação de diplomas significa degradação das oportunidades, o mesmo raciocínio de Hirsch (1979), que também se aplica ao caso, especialmente em períodos de democratização.

Acerca da relação entre educação e realização social, a revisão do Relatório Coleman (1966) pode ser um dos pontos de partida para traçar um panorama teórico, a elaboração de políticas e um marco para as investigações empíricas posteriores. A tese de Coleman, e aceita ainda hoje, é que estão na família e nas condições sociais herdadas os principais fatores que motivariam o sucesso. Sua conceituação de capital social aproxima-se do "capital familiar", tendo em vista um conjunto de recursos materiais e imateriais agregados no grupo familiar e que são repartidos pelos filhos e, portanto, limitados pelo seu número numa razão inversamente proporcional: quanto mais filhos, menor a capacidade de investimento e menor a realização social futura da prole, como a mobilidade social. Importa destacar que essa lógica é derivada de um modelo anglo-saxão liberal, em que a família é a principal e quase única responsável pelo investimento nos jovens, em especial, do ensino superior.

Essa distinção é central porque enquanto a tradição anglo-saxã foi de investimento privado nos níveis mais elevados de ensino, notadamente no ensino superior, a tradição latina foi a de maior participação estatal neste tipo de investimento, algo historicamente também verificado no Brasil. Entretanto, a recente expansão do ensino superior no Brasil tem seguido padrões mistos de ampliação das instituições privadas, mas sem deixar de haver vínculos estatais muito fortes, seja nos benefícios fiscais, no financiamento de bolsas através do Fundo de Financiamento ao Estudante do Ensino Superior (FIES) ou do Programa Universidade para Todos (Prouni). Mais uma vez, este campo é atravessado por elementos de "modernização conservadora". 
EDUCAÇÃO E MOBILIDADE: UMA ANÁLISE DA BIBLIOGRAFIA

A inflação educacional seria economicamente dispendiosa e socialmente contraproducente por gerar frustrações decorrentes das expectativas e crenças socialmente partilhadas. Quando todos se veem forçados a permanecer nesse círculo vicioso, deixa-se o "efeito perverso". Todavia, essa lógica foi contestada por Andorka (1976), quando aplicou o modelo de Boudon aos dados da Hungria. Parece que quanto mais aberta é a sociedade, menos ela padece desses efeitos perversos. Bourdieu (2000) apresenta argumento inverso, coerente com a tese da reprodução social, via herança de capital cultural, contudo, não utiliza uma base de análise individual, mas de classe, a partir do conceito de habitus. Para Bourdieu (2000), apesar de movimentos singulares de mobilidade, os estudos de mobilidade social na forma tradicional devem ser contestados em razão de não observarem os chamados efeitos de trajetória. As frações de classe mais afetadas por mudanças no sistema educacional seriam aquelas que apresentam a organização da estrutura do capital sob a espécie cultural, o que será aprofundado posteriormente.

Nesses casos, em concordância com Hirsch, a ampliação da rede escolar forçaria sempre o aumento do consumo educacional (consumo defensivo) para manter o efeito de distinção. Para quem busca mobilidade por meio da educação, a obtenção de títulos acontece já com a depreciação de seu valor. Ainda que em condições iguais, aquele que acumulasse mais capital sob outras espécies (social e econômico) conseguiria ter sucesso. Daí a lógica da reprodução, da expansão homogênea das matrículas como desperdício social ou "limite social da educação" por se mostrar impotente para realizar as expectativas planejadas (HIRSCH, 1979).

Outra consideração diz respeito ao fechamento social. Uma sociedade é mais fechada quanto menos sua elite é permeável à entrada de membros oriundos de estratos mais baixos. Quanto mais fluida se apresentar a estrutura de entrada nas diferentes classes, notadamente nas mais altas, mais aberta é a sociedade. Quanto mais uma determinada estrutura social é "fechada", mais limitado é o poder da educação. Este argumento está ligado à abertura e ao fechamento social, articulado por Murphy (1988), em que são avaliadas as condições sociais e as possibilidades de maior ascensão rumo à elite (mobilidade de longa distância), e sua relação com a educação. Quanto maior é o fechamento, menor é a probabilidade de se chegar à elite, logo de se realizar mobilidade de longa distância. Entretanto, um modelo social fechado não parece ser o caso do Brasil, e mesmo assim a mobilidade longa é exceção. A educação então, de alguma forma, parece não estar conseguindo 
cumprir um papel relevante se considerado o seu potencial em razão das condições de abertura.

Titma, Tuma e Roosma (2002) investigaram a educação como fator de mobilidade social na União Soviética. Para os autores, a educação como um fator de mobilidade intergeracional em si não pode ser visto como uma tendência ligada à meritocracia. Na sociedade em que os objetivos dominantes são políticos e não econômicos, e a liberdade individual para construir a própria vida é limitada, a mobilidade intergeracional pode ser influenciada pesadamente pelo Estado. Assim, a educação é uma circunstância apenas parcialmente ligada ao mérito. Jackson, Goldthorpe e Mills (2002) constataram, empiricamente, a insuficiência da teoria liberal em entender como se desenvolvem processos de mobilidade social através da educação. Desenvolvendo análises a partir das bases já citadas do trabalho de Jackson em anúncios de emprego em jornais, os autores assinalaram uma tendência contra a teoria liberal (Meritocracia e Teoria do Capital Humano) muito forte, durante décadas. As qualificações educacionais diminuíam sua importância em processos de mobilidade.

Outro trabalho relevante sobre mobilidade e ensino superior é o de Louis Chauvel (1998), em que são analisadas coortes educacionais na França. As mudanças na dinâmica do mercado de trabalho, interferindo no ritmo do desenvolvimento educacional, produziram uma evolução do valor medido pelas chances de acesso a posições sociais diferentes, a partir de diferentes coortes. Foi observado, na França, um declínio progressivo do valor dos níveis escolares (graus) pela população nascida depois de 1950 (inflação de credenciais). As consequências da dinâmica histórica da educação e o valor de cada grau tendem a afetar tanto as chances para achar uma posição nas categorias sociais mais altas, quanto as chances para desfrutar uma mobilidade intergeracional ascendente. Martin Gross (1998) apresenta importante contribuição ao pesquisar sistemas educacionais, mobilidade intrageracional e desigualdade social percebida. Revelou que o papel da educação de alocar as pessoas em ocupações difere entre sociedades. O valor de títulos educacionais para arrumar um emprego depende da estrutura do sistema educacional. Foram avaliados títulos educacionais em países que apresentam um sistema educacional altamente unificado, estratificado e diferenciado. São chamados "países credencialistas", significando que aqueles títulos educacionais são úteis como meios de exclusão. O paper corrobora as hipóteses de que: (1) a associação global entre educação e classe é mais forte em países credencialistas, que em alguns casos se aproxima do Brasil, como observa Schwartzman (2001); (2) é possível distinguir tipos diferentes de 
credencialismo de acordo com a estrutura dos vários sistemas educacionais que conduzem a estruturas de classe específicas. Por exemplo, em países com um sistema educacional altamente diferenciado verticalmente, a divisão entre manual e não manual são pronunciadas. Entretanto, o paper refuta a hipótese de que (3) os títulos educacionais são mais importantes por alocar as pessoas a trabalhos e menos importante seriam características de indivíduos e mercados de trabalho. Se a associação entre educação e posição de classe pode estar perdendo força, é provável que seja porque a educação está perdendo o seu valor para empregadores. Isso foi defendido por papers ao mostrarem que a importância dada pelos empregadores às qualificações educacionais, em anúncios de trabalho, varia amplamente em relação a tipos diferentes de ocupação. Empregadores selecionam os empregados pela referência para qualquer atributo que eles acreditam ser pertinente à eficiência produtiva, e não há nenhuma garantia de que esses atributos sempre serão indicativos de mérito, como definido em condições de realização educacional ou realmente de qualquer outro modo plausível. Destacam também que construir uma alternativa viável à teoria liberal, que tem dominado assim o pensamento sobre educação e mobilidade de classe, pedirá um grande esforço teórico e de pesquisa.

No que tange à relação entre ensino superior e mobilidade, há, pelo menos, quatro estudos que configuram um diagnóstico do contexto no Brasil em micro e macroestrutura. O primeiro é a dissertação defendida por Maria Neli Cunha (1998) sobre mobilidade social e educação, em que o objeto central é o acesso a carreiras diferenciadas dentro do ensino superior. Observou-se clivagem de classe entre diferentes carreiras; a desigualdade tende a se reproduzir logo na porta de entrada das faculdades. Figueiredo (2006) também analisou o tema, com enfoque no financiamento do ensino superior e os resultados sociais das instituições privadas. Constatou que a educação superior é determinante, muitíssimo importante para a ascensão social no Brasil contemporâneo. Bastos (2004) analisou cursos de graduação e pós-graduação da Universidade Federal do Rio de Janeiro e observou que parece haver certa elitização no ensino superior brasileiro. Em relação à mobilidade social, verifica-se pequeno avanço entre estudantes de graduação, uma vez que eles já teriam uma determinada condição social de partida. Observa-se também clivagem de classe, com diferenças que aparecem entre os cursos em relação a essa questão. Outro estudo é o de Schwartzman (2003), baseado em dados do Instituto Brasileiro de Geografia e Estatística, em que o objeto é o acesso ao ensino superior no Brasil e o perfil dos estudantes, que verificou na década de 1990, ao mesmo tempo, a vertiginosa ampliação das 
vagas, que poderia representar a democratização, embora tenha verificado também a elitização do perfil.

De forma geral, todos observam a relação entre origem social e o destino projetado através da seleção entre diferentes carreiras. Isso reforça a tese de uma hierarquização dupla, tanto vertical (nível), quanto horizontal (carreira). De outro lado, observa-se também, através da Pesquisa Nacional por Amostra de Domicílios (PNAD), a progressiva elevação da desigualdade entre os egressos do ensino superior em virtude, especialmente, da distinção entre as carreiras. Para Schwartzman (2003), um dos principais objetivos do ensino superior no Brasil é proporcionar canais de mobilidade social para novos grupos sociais, além da formação de quadros com elevada qualificação para exercício profissional nos setores públicos e privados. Além disso, no Brasil, a relação entre escolaridade e renda é muito positiva e elevada, o que tende a agravar a desigualdade se não vencidos os gargalos do sistema de ensino. Entretanto, mesmo com a expansão das matrículas na educação básica e o vertiginoso crescimento do ensino superior na década de 1990, o quadro de desigualdade não se alterou e a expansão configurou um quadro de matrículas mais elitista do que o verificado no início da década. No processo de transformação de uma sociedade agrária e rural, para uma urbana e industrial,

higher education developed do provide channels of social mobility to new social groups, and train and educate new generations to fill the jobs in public and private sectors. [...] Brazil's income distribution, however, remains, one of the world's worst, and higher education may have contributed to this, by remaining limited to relatively few people and increase the weight of formal education and credentialism. A comparison of data from the National Household Surveys of 1992 and 2001 shows that growth in higher education was related to an increase in the proportion of students coming from the upper economic brackets, not a reduction. (SCHWARTZMAN, 2003, p. 20-21)

Diante disso, é preciso conhecer empiricamente os limites sociais da educação, em que situações têm se mostrado inócuos socialmente e, de outra forma, em que condições ou proporções eles se mostram socialmente tão úteis como propagado. De qualquer forma, o ensino superior é o nível de ensino que apresenta maior valorização econômica, maior dispersão e maior potencial para promover mobilidade social. Além disso, é o único com crivo de terminalidade e profissionalização, o que mais cresce no Brasil e com estratégias políticas que podem ser mais promissoras e, ao mesmo tempo, com "frustrações". 


\section{Metodologia}

Para testagem da relação entre origem e destino, foram produzidos modelos log-multiplicativos por nível educacional e sexo. Os modelos loglineares são tradicionalmente utilizados no Brasil para análise dos padrões de mobilidade social (Valle Silva, 1979 e 1999; Valle Silva e Pastore, 1998; Valle Silva e Hasenbalg, 2000 e 2003). São adequados para consideração do fenômeno sem as influências e/ou distorções dos efeitos marginais (como as diferenças na magnitude das classes de origem e destino), bem como pela explicitação adequada da força da relação entre origem e destino, uma das principais chaves para a compreensão dos padrões de mobilidade social. Os modelos log-multiplicativos (Unidiff), propostos por Xie (1992), mostram-se também adequados ao fenômeno, com a vantagem da consideração de efeitos em níveis, ou longitudinais, como é o caso dos dados em questão. A alteração da força da relação entre origem e destino ao longo do tempo, tomada em razão dos intervalos entre as diferentes edições da Pesquisa Nacional por Amostra de Domicílios (PNAD), é o objeto do estudo logmultiplicativo. Os dados foram produzidos de forma idêntica em diferentes PNADs (1973, 1982, 1988, 1996), em tabelas 9x9 (classes usuais de origem e destino), e acordo com o nível educacional (6) e o sexo (2). Acrescido o efeito

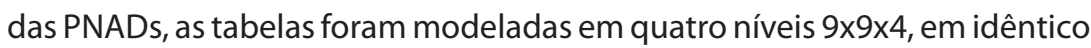
número: seis níveis educacionais e dois gêneros. Ao final, foram também produzidas tabelas com dados gerais por escolaridade e gênero.

Analisam-se, aqui, os efeitos da associação entre origem e destino em diferentes anos através do índice Kappa, ajustado para este tipo de estimativa em diferentes níveis nos modelos log-multiplicativos. Para tanto, utilizou-se aqui o software Stata 8.0 SE. Os modelos testados são modelo saturado, de independência, EGP tradicional, EGP ajustado para o Brasil, proposto por Ribeiro (2002) e o modelo multiplicativo de interação total. Foram consideradas três estatísticas de ajuste: BIC, G2, G2 ajustado ou G2b $(G 2 b=G 2-d f L o g N)$. A estatística que melhor se aplica à análise do ajuste do modelo aos dados é G2b; por isso, ela será a referência para a apresentação dos modelos no texto. Quanto menor é seu valor, melhor é o ajuste. Só são aceitos modelos cujo G2b é inferior a zero, uma vez que se mostra mais ajustado que o modelo saturado. Inicialmente, foram testados os modelos log-lineares nos diferentes anos. A Tabela 1 traz os dados de $\mathrm{G} 2 \mathrm{~b}$ para os diferentes anos, considerados para homens em todos os níveis de escolaridade.

Como se pode perceber, o modelo que mais se ajusta aos dados de mobilidade, nos diferentes anos, é o proposto por Ribeiro (2002), chamado aqui de "EGP Brasil", derivado do ajuste do modelo internacional de mobilidade 
derivado do padrão EGP, com 14 fatores característicos da mobilidade em países industrializados, e ajustado para o contexto nacional, que considera 12 desses fatores e acrescenta três outros típicos da realidade brasileira. Observa-se, também, que o ajuste melhora com o decorrer do tempo. Duas razões são importantes para a consideração deste ajuste. A primeira delas é a progressiva industrialização e seus efeitos sobre a sociedade brasileira, em especial a sua abertura a padrões e lógicas de mercado que aproximam seu padrão social ao de outros países industrializados que foram referências para a formulação do padrão EGP. O outro fator é o maior uso das PNADs de 1988 e 1996 para estudos deste tipo, favorecendo a melhor compreensão dos padrões de mobilidade nesses anos, o que tende a possibilitar um ajuste mais adequado a esses dados.

Tabela 1: Estatística de ajuste dos modelos log-lineares aos dados de mobilidade de homens entre 20 e 64 anos, para os anos de 1973/82/88/96.

\begin{tabular}{|l|c|c|c|c|}
\hline & \multicolumn{4}{|c|}{ G2b (G2-dfLogN) } \\
\hline Modelos / anos & 1973 & 1982 & 1988 & 1996 \\
\hline Saturado & 0,00 & 0,00 & 0,00 & 0,00 \\
\hline Independência & $20.434,79$ & $22.488,67$ & $11.623,94$ & $12.592,73$ \\
\hline EGP padrão & 136,74 & 251,16 & $-185,75$ & $-122,09$ \\
\hline EGP Brasil & $-28,38$ & $-141,17$ & $-270,20$ & $-232,26$ \\
\hline
\end{tabular}

Fonte: PNAD - IBGE.

Modelo: General Log-linear Model, proposto por Xie (1992) e adaptado aos dados brasileiros

Para a análise dos modelos log-multiplicativos, foram testados outros formatos, adequados a este tipo de análise. A melhor estatística de ajuste, neste caso, é o BIC. No entanto, devem ser considerados também outros fatores, como a parcimônia no "consumo de graus de liberdade" e os argumentos analíticos que sustentam cada modelo. Foram testados três modelos: EGP Padrão, EGP Brasil, Interação Total (Full Interaction: fi). Para cada um dos modelos, o BIC é comparado com sua estatística em relação ao modelo de independência. Para evitar redundância, como esta estatística é idêntica para os três modelos, ela será apresentada uma única vez. Além dessa comparação, o modelo multiplicativo testa também o ajuste para os dados sem a consideração dos níveis (null) e o ajuste para o modelo multiplicativo (mult). Isso se justifica para a argumentação pró ou contra o uso do modelo multiplicativo em detrimento do modelo linear. Sempre que o BIC do modelo multiplicativo for inferior ao BIC do modelo linear, é mais indicado o modelo multiplicativo. Em relação aos graus de liberdade, quanto mais graus forem preservados, melhor o modelo se ajusta aos dados. A Tabela 2 traz os dados de BIC e graus de liberdade (df) para os diferentes anos, con- 
siderados os dados para homens entre 20 e 64 anos em todos os níveis de escolaridade. Observe que o modelo multiplicativo consome sempre mais 3 graus de liberdade, em virtude dos 3 níveis adicionais relativos à separação das PNADs consideradas em diferentes etapas.

Tabela 2: Estatísticas de ajuste dos modelos log-multiplicativos para mobilidade de homens entre 20 e 64 anos, com efeito multiplicativo para 1973/82/88/96.

\begin{tabular}{|c|c|c|c|}
\hline Modelos & & BIC & Df \\
\hline Independência & & 64796,9 & 256 \\
\hline \multirow{2}{*}{ EGP Padrão } & Null & $-367,1$ & 242 \\
\cline { 2 - 4 } & Mult & $-484,9$ & 239 \\
\hline \multirow{2}{*}{ EGP Brasil } & Null & $-1065,8$ & 241 \\
\cline { 2 - 4 } & Mult & $-1204,4$ & 238 \\
\hline \multirow{2}{*}{ Interação total } & Null & $-1497,6$ & 192 \\
\cline { 2 - 4 } & Mult & $-1630,4$ & 189 \\
\hline
\end{tabular}

Fonte: PNAD - IBGE.

Modelo: Unidiff, proposto por Xie (1992), gerado pelo Stata.

Apesar de o modelo de interação total registrar o BIC mais baixo, observa-se que o modelo EGP Brasil, proposto por Ribeiro (2002), apresenta ótimo ajuste aos dados e consome poucos graus de liberdade, além de ter largo suporte teórico. Esse conjunto de argumentos mostra-se adequado à sua utilização como referência para as análises seguintes de mobilidade. A partir da análise de ajuste dos modelos e da opção pelo modelo EGP Brasil, importa a produção dos indicadores de associação entre origem e destino para os diferentes anos, níveis educacionais e gêneros. Serão apresentados aqui os indicadores sintéticos de associação, em que o mais importante é medir a variação ao longo do tempo da associação entre Origem e Destino para cada um dos grupos selecionados.

Foram analisados os padrões de mobilidade de homens e mulheres de diferentes níveis de escolaridade. São cinco os níveis de ensino analisados: alfabetizados, primeiro ciclo fundamental, segundo ciclo fundamental, médio ou secundário e superior. Não foram gerados modelos de análise da mobilidade social de pessoas sem instrução ou com menos de um ano de estudo porque as estimativas resultavam em tabelas com muitas células vazias, o que prejudicava imensamente ou inviabilizava a correta convergência dos modelos. O indicador de associação utilizado é o Kappa, estatística clássica de associação dos modelos log-multiplicativos, previstos pela norma padrão de produção de resultados dos modelos de análise escolhidos como referência.

Observou-se que, entre os homens, a associação entre Origem e Destino tende a diminuir entre 1973 e 1996. No entanto, observa-se tendência 
inversa para os homens com ensino superior. O estrato em que havia maior independência da origem social, gradativamente, com sua abertura e maior democratização, parece ser também mais afetado por elementos pré-modernos, como a origem e o capital social, na determinação de seus resultados.

Tabela 3: Estatísticas Kappa de associação entre Origem e Destino no modelo log-multiplicativo de mobilidade de homens entre 20 e 64 anos, para os anos de 1973/82/88/96.

\begin{tabular}{|c|c|c|c|c|c|}
\hline Anos / Níveis & Alfabetizados & Fundamental 1 & Fundamental 2 & Médio & Superior \\
\hline 1973 & 0,48 & 0,62 & 0,59 & 0,53 & 0,41 \\
\hline 1982 & 0,54 & 0,54 & 0,52 & 0,46 & 0,40 \\
\hline 1988 & 0,38 & 0,49 & 0,56 & 0,48 & 0,43 \\
\hline 1996 & 0,47 & 0,49 & 0,51 & 0,49 & 0,45 \\
\hline
\end{tabular}

Observa-se que antes da expansão das vagas registrada sobretudo na década de 1970, ou seja, antes que um maior volume de diplomados pudesse chegar ao mercado, a relação entre origem e destino na determinação dos padrões de mobilidade social dos homens diplomados era bem inferior à observada em outros níveis de escolaridade. Homens com apenas as séries iniciais, que representavam parcelas muito expressivas da força de trabalho até a década de 1980, apresentaram grande dependência da origem social na determinação de sua posição na estratificação de classes: Kappa =0,62 (até a $4^{\text {a }}$ série) e 0,59 (até a 8a série) em 1973; respectivamente 0,54 e 0,52 em 1982. Nesse período, os diplomados experimentavam dependência bem menor, retratada numa associação de 0,41 em 1973 e 0,40 em 1982.

No entanto, em 1996, essa associação subiria para 0,45. Essa elevação de 0,05 pontos foi experimentada de forma exatamente inversa para aqueles que tiveram piores oportunidades escolares. O primeiro nível fundamental registrou associação de 0,49 . No geral, a sociedade brasileira mostrou-se mais aberta e menos conservadora. Contudo, para aqueles que investiram mais em educação e tiveram mais esperanças de obter retornos e trajetórias sociais similares às encontradas quando iniciaram este investimento, o resultado final não se mostrou tão promissor quanto ao da época em que o "sonho moderno" de ascensão social se formou.

Entre as mulheres, observou-se fenômeno similar. Nos casos em que os grupos selecionados apresentavam menos casos e células vazias, optou-se por não estimar um modelo específico, como foi o caso das trabalhadoras apenas alfabetizadas. Para os demais grupos, observou-se que a associação entre origem e destino era, para elas, mais forte e conservadora do que para os homens e, ao longo do tempo, essa relação tendeu a diminuir, revelando a maior abertura do mercado de trabalho e maior fluidez. 
Tabela 4: Estatísticas Kappa OxD no modelo log-multiplicativo de mobilidade de mulheres entre 20 e 64 anos, para os anos de 1973/82/88/96.

\begin{tabular}{|c|c|c|c|c|}
\hline Anos / Níveis & Fundamental 1 & Fundamental 2 & Médio & Superior \\
\hline 1973 & 0,70 & 0,77 & 0,45 & - \\
\hline 1982 & 0,44 & 0,48 & 0,36 & 0,37 \\
\hline 1988 & 0,39 & 0,49 & 0,38 & 0,34 \\
\hline 1996 & 0,40 & 0,38 & 0,35 & 0,44 \\
\hline
\end{tabular}

As oscilações entre as mulheres foram mais significativas do que as observadas entre os homens. As mulheres com ensino fundamental experimentaram, em 1973, uma associação muito forte entre sua posição social e sua origem familiar. A rápida expansão econômica e a abertura do mercado refletiriam, já em 1982, uma mudança significativa nos padrões de associação. Entre 1982 e 1996, houve, como para os homens, um aumento da fluidez muito perceptivo em quase todos os níveis de ensino. A exceção também foi registrada entre as diplomadas. Se para aquelas com o ensino fundamental, a queda da associação oscilou entre quatro e dez pontos entre 1982 e 1996, para as diplomadas a associação subiu de 0,37 para 0,44 nesse mesmo período. Em termos gerais, homens e mulheres vivenciaram uma abertura da sociedade brasileira aos movimentos e à menor dependência da origem social, o que representa um avanço das estruturas modernas. No entanto, tais avanços foram ainda muito singelos no que diz respeito à forte relação que ainda subsistia, em 1996, entre Origens e Destinos sociais.

Tabela 5: Estatísticas Kappa de associação entre Origem e Destino no modelo logmultiplicativo de mobilidade de homens e mulheres entre 20 e 64 anos (1973/82/88/96).

\begin{tabular}{|c|c|c|}
\hline \multirow{2}{*}{ Anos } & \multicolumn{2}{|c|}{ Sexo } \\
\cline { 2 - 3 } & Homens & Mulheres \\
\hline 1973 & 0,76 & 0,82 \\
\hline 1982 & 0,68 & 0,71 \\
\hline 1988 & 0,64 & 0,65 \\
\hline 1996 & 0,64 & 0,60 \\
\hline
\end{tabular}

Enquanto as mulheres experimentavam, antes, um mercado de trabalho extremamente dependente das relações familiares como possibilidade de colocação ocupacional (Kappa = 0,82), ao longo do tempo sua inserção vigorosa no mercado e a elevação de seus atributos produtivos (como a escolaridade) fizeram com que a fluidez fosse maior para elas (Kappa =0,60). No entanto, a associação é ainda muito forte. Sensação similar experimentaram os homens, que não tiveram uma melhoria tão significativa na diminuição 
da associação entre Origem e Destino (de 0,76 para 0,64), mas ainda assim observaram um progresso singelo na abertura da estrutura social.

A comparação entre os indicadores por gênero e por nível de instrução revela, também, que a mobilidade é muito mais fluida entre aqueles de mesmo nível do que entre os sexos, ou seja, entre a população de maneira geral. Assim, entre pares observa-se uma fluidez maior do que a registrada na sociedade como um todo, o que é esperado, mas ainda assim digna de nota em razão da magnitude da diferença. Ao se aceitar a convivência de homens e mulheres em um mesmo mercado de trabalho, com suas características de fluidez e competitividade, pode-se também ensaiar a análise da mesma associação por níveis de ensino tomados em seu conjunto, a partir de grupos mistos de homens e mulheres. As mesmas tendências são observadas nesse caso, permitindo inferir que não é problema grave aceitar a paridade entre os gêneros no tratamento de questões como essa, respeitados os limites para inferências.

Tabela 6: Estatísticas Kappa de associação entre Origem e Destino no modelo logmultiplicativo de mobilidade de homens e mulheres entre 20 e 64 anos (1973/82/88/96), por nível de ensino e para o conjunto das observações (exceto menos de um ano)

\begin{tabular}{|l|c|c|c|c|c|c|}
\hline & \multicolumn{7}{|c|}{ Níveis de Ensino } \\
\hline Anos & Alfabetizados & Fundamental 1 & Fundamental 2 & Médio & Superior & Geral \\
\hline 1973 & 0,51 & 0,63 & 0,60 & 0,51 & 0,38 & 0,78 \\
\hline 1982 & 0,53 & 0,53 & 0,51 & 0,44 & 0,38 & 0,68 \\
\hline 1988 & 0,56 & 0,46 & 0,54 & 0,46 & 0,40 & 0,64 \\
\hline 1996 & 0,44 & 0,45 & 0,48 & 0,45 & 0,45 & 0,63 \\
\hline
\end{tabular}

As tendências descritas anteriormente para homens e mulheres, nos diferentes níveis de ensino, se confirmaram. Houve uma significativa abertura, especialmente até 1988, todavia lenta e ainda muito conservadora. A fluidez dentro de um mesmo nível de instrução ainda é muito maior do que entre um mesmo sexo ou para o conjunto da sociedade. Quase todos os níveis de ensino experimentam maior abertura e fluidez ao longo do período, com a óbvia diminuição da associação entre origem e destino. A exceção é o ensino superior, o que reforça a tese reiterada ao longo deste trabalho acerca dos limites sociais da educação. Em 1996, a associação entre os diferentes níveis de ensino, que antes oscilava entre 0,63 e 0,38 em 1973, estava praticamente estável, em torno de 0,44 e 0,48, revelando uma tendência de convergência e menor peso da educação na determinação dos padrões de fluidez. 


\section{CONSIDERAÇÕES FINAIS}

No Brasil, subsiste ainda uma larga segmentação vertical, em níveis de ensino, derivada da desigualdade estrutural marcante de nossa sociedade. A escolarização permanece como uma das principais vias de mobilidade, de defesa da esperança capitalista na igualdade das oportunidades. Reitera-se a crítica ao propagado potencial da educação de realizar os sonhos modernos, sem considerar os graves limites impostos pela mesma sociedade. O próprio crescimento econômico acabaria por gerar tanto aumento do consumo material, o que é seu objetivo e motor, quanto novas procuras pela massa da população a bens posicionais, e estas tendem a ser frustradas pela escassez social. Isso intensifica a pressão por uma capacidade aquisitiva adicional, manifesta na compulsão distributiva. Tal processo não realiza seus objetivos e gera pressão inflacionária subjacente, o que representa um desperdício social e tende a contribuir para a desigualdade. A igualdade seria, então, "uma quimera", que sequer é de fato pretendida no funcionamento moderno. Algumas desigualdades contribuiriam para ampliar a economia, promover o crescimento material e beneficiar a todos. Logo a teleologia moderna deveria ser guiada por "um grau ótimo de desigualdade".

Próximo ao processo da modernização conservadora, mas sem a referência à manutenção de estágios anteriores de desenvolvimento, aqui a ação social produz um híbrido, com um fator predominante típico do capitalismo moderno e outro fator ligado ao estilo societário que se reproduz sob novos formatos. Isto representa uma dupla adaptação mutuamente favorável. O capitalismo consegue instalar-se com menos resistências e assimilando melhor as formas sociais anteriores. A sociedade se modernizaria sem deixar de operar alguns de seus funcionamentos pré-modernos típicos.

A expansão das matrículas não cumpriu a expectativa de que ela seria capaz de diminuir as desigualdades sociais. A ampliação da escolarização tendeu a diminuir a pobreza e as desigualdades educacionais, mas de forma limitada. A realização de mobilidade social mostrou-se efetiva, embora decrescente, ao longo do tempo. As teses gerais acerca da mobilidade social no Brasil se confirmaram. Os indicadores de mobilidade social são coerentes com os observados em outros países. Verificam-se barreiras à mobilidade entre classes rurais e urbanas, entre classes manuais e não manuais, e entre o conjunto das classes e os estratos superiores. A mobilidade descendente dos estratos superiores é muito baixa, sendo os fatores estruturais os principais responsáveis pela ascensão de diferentes origens à elite. A mobilidade de longo percurso é rara. Nesse caso, o ensino superior cumpre papel relevante. 
No entanto, ao longo do tempo, esse poder de alcance de longa mobilidade em virtude da obtenção do diploma tem se mostrado cada vez mais limitado.

Nossa "modernidade" apresenta-se diversa da estabelecida em outros países. Somos mais dependentes do capital social. Nossos avanços em direção à equalização são contrabalançados por fortes mecanismos de reprodução. Nossa estrutura social e de mobilidade tende a ser cada vez mais "cega" em relação ao gênero, mas não à cor; e ainda enrijece os caminhos para quem é originário de setores manuais - a maior parte da população. Observou-se que aqueles que se encontram em posições menos privilegiadas, ou seja, excluídos do acesso a determinados serviços (como o ensino superior) ou posição social (mobilidade), mas próximos a ele, aproveitam melhor as oportunidades. Isso confirma as hipóteses da Teoria da Desigualdade Maximamente Mantida. De fato, a desigualdade tende a se manter até que o acesso a determinado fator de equidade esteja saturado, ou seja, tenha perdido o seu poder de realização social original. Com poucas oportunidades abertas, a educação pareceu ser o melhor caminho de famílias pobres e pouco escolarizadas. Na definição dessa estratégia social, pareceram pesar mais ao longo do tempo a crença moderna na educação, e seu poder de realização, do que efetivamente as experiências sociais contemporâneas. A educação foi o principal investimento social das famílias e indivíduos, sobretudo no caso das mulheres. A exceção ficou por conta dos grupos menos escolarizados (analfabetos e somente alfabetizados) que tenderam a apostar em outros caminhos de mobilidade, como a migração. Para as famílias mais escolarizadas, o investimento em acréscimo educacional como consumo defensivo demorou a acontecer, mas se consolidou como estratégia de defesa de sua posição social.

A correlação entre mobilidades educacional e social mostrou-se mais forte do que a anteriormente prevista, reiterando a importância da educação como estratégia de mobilidade em sociedades desiguais, como é a brasileira. No entanto, o estudo das tendências ao longo do período revelou claras indicações de elevação do percentual daqueles que obtém mobilidade apenas educacional, sem obtenção da mobilidade social esperada. Espera-se a preservação da correlação entre as mobilidades citadas em razão do acirramento da competitividade na estrutura econômica, que dificulta a manutenção das posições de classe mais elevadas sem a credencial educacional equivalente.

A origem social desempenha um papel muito importante para a determinação dos destinos sociais de todos os estratos sociais, em especial aos superiores, e para todos os níveis de ensino. Observou-se que a relação entre origem e destino na determinação dos padrões de mobilidade social daqueles com nível superior foi bem inferior à observada em outros níveis de 
escolaridade. Essa associação cresceu ao longo do tempo, revelando perda de fluidez social para este estrato. Entre as mulheres, observou-se que a associação entre origem e destino era, para elas, mais forte e conservadora do que para os homens, e ao longo do tempo esse quadro tendeu a se reverter. O Brasil, de forma geral, apresentou tendência similar. A sociedade mostrou-se mais aberta ao longo do período estudado e menos dependente da origem social. Todavia, os avanços foram pouco significativos em relação ao tamanho das desigualdades e dos mecanismos de sua reprodução. De outro lado, o nível superior, que antes se caracterizava como o mais aberto e com características modernas de meritocracia e fluidez, experimentou um enrijecimento de seu padrão de realização social, ampliando ao longo do período sua dependência da origem social na determinação do destino e praticamente se igualando aos padrões de associação entre origem e destino registrados em outros níveis educacionais, ou seja, registrando diminuição de seu poder de mobilidade social.

THE SOCIAL BOUNDARIES OF EDUCATIONAL POLICIES: EQUALITY, MOBILITY AND SOCIAL STRATIFICATION

ABSTRACT: Present day expectations to bring about equality of opportunity through the democratization of the public school system are hampered by social boundaries. Hirsch's thesis (1979) can be applied to the case, especially in periods of democracy. Broader access to educational credentials tends to shift the inequality to horizontal levels (Collins, 1979). As enrollments expand numerically, the social effects of education tend to lose their quality and social power. Whereas before, education was a modern mechanism for upward mobility depending little on social origin, it is now losing its characteristic of equality without having removed mechanisms which reproduce inequality. A critical analysis of this model of enrollment expansion points to the need to review its goals and mechanisms for building democracy.

KEYWORDs: Sociology of Education. Higher Education. Social Mobility. Social Classes.

\section{NOTAS}

1. O estudo refere-se a uma pesquisa comparada sobre a relação entre educação e mercado de trabalho, em 14 capítulos, englobando estes 13 países (dois deles dedicados ao caso japonês): Alemanha, Irlanda, Japão, Taiwan, Israel, Suíça, Holanda, Grã-Bretanha, Austrália, França, Itália, Suécia e Estados Unidos.

2. As comparações referem-se aos fenômenos observados no final do século XX em relação a estudos anteriores, em geral esparsos, publicados em grande parte nas décadas de 1960 e 1970. 


\section{REFERÊNCIAS}

ANDORKA, Rudolph. Social Mobility and Education in Hungary: An analysis applying Boudon's model. Information sur les sciences sociales, v. 15, n. 1, 1976, p. 47-70, 1976.

BASTOS, Ana Paula Barbosa Leite. Herdeiros ou sobreviventes: mobilidade social no ensino superior no Rio de Janeiro. Dissertação de Mestrado no Instituto de Filosofia e Ciências Sociais da Universidade Federal do Rio de Janeiro. 2004.

BOUDON, Raymond. Efeitos perversos e ordem social. Rio de Janeiro: Zahar, 1979.

BOURDIEU, Pierre. La Distincíon: Critérios y bases sociales del gusto. (2. ed.). Madri: Taurus, 2000.

CHAUVEL, Louis. Cohort Changes in Education, Social Stratification and Mobility, the Case of France (1964-1995). International Sociological Association (ISA), Research Committee 28 on Social Stratification and Mobility (http://www.soc.duke.edu/ rc28/). Conference Paper, Montreal, 1998.

COLEMAN, James S. et al. Report on Equality of Educational Opportunity. U.S. Government Printing Office for Department of Health, Education and Welfare, 1966.

COLLINS, Randall. The credential society : an historical sociology of education and stratification. Nova York: Academic Press, 1979.

CUNHA, Maria Neli Ribeiro. Mobilidade Sociale Educação: a dualidade no ensino superior. Viçosa, MG, Dissertação de Mestrado em Economia Doméstica, 1998.

ERIKSON, Robert e GOLDTHORPE, John H. The constant flux: a study of class mobility in industrial societies. Oxford: Oxford University Press, 1993.

FIGUEIREDO, Fábio Ferreira. Educação Superior e Mobilidade Social: Limites, Possibilidades e Conquistas. Tese de Doutorado. Pontifícia Universidade Católica de São Paulo. 2006.

GOLDTHORPE, John H. On sociology: numbers, narratives, and the integration of research and theory. Nova York: Oxford Univ. Press, 2000.

GROSS, Martin. Educational Systems, Intragenerational Mobility and Perceived Social Inequality. International Sociological Association (ISA), Research Committee 28 on Social Stratification and Mobility (http://www.soc.duke.edu/ rc28/). Conference Paper, Montreal, 1998.

HIRSCH, Fred. Limites Sociais do Crescimento. Rio de Janeiro: Jorge Zahar, 1979.

INSTITUTO BRASILEIRO DE GEOGRAFIA E ESTATÍTICA - IBGE. Pesquisa Nacional por Amostra de Domicílios - PNAD. Rio de Janeiro, CDs de microdados, de 1976 a 2008.

JACKSON, Michelle; GOLDTHORPE, John H. e MILLS, Colin. Education, Employers and Class Mobility. International Sociological Association (ISA), Research Committee 28 on Social Stratification and Mobility (http://www.soc.duke.edu/ rc28/). Conference Paper, Oxford, 2002. 
MURPHY, Raymond. Social closure: the theory of monopolization and exclusion. Oxford: Claredon Press, 1988.

RIBEIRO, Carlos Antonio Costa. The Brazilian occupational structure. Tese de doutorado, Columbia University, 2002.

SCHWARTZMAN, Simon. A Revolução Silenciosa do Ensino Superior. In: DURHAM, Eunice R. e SAMPAIO, Helena. O Ensino Superior em Transformação. São Paulo: Núcleo de Pesquisas sobre Ensino Superior da USP, 2001. p. 13-30.

SCHWARTZMAN, Simon. Universities and the Transformation of Society in Brazil. Paper prepared for the research project on "The Role of Universities in the Transformation of Societies", The Centre for Higher Education Research and Information (CHERI) of the UK Open University and the Association of Commonwealth Universities (ACU). October 2003.

SHAVIT, Y. e MULLER, W. From school to work: a comparative study of educational qualifications and occupational destinations. Oxford, Clarendon Press/Oxford Univ. Press, 1998.

TITMA, Mikk; TUMA, Nancy Brandon e ROOSMA, Kadi. Education as a Factor in Intergenerational Mobility in Soviet Society. International Sociological Association (ISA), Research Committee 28 on Social Stratification and Mobility (http://www.soc.duke. edu/ rc28/). Conference Paper, Oxford, 2002.

VALLE SILVA, Nelson do. As duas faces da mobilidade social. Dados, n. 21, 1979. p. 49-58.

Race, schooling and social mobility in Brazil. Ciência e Cultura, v. 51, n. 5/6, set. 1999.

; HASENBALG, Carlos. Trends in educational inequality in Brazil. Dados, v. 43, n. 3, 2000.

; HASENBALG, Carlos (Orgs.). Origens e destinos: desigualdades sociais ao longo da vida. Rio de Janeiro: IUPERJ/UCAM/Topbooks, 2003.

; PASTORE, José. Mobilidade Social no Brasil. São Paulo: Makron Books, 1998.

XIE, Yu. "The Log-Multiplicative Layer Effect Model for Comparing Mobility Tables". American Sociological Review, n. 57, p. 380-395, 1992.

Fernando Tavares Júnior é Professor Doutor do Departamento de Ciências Sociais - Instituto de Ciências Humanas da Universidade Federal de Juiz de Fora. É coordenador do Grupo 2 - Unidade de Pesquisa do CAEd (Centro de Políticas Públicas e Avaliação da Educação) Faculdade de Educação/UFJF.

E-mail: ftavares@caed.ufjf.br 



\title{
GESTÃO PEDAGÓGICA DE CURSOS DE LICENCIATURA EM UMA UNIVERSIDADE PÚBLICA: CONTRIBUIÇÕES PARA UMA REFLEXÃO*
}

\author{
Glaucia Maria da Silva, \\ da Universidade de São Paulo, Ribeirão Preto \\ Noeli Prestes Padilha Rivas, \\ da Universidade de São Paulo, Ribeirão Preto
}

\begin{abstract}
REsUMo: Este trabalho apresenta reflexões acerca de experiências na coordenação de cursos de graduação de formação de professores no contexto de uma universidade pública brasileira, enfocando elementos facilitadores e elementos limitantes de construção de um processo coletivo, tendo os projetos pedagógicos dos cursos como instrumentos de gestão. Entre os elementos facilitadores são apontados e analisados alguns dispositivos legais e cursos de formação docente, promovidos pela universidade, que enfocam o tema da gestão. Quanto aos limites, são mencionados, dentre outros, dificuldades de construção do trabalho coletivo, sobrecarga de trabalho dos docentes, condições de ofertas dos cursos de graduação, valorização e prioridade da pesquisa em detrimento do ensino.

Palavras-chave: Gestão Pedagógica na Educação Superior. Coordenação de Cursos de Graduação. Currículo. Formação de Professores.
\end{abstract}

\section{INTRODUÇÃO}

Este texto analisa o processo de gestão de cursos de graduação no contexto de uma universidade pública, a partir da atuação da Coordenação de Curso (COC), que tem como principais atividades a coordenação, implementação e avaliação do projeto pedagógico do curso. Trata-se de estudo reflexivo, no qual as autoras analisam suas experiências em

* Artigo recebido em 11/05/2011 e aprovado em 12/07/2011. 
coordenação de cursos de graduação, modalidade de licenciatura na área de Educação (Pedagogia) e de Química, focalizando os elementos facilitadores e os limites de construção de um processo de gestão democrática e coletiva. As atuais políticas nacionais de graduação indicam a necessidade de haver mudanças no ensino, como a participação dos docentes na elaboração e implementação do projeto pedagógico de seus cursos, o incentivo às práticas de estudos independentes e às atividades que instiguem a investigação e o desenvolvimento da capacidade crítica do estudante, promovendo autonomia profissional e intelectual, a formação integral, o atendimento à demanda social, o fortalecimento da articulação teoria-prática e da interdisciplinaridade, dentre outras. Essas indicações aliadas à expansão nacional e internacional do campo de saber da pedagogia universitária e ao compromisso e interesse de muitos docentes da universidade, em relação ao ensino de graduação, vêm constituindo-se em elementos facilitadores de mudanças.

O texto apresenta três momentos que se interligam por meio de um eixo gerador, que é a gestão de cursos de graduação na Universidade. No primeiro momento, aborda-se o contexto das políticas de gestão na universidade situando seu campo epistemológico, os ordenamentos legais e políticos da educação superior no Brasil e América Latina. Depois, analisa-se a gestão dos cursos de licenciatura em uma universidade pública pontuando os elementos facilitadores e limitantes do processo organizativo e pedagógico. Finaliza-se o artigo, elencando alguns eixos norteadores que balizam a tessitura de ações na área da gestão de cursos e que possibilitam a reflexão acerca da gestão pedagógica e da qualidade no Ensino Superior.

\section{APONTAMENTOS SOBRE A GESTÃO EDUCACIONAL NA EDUCAÇÃO SUPERIOR}

As universidades brasileiras, de uma forma geral, a partir do final da década de 1980, vêm buscando a qualificação da gestão pedagógica no ensino de graduação por meio de várias ações que se expressam, dentre outras, na elaboração e no acompanhamento dos projetos pedagógicos dos cursos de graduação. Nesse sentido, a expressão "gestão educacional" começa a ganhar força na literatura com a orientação de ações educacionais, significando o processo de gerir a dinâmica do sistema de ensino como totalidade e coordenação de instituições de ensino, em sintonia com as políticas educacionais públicas, tendo em vista a implementação de políticas educacionais e projetos pedagógicos fundamentados em princípios democráticos e participativos (LÜCK, 2010).

No campo das ciências sociais e humanas, essa situação gera perplexidade e tensão. Os ordenamentos internacionais (transnacionalização, gestão 
da educação superior) balizados fortemente pelo controle estatal afetam a relação estado/universidade, seja pela presença do estado avaliador (Neave, 1999), seja pela instauração de estratégias de mercado, de políticas públicas e de gestão (Dale, 1999; Afonso, 2000; Morosini e Morosini, 2006) na lógica da crise do Estado proposta por Santos (2004). Essa perspectiva globalizada se estende à educação e ao campo do conhecimento, cujo discurso assenta-se na concepção de sociedade da informação e comunicação, na fragmentação do conhecimento como instrumentalização e sua concepção como commodities.

Reconhece-se, atualmente, que há uma diversidade de modelos de universidades e tipos de conhecimento, em detrimento do modelo tradicional de universidade e suas antigas funções que congregava para si o monopólio de construção do conhecimento. Delanty (2001) aponta que a universidade pós-moderna contesta o conhecimento global e reconhece a emergência de conhecimentos locais. Existem muitos tipos de conhecimento e um crescente ceticismo sobre a afirmação de universalismo construído sobre valores da racionalidade cognitiva (MOROSINI e MOROSINI, 2006). Nessa transição entre o moderno e o pós-moderno, paralelo à desreferencialização do conhecimento trazido pela pós-modernidade, os países desenvolvidos propõem como modelo a Universidade Sustentável que busca fortificar elementos institucionais mantenedores da transformação, paralelo a novas mudanças, tais como "diversificação da base financeira; fortificação do centro diretivo; expansão do desenvolvimento periférico; estímulo à comunidade acadêmica; e integração da cultura empreendedora" (Morosini e Morosini 2006, p. 3).

O neoliberalismo, na forma como aparece no campo educacional, não só substitui a reflexão teórica pela afirmação "de um catálogo de princípios e de verdades irreversíveis de caráter doutrinário" (Frigoto e Ciavatta, 2001 , p. 13), mas enseja novos modelos de universidade na perspectiva da produtividade, passando a ser arquitetada como parte do problema econômico de cada país (Sguissardi, 2004). Enfocando a Universidade brasileira em seus desafios políticos e epistemológicos, Cunha (2009) comenta que a complexidade do contexto no fim do século XX e começo do século XXI, marcada por ideologias neoliberais e visões conservadoras, levou à reorientação dos sistemas educacionais, a fim de valorizar o mercado como eixo definidor de políticas nessa área. Além disso, buscou-se uma pedagogia que, influenciada por esse processo, também assumisse a parceria com processos produtivos como primeiro compromisso educativo. Chauí (2003) dialoga com este contexto quando destaca que a universidade está deixando de ser uma instituição, que se percebe inserida na divisão social e política e 
na busca de uma universalidade que lhe permita responder às contradições presentes na sociedade, para se tornar uma organização burocrática. Para a autora, a universidade direciona o currículo e os docentes à preparação de alunos para o mercado, perdendo sua principal característica de reflexão e de formação intelectual.

Os desafios para a gestão da educação pública, no atual contexto, são inúmeros e complexos. No Brasil, a gestão democrática da educação figura como norma jurídica na Constituição Federal de 1988 (CF, 5/10/1988), na Lei de Diretrizes e Bases da Educação Nacional (LDB, Lei n. 9.394/96, de 20/12/1996) e no Plano Nacional de Educação (PNE - Lei n. 10.127, 09/1/2001), mas sua regulamentação tem sugerido uma diversidade de interpretações que variam conforme o lugar e os agentes envolvidos.

Quando se constatam esforços efetivos para a melhoria do ensino, estes são localizados e pontuais, já que a demanda por força de trabalho com qualificações mais complexas não advém de todos os setores da economia brasileira, mas apenas de setores que competem com os segmentos mais inovadores e produtivos da economia mundial. Verifica-se a adequação do sistema educacional à heterogeneidade das demandas do sistema econômico, que aponta para a qualificação da força de trabalho não apenas no âmbito nacional, mas mundial. Como decorrência, e em razão da crescente mobilidade do capital, a educação deixou de ser uma questão nacional, tornando-se campo de disputa dos organismos transnacionais.

Bruno (2002), ao refletir sobre questões semelhantes a respeito da gestão democrática e contextos complexos, assinala que

melhorar a qualidade da educação vai muito além da promoção de reformas curriculares, implica, antes de tudo, criar novas formas de organização do trabalho na instituição escolar, que não apenas se contraponham às formas contemporâneas de organização e exercício do poder, mas que constituam alternativas práticas possíveis de se desenvolverem e de se generalizarem, pautadas não pelas hierarquias de comando, mas por laços de solidariedade, que consubstanciam formas coletivas de trabalho, instituindo uma lógica inovadora no âmbito das relações sociais. (p. 44)

Essas novas formas de organização do trabalho apontadas pela autora nos remete aos dispositivos político-sociais e legais que trazem à tona a necessidade da formação inicial e continuada não apenas de profissionais aptos para uma determinada atividade, mas de sujeitos historicamente situados, comprometidos socialmente. Nesse aspecto devem ser repensados os conhecimentos produzidos e suas articulações entre si e com a realidade, os modelos curriculares, as concepções e estratégias metodológicas 
e de avaliação utilizadas em salas de aula, enfim, deve ser retomada a intencionalidade das práticas educativas no contexto universitário. Esse repensar mostra-se desafiante e traz demandas específicas para a coordenação dos cursos de graduação, sendo fundamental a construção de processos de gestão pedagógica que ultrapassem a lógica burocrática e operacional, em direção a processos democráticos e coletivos.

A gestão de órgãos superiores dos sistemas de ensino e instituições educacionais é demarcada pelos processos sociais que contemplam contínuas interações de seus elementos plurais e diversificados (Lück, 2010), os quais estão relacionados aos objetivos institucionais. Assim, é importante ressaltar que as mudanças ocorrem mediante processo de transformação, caracterização pela produção de ideias, processos e estratégias promovidos pela mobilização do talento e energia internos e acordos consensuais.

Na universidade pública, em análise, tem havido a proposição de políticas e ações de valorização do ensino de graduação que buscam colocar na pauta cotidiana a atividade de ensino como função precípua da universidade que, aliada às atividades de pesquisa e extensão, possa contribuir para o avanço do conhecimento científico e cultural, respondendo às necessidades sociais. Todavia, essa possibilidade confronta-se com outras intencionalidades presentes no conjunto da Universidade, prioritariamente fundamentadas na lógica da produtividade. Enfocar a gestão do ensino e, de modo mais específico e restrito, a gestão pedagógica cotidiana dos cursos de graduação, foco deste texto, torna-se tarefa desafiante a ser aprendida, na medida em que se trata de proposta que busca extrapolar o cumprimento normativo e burocrático que faz funcionar o ensino, incorporando o processo reflexivo sobre o projeto de formação que se pretende implementar como cerne. Algumas questões (que modelo de sociedade se pretende construir e fortalecer; qual aluno se pretende formar; quais os fundamentos políticos, culturais, curriculares e pedagógicos que permeiam as práticas educativas relacionadas ao processo de ensino e aprendizagem) balizam os processos de tomada de decisão sobre o ensino nos cursos de graduação, para que não se perca o sentido do que se produz e o compromisso social da Universidade pública.

A partir de nossas experiências em comissões de coordenação de cursos de graduação, nas áreas de Educação e Química, apontamos alguns elementos facilitadores, fundamentados na literatura atual cujo enfoque centra-se no papel da gestão em uma universidade pública, tendo como pressuposto a perspectiva crítica da educação. Estes elementos, apesar do contexto tensionado no âmbito da sociedade e do papel da universidade, 
podem ser apontados como promotores de mudanças na gestão dos cursos de graduação e se referem aos dispositivos político-legais que trazem novos indicativos para a organização do ensino superior no Brasil, bem como impulsionam a revisão das práticas pedagógicas e implicações para a gestão.

O primeiro insere-se no âmbito das políticas macro e diz respeito à Conferência Regional de Educação Superior para a América Latina e Caribe (CRES/2008) a qual teve como objetivo analisar e propor políticas estratégicas para a educação superior da região, reafirmando o seu princípio de direito humano e bem público e social. No Brasil, o documento preparatório à Conferência Mundial de 2009 ressalta como prioridade a construção da "universidade socialmente relevante". O segundo refere-se à construção do Plano Nacional de Educação 2011-2020, incorporando ações de inclusão, de atendimento à diversidade, de promoção da igualdade e de gestão democrática na agenda da educação superior brasileira para o próximo decênio, a partir dos eixos: Currículo da educação superior; Expansão e democratização da educação superior; Financiamento da educação superior; Gestão e avaliação da educação superior; Formação e valorização dos profissionais da educação superior (CURY, 2009, p. 15).

O terceiro relaciona-se à Lei de Diretrizes e Bases da Educação Nacional (LDB - Lei n. 9.394/96) e Diretrizes Curriculares Nacionais (DCNs) para os cursos de graduação, fundamentando-se em parâmetros como construção coletiva do projeto pedagógico, flexibilidade, formação integral, incorporação de atividades complementares, interdisciplinaridade e articulação teoriaprática (Plano Nacional de Graduação, 1999).

Concordamos com Ferreira (2006), em relação ao compromisso da gestão que também se faz em sala de aula, no exercício da docência e da necessária diretividade para a consecução do planejado e organizado em sala de aula e nos espaços institucionais. Nesse sentido, a gestão da educação envolve a garantia de qualidade do processo educativo, considerando-se os determinantes políticos, sociais, culturais e educacionais.

\section{A GESTÃO DOS CURSOS DE LICENCIATURA: ELEMENTOS FACILITADORES}

A partir de 2008, houve uma mobilização da Pró-Reitoria de Graduação da Universidade de São Paulo que, por meio da formação de um grupo de trabalho constituído por docentes de diversos cursos e campos de saber, desenvolveu uma proposta de discussão e revisão da legislação interna acerca das atribuições e da organização das "Comissões de Coordenação de Curso" (CoC). Essa proposta, consubstanciada por meio da Resolução CoG n 5.500, de 13 de janeiro de 2009 (USP, 2009), possibilita às unidades de ensino com- 
porem comissões para acompanhar pedagogicamente o desenvolvimento dos cursos de graduação, tendo o projeto pedagógico do curso como instrumento do processo de gestão. Destaca-se, na elaboração deste documento, a intenção de promover, nos distintos cursos, a gestão pedagógica alicerçada em valores democráticos, sendo os docentes participantes dessas comissões responsáveis por viabilizarem espaços de discussão compartilhada sobre a construção cotidiana do projeto pedagógico dos cursos. O artigo $4^{\circ}$ dessa Resolução especifica que "a composição da CoC e os critérios da eleição de seus membros serão aprovados pelo CoG, a partir de proposta da Comissão de Graduação (CG) ratificada pela Congregação" da unidade responsável pelo curso de graduação. As atribuições da gestão da CoC estão definidas no artigo $2^{\circ}$ e, em sua maioria, tratam da implementação, da coordenação, do acompanhamento e da avaliação do projeto político-pedagógico do curso considerando-se as questões relacionadas ao currículo e ao aluno, bem como aos temas relacionados à inovação pedagógica. Para Veiga (2001), a execução de um projeto pedagógico necessita considerar alguns aspectos: que ele seja construído a partir da própria realidade, considerando os problemas existentes e as situações nas quais aparecem; que seja exequível, sendo previstas as condições necessárias ao seu desenvolvimento e à avaliação; que ele se construa e se implemente por ação articulada entre todos os envolvidos com a realidade da escola, sendo construído continuamente, pois ao mesmo tempo é produto e processo. Outro ponto que emerge como fundamental é perceber o projeto pedagógico como instrumento de gestão, o que implica tocar na necessidade de construção cotidiana do trabalho coletivo, sendo esse mais um importante desafio para as coordenações de curso. Esse desafio relaciona-se ao enfrentamento de se lidar com o predomínio do trabalho mais individualizado do docente universitário, bem como com as estruturas departamentais que acabam fragmentando o curso em disciplinas e, consequentemente, atingindo os docentes, pois estes perdem a visão de unidade que se tece pela interligação, pelo diálogo e pela negociação dos saberes, das experiências, dos sujeitos em suas intencionalidades na construção do curso.

Considerando que o foco deste trabalho centra-se na gestão de cursos de formação de professores, ressalta-se como um dos elementos facilitadores a implantação do Programa de Formação de Professores (PFPUSP) da USP, 2004, e a decorrente criação da Comissão Interunidades de Licenciatura (CIL) que trazem delineamentos para os projetos formativos dos cursos, os quais passam a se constituir em torno de valores, concepções e práticas comuns que não negam as diversidades, mas apontam para a construção de uma unidade possível. O PFPUSP tem por finalidade a formação 
inicial de professores para a educação básica, com capacidade científica e profissional, politicamente motivados a lidar com a diversidade da população atendida hoje pela escola básica brasileira. A concretização desse ideal requer a formação de um professor não apenas dotado de competência em sua área de saber, mas também capaz de compreender essa diversidade, de modo a corresponder às expectativas daqueles que frequentam a escola. Tal compreensão pressupõe o entendimento de que as respostas mais adequadas para cada comunidade escolar emergirão de um trabalho compartilhado e que deve ser objeto de discussão nos cursos de licenciatura/formação de professores. Na relação diversidade-unidade dos cursos, os processos de gestão podem ser fortalecidos.

Cabe ainda considerar que alguns cursos de formação dos próprios professores da universidade, promovidos pela Pró-Reitoria de Graduação e grupos de apoio pedagógico, vêm favorecendo a discussão e construção de conhecimentos sobre gestão de cursos pelos docentes envolvidos. Quanto aos limites para a construção da gestão pedagógica dos cursos, na direção apontada, mencionamos as dificuldades em articular as distintas instâncias de poder que estão implicadas nas decisões acerca do ensino de graduação nas unidades de ensino, essencialmente os departamentos. Nesse sentido, Sabadia (1998) apresenta uma experiência de coordenação de curso em uma universidade federal brasileira e aponta dificuldades institucionais, tais como: limitado apoio ao trabalho das coordenações por parte de departamentos no que se refere à infraestrutura, pessoal e participação no processo decisório; pouco reconhecimento da importância das coordenações pelas instâncias acadêmicas; ausência de representação das coordenações junto aos órgãos colegiados superiores; conflitos políticos e administrativos entre as coordenações e os departamentos no que diz respeito às questões pedagógicas, como mudança de currículo, designação de professores, aprovação de programas e oferecimento de disciplinas; falta de infraestrutura adequada para o funcionamento das coordenações. Essas dificuldades não são estranhas ao nosso contexto cotidiano e, provavelmente, enfrentálas, redimensioná-las e superá-las, na construção de outras relações, será imprescindível para o trabalho da Comissão Coordenadora de Curso.

A gestão possibilita superar o limite da fragmentação e da descontextualização, construindo pela perspectiva abrangente e interativa. Nesse sentido, a gestão constitui-se uma ação participativa (Lück, 2010). É a intencionalidade do que se quer fazer que orienta a direção da ação e os modos de organizar a execução. É ela que norteia o que se apresenta como desejado e necessário. Isso implica especificar determinada intenção de ações e fins 
almejados que se fundamentam naquilo que é valorizado por uma coletividade, em dado momento histórico, em uma determinada sociedade. Trata-se de uma proposta de trabalho que não se alicerça em interesses individualistas, mas no interesse comum de um grupo de profissionais que, ao definiremse no coletivo, orientam tanto o destino de sua instituição como o destino dos homens e das mulheres que formam, pois "um processo de gestão que construa coletivamente um projeto pedagógico de trabalho tem já, na raiz, a potência da transformação" (Ferreira, 2006, p. 113).

Nesse aspecto, torna-se importante refletir sobre as dificuldades de construção do trabalho coletivo. Zabalza (2004) refere-se aos "jogos de poder" presentes entre os distintos grupos culturais da universidade. Um dos limites relacionados à gestão a ser considerado refere-se ao desconhecimento da comunidade universitária em relação ao sentido pedagógico da gestão de curso, tendo em vista que predominam, historicamente, práticas burocratizadas. Além deste, destacam-se o horário de oferecimento do curso no período noturno; a baixa valorização da formação de professores; o perfil dos alunos que apresentam peculiaridades sociais e percursos escolares específicos (aluno trabalhador, limitado capital cultural, entre outros).

Tendo em vista a perspectiva de gestão democrática, envolvendo decisões coletivas, apresentamos nossa proposta com eixos de ações que, em um primeiro momento, subsidiam as ações das comissões de coordenação dos cursos de licenciatura, com o intuito de contemplar as atividades de gestão do ensino e configurá-las num outro patamar. É fundamental que um plano de gestão seja produto compartilhado por docentes e alunos que compõem a CoC-Licenciatura, para que realmente sejam construídas identidades coerentes com uma proposta de gestão democrática, viabilizando a efetivação das ações cotidianas, para além do cumprimento meramente dos aspectos burocráticos. Não basta que o Plano de Gestão das CoCs-Licenciatura seja conhecido apenas por seus integrantes, é necessário socializá-lo com a comunidade universitária diretamente implicada. A intenção é fortalecer o diálogo e a tomada de decisões coletivas, considerando o projeto pedagógico como instrumento de gestão que baliza a construção cotidiana do ensino acompanhamento e avaliação processual. Todos os eixos/ações propostos estão inseridos em permanente processo avaliativo do ensino, envolvendo o currículo, o processo ensino-aprendizagem e a própria gestão do curso de licenciatura.

Essa proposta considera o processo de acompanhamento e avaliação de cursos de graduação que vem sendo construídos, a partir da proposta institucional da Câmara de Avaliação da Pró-Reitoria de Graduação desde 2008 
e o Plano Trienal (2009 - 2011) de Metas e Ações para o Curso de Licenciatura em Química e Pedagogia que apontam problemáticas e ações percebidas e propostas.

A seguir, são delineados eixos norteadores/ações, que se desdobram em "desenvolvimento do currículo", "desenvolvimento do processo ensinoaprendizagem em sala de aula e cenários práticos", "gestão do ensino e formação pedagógica do corpo docente". Para cada eixo, organiza-se uma série de ações e formas de operacionalização.

\section{EIXOS NORTEADORES E TESSITURA DE AÇÕES}

Cabe explicar que "acompanhamento" supõe diagnóstico de problemas, por meio de estratégias de discussão/reflexão grupal, análise dos problemas em seus determinantes, articulações e implicações, negociação de propostas de mudanças que também serão reavaliadas, ou seja, processo permanente de planejamento participativo, tendo como foco o projeto pedagógico do curso que, durante todo o tempo, deve ser discutido, avaliado e recomposto. É importante ressaltar que, ao longo do tempo, apesar de as articulações com grupos específicos de professores serem necessárias, esse espaço também deve ser compartilhado pelo colegiado de curso, dando potencialidade para a construção da ideia de curso como uma tessitura, organicamente articulado, considerando-se a indissociabilidade de ensino, pesquisa e extensão.

1. O Projeto Político-Pedagógico (PPP) como instrumento de gestão: Implantação/Implementação do PPP e Desenvolvimento do Currículo Acompanhamento do processo de implementação curricular dos cursos de licenciatura em Pedagogia e Química, implantados respectivamente em 2002 e 2003. Ambos os cursos seguiram as orientações dos dispositivos legais específicos, bem como o Programa de Formação de Professores da USP (em fase de elaboração na época) de tal modo que, apesar de suas delimitações, apontam para a construção de currículo integrado, articulando a formação ao mundo do trabalho, à formação básica e específica, aos componentes curriculares básicos e pedagógicos. A docência, a vida na escola e as instituições a ela ligadas, na peculiaridade de seus saberes, valores, metas e práticas cotidianas, foram objetos privilegiados visando à preparação para o exercício profissional e da cidadania na sociedade contemporânea. A formação de professores parte da noção de que a docência não se realiza num quadro abstrato de relações individualizadas de ensino e aprendizagem, mas num complexo contexto social e institucional. As instituições escolares, 
embora em constante e forte diálogo com outras instituições, têm história, valores, saberes e práticas que Ihes são específicos e, nesse sentido, têm um papel social peculiar. Não raramente, essa especificidade tem sido obscurecida pela incorporação e transposição acrítica de teorias, conceitos e perspectivas forjados a partir de interesses alheios à educação como um direito público. Importa, pois, que os princípios que norteiam a formação de professores se voltem para a análise das peculiaridades históricas dessas instituições, de seus agentes sociais e das tarefas.

1.1 Ações: As ações previstas nos cursos de licenciatura em Pedagogia e Química abrangem o acompanhamento do desenvolvimento do currículo em cada ano e por grandes áreas - básica /específica em química, fundamentos da educação e metodologias específicas em pedagogia, revisão e atualização do perfil profissiográfico, conteúdos/competência, articulações já feitas e outras a construir, carga horária, além de outras atividades propostas -, flexibilização curricular, relações com realidade/articulação teoria-prática, estágio curricular supervisionado, tendo em vista que este componente constitui-se eixo formativo e de pesquisa para todos os cursos de licenciatura mencionados.

1.2 Operacionalização: Ao envio anual da estrutura curricular para o Conselho de Graduação, cada curso de licenciatura pode pactuar um cronograma institucional para a realização de oficinas, organizadas por grupos de docentes e alunos (e, quando for possível, pelos demais sujeitos envolvidos - gestores e profissionais de serviços de saúde, escolas de educação profissional, de educação básica e instituições que auxiliem os alunos licenciados e criem espaços formativos e profissionais). Outra ação pode ser planejada, tal como a realização de encontros entre os professores de cada ano para a construção da "matriz" de horários anual e/ou semestral - esse momento deve ultrapassar o cumprimento apenas burocrático dos horários para fomentar espaço reflexivo sobre o currículo como, por exemplo, problematizar, a partir dos horários, a oferta de aulas e atividades aos sábados, até porque uma grande maioria de nossos alunos é formada por trabalhadores; uma situação muito peculiar no Brasil.

\section{Desenvolvimento do processo ensino-aprendizagem em sala de aula e cenários práticos}

2.1 Ações: Acompanhamento do desenvolvimento das atividades de ensino - planejamento das disciplinas - objetivos, conteúdos/competência, metodologia, avaliação, recursos e infraestrutura disponíveis. Nesse eixo, as dificuldades encontradas referem-se à utilização de metodologia crítica problematizadora fundamentada em perspectiva crítica da educação; ao 
enfoque no referencial da competência dialógica; à construção do processo de avaliação formativo e aos embates originados pela concepção de ciência e pela tradição da universidade.

2.2 Operacionalização: Realização de oficinas de trabalho, cursos formativos e/ou reuniões de estudo, realizadas durante o ano, com os docentes e representantes de estudantes com o objetivo de acompanhar a implantação do Projeto Político-Pedagógico do Curso - PPPC, bem como discutir e analisar os programas de "aprendizagem" propostos nas disciplinas. Nesse momento, poderão ser revistas as possibilidades articuladoras de conteúdos e mesmo de processos avaliativos, também oportunizar a troca de experiências sobre métodos e estratégias de ensino empregados em sala de aula. Além dessas atividades, acrescenta-se a parceria com o Grupo de Avaliação do Ensino de Graduação e Comissão de Graduação (CG) e outros grupos institucionais que visam estimular a discussão sobre os instrumentos de avaliação que os docentes vêm adotando nas disciplinas e a possibilidade de elaboração de um instrumento institucional, o que possibilita a busca de informações que subsidiem a avaliação do ensino.

3. Gestão do Ensino: Cabe à Comissão Coordenadora de Cursos (CoC) realizar permanente processo reflexivo sobre o seu próprio trabalho (autoavaliação), reconfigurando ações e modos de atuar na comunidade e internamente no grupo. A intenção é formar um grupo que se constitui no percurso desse processo para coordenar a gestão do curso. É importante que a $\mathrm{CoC}$ mantenha diálogo com a CG a quem assessora e com os departamentos representados pelas chefias, uma vez que nas Unidades da Universidade ainda não existe a cultura do trabalho de gestão pedagógica de curso que será efetivada pela CoC-Licenciatura. Esta nova sistemática contribui para o enfrentamento de conflitos, para a tomada de decisão acerca de ações a serem cumpridas. Isso demandará árduo trabalho político de negociação, com foco na valorização do ensino de graduação. Cabe também, nesse eixo, investir na formação dos docentes da $\mathrm{CoC}$ no âmbito da gestão do ensino, oferecendo condições para que o grupo aprimore seu desempenho. Essa formação construir-se-á continuamente, na medida em que o grupo conseguir realmente estabelecer um trabalho articulado, fundamentado no processo reflexivo sobre o ensino do curso de licenciatura e sobre seu próprio fazer fundamentado nas relações democráticas e participativas.

3.1 Ação: Organização de um trabalho interno do grupo, a "divisão" de responsabilidade em torno do plano de gestão e as interfaces do grupo com a CG, os Departamentos e toda a comunidade das unidades envolvidas. 
3.2 Operacionalização: Os participantes da CoC devem estabelecer uma agenda e um planejamento de ações elencadas de acordo com as prioridades. Além disso, este grupo, mediado pelo coordenador de curso, pode estabelecer um processo de comunicação com a comunidade, de modo que garanta a troca aberta de informações. No início do trabalho das CoCs, deverá ser feita uma reunião com representantes da CG com a finalidade de compartilhar este Plano de gestão, uma vez que a CoC é uma Comissão Assessora da CG. Nesta reunião, pode ser sugerida a elaboração de um fluxo de trabalho para os trâmites cotidianos de gestão do ensino, evitando duplicidade de tarefas e informações. Uma ação fundamental, neste contexto, refere-se ao trabalho de cunho político e articulador com as chefias departamentais, para a apresentação do Plano de gestão e compreensão da proposta de trabalho do grupo, bem como da proposta de fluxo de trabalho elaborado com a CG. Outra ação importante é propor a realização de cursos, palestras e leituras que enfoquem aspectos específicos da gestão de ensino e de outros temas como, por exemplo, os relativos ao projeto pedagógico, ao planejamento do processo ensino-aprendizagem, enfim ao acompanhamento do currículo. Nesse sentido, é essencial a articulação com o Grupo de Apoio Pedagógico do Campus da USP de Ribeirão Preto (GAPRP) ${ }^{1}$, para desenvolver ações e atividades que têm como objetivo incentivar a participação dos docentes universitários nos encontros abertos de discussão sobre os saberes pedagógicos que dizem respeito à docência na universidade.

4. Formação pedagógica do corpo docente: Apesar desse eixo relacionarse também à gestão do ensino, nós o colocamos em destaque, dada sua importância. Investir na formação pedagógica do corpo docente, condição diferencial para promover processos de mudanças na graduação, não é apenas tarefa da $\mathrm{CoC}$, mas como responsável pela gestão pedagógica dos cursos de licenciatura, é importante que as CoCs estimulem a formação docente.

4.1 Ação: Estímulo à formação pedagógica dos docentes do curso de licenciatura.

4.2 Operacionalização: Efetuar o levantamento nos cursos acerca dos docentes que fizeram o Curso Pedagogia Universitária, propondo um encontro com eles para estabelecer uma parceria mais efetiva nos momentos de reuniões pedagógicas entre o "colegiado" de curso. Em parceria com o GAPRP, incentivar a participação dos docentes nos encontros abertos de discussão de temas pedagógicos e propor cursos/palestras, conforme as necessidades específicas. 
A gestão de um curso universitário representa um duplo desafio: de um lado, o acompanhamento e a atualização do PPP, bem como a tomada de decisão acerca das questões que vão surgindo no decorrer do processo; de outro, a agregação de docentes, estudantes e demais colegas gestores visando a um processo de participação democrática. A gestão possibilita a reflexão e participação, requerendo sujeitos mais criativos, participativos e integrados a um projeto de sociedade e de educação universitária que compreende uma pluralidade de exigências, as quais passam pelos saberes disciplinares, culturais, afetivos, técnicos, psicológicos, sociológicos, metodológicos e políticos. A democratização do conhecimento, a competência profissional e as múltiplas dimensões da processualidade docente evidenciam a concepção de gestão como alternativa de abertura às práticas educativas, às práticas sociais integradas.

Apesar de avanços institucionais na universidade seja pelo estabelecimento de um Programa de Formação de Professores ou pela definição do papel que as CoCs devem desempenhar, ressaltamos que temos um longo caminho a percorrer no que concerne à gestão de cursos de graduação na universidade, considerando alguns limites que, neste momento, ainda são considerados desafios. Um desses limites refere-se à multiplicidade de papéis que o professor universitário deve desempenhar no campo do ensino, da pesquisa e da extensão. Por outro lado, no cotidiano da universidade, a comunicação por meio eletrônico impõe aos professores inúmeras demandas, num processo que nem sempre se separam as ações importantes das desnecessárias. Sem dúvida, também esse fato dificulta o processo de gestão.

PEDAGOGICAL MANAGEMENT OF TEACHER FORMATION COURSES AT A PUBLIC UNIVERSITY: CONTRIBUTIONS TO A REFLECTION

ABSTRACT:This paper, a reflection on experiences of coordinating undergraduate teacher formation courses in the context of a public Brazilian university, focuses on what facilitates and limits the building of a collective process where the courses' pedagogical projects are a management tool. Certain legal provisions and teacher training courses focusing on the theme of management, sponsored by the university, are included in what facilitates the process and are then analyzed. Included among the hindrances are difficulties in undertaking collective work, the excessive workload of teachers, the conditions under which undergraduate courses are offered, and the promotion and priority of research at the expense of teaching.

KEYWORDS: Pedagogical Management in Higher Education. Coordination of undergraduate courses. Curriculum. Teacher formation. 


\section{NOTA}

1. O GAPRP/USP, institucionalizado pela Portaria Interna da Pró-Reitoria de Graduação n. 4/2004, foi idealizado pelos presidentes das Comissões de Graduação das Unidades do Campus de Ribeirão Preto/USP, preocupados com a melhoria do ensino, o que vem ao encontro da política de valorização da graduação nesta Universidade, relacionandose às diretrizes políticas nacionais e internacionais voltadas ao ensino superior.

\section{REFERÊNCIAS}

AFONSO, A. J. Reforma do Estado e Políticas Educacionais: alguns tópicos para discussão. Anuário GT Estado e Política Educacional: políticas, gestão e financiamento da educação. In: REUNIÃO ANUAL DA ANPED, 23, Caxambu, 2000. Caxambu: ANPED, 2000, p. 15-36. 1 CD.

BRASIL. Conselho Nacional de Educação. Documento Referência para o Fórum Nacional de Educação Superior. Brasília: CNE, 2009.

BRASIL. Ministério da Educação. Documento síntese do Fórum Nacional de Educação Superior (FNES). Conselho Nacional de Educação. Câmara de Educação Superior. Secretaria de Educação Superior. Brasília: MEC/CNE/SESU, 2009.

BRASIL. Conselho Nacional de Educação. Portarias CNE/CP n. 7/2009 e n. 8/2009, aprovado por unanimidade na sessão plenária do dia 4 de agosto de 2009, contendo "Indicações para subsidiar a construção do Plano Nacional de Educação 2011 - 2020". Brasília: CNE, 2009.

BRASIL. Ministério da Educação. Documento Referência da CONAE. Brasília: MEC/ SESU, 2009.

BRASIL. Lei n. 9394, de 20 de dezembro de 1996. Estabelece as Diretrizes e Bases da Educação Nacional. Brasília: Senado Federal, 1996.

BRASIL. Ministério da Educação. Sinopse Estatística da Educação Básica. Censo escolar 2006. Brasília: INEP, 2007.

BRASIL. Lei n. 10.172, de 9 de janeiro de 2001. Plano Nacional de Educação. Brasília: MEC, 2001.

BRASIL. Ministério da Educação. Plano Nacional de Graduação. Brasília: MEC, 1999.

BRUNO, L. Poder e administração no capitalismo contemporâneo. 4. ed. In: OLIVEIRA, D. A. (Org.). Gestão Democrática da Educação. Petrópolis: Vozes, 2002.

CUNHA, M. I. Inovações Pedagógicas: o desafio da reconfiguração de saberes na docência universitária. In: PIMENTA, S.; ALMEIDA, M. I. Pedagogia Universitária. São Paulo: EDUSP, 2009.

CHAUÍ, M. A universidade pública sob nova perspectiva. In: REUNIÃO ANUAL DA ANPED, 26, 2003, Poços de Caldas. Anais. Poços de Caldas: ANPED, 2003. 1 CD. 
CURY, C. R. J. Por um Plano Nacional de Educação: Nacional, Federativo, Democrático e Efetivo. Texto elaborado para o Conselho Pleno do Conselho Nacional de Educação, em março de 2009. Disponível em: http://portal.mec.gov.br/dmdocuments/pne_200809. pdf > . Acesso em: jun. de 2010.

DALE, R. Globalization and education: demonstrating a common world educational culture or locating a globally structured educational agenda? Educational Theory, $v$. 50, n.4, p. 427-448, 1999.

DELANTY, G. Challenging Knowledge: the university in the knowledge society. Londres: Society for Research Into Higher Educat Press, 2001.

Declaração da Conferência Regional de Educação Superior na América Latina e no Caribe (CRES). Cartagena de Índias, 2008.

FERREIRA, N. S. A gestão de educação e as políticas de formação de profissionais da educação: desafios e compromissos. In: FERREIRA, NSC. (Org.). Gestão democrática da educação: atuais tendências, novos desafios. 5. ed. Petrópolis: Vozes, 2006.

FRIGOTTO, G.; CIAVATTA, M. (Orgs.). Teoria e educação no labirinto do capital. Petrópolis: Vozes, 2001.

LÜCK, H. Gestão Educacional. 5. ed. Petrópolis: Vozes, 2010.

MOROSINI, M. C.; MOROSINI, L. Pedagogia Universitária: entre a convergência e a divergência na busca do alomorfismo. UNIrevista, São Leopoldo, v.1, n. 2, p. 1-10, 2006.

NEAVE, G. On the cultivation of quality, efficiency and enterprise: an overview of recent trends in higher education in Western Europe. 1986 - 1988. European Journal of Education, v. 23, n. 1/2, p. 7-23, 1999.

SABADIA, J.A.B. O papel da coordenação de curso: a experiência no ensino de graduação em geologia na Universidade Federal do Ceará, Fortaleza. Revista de Geologia, v. 11, p. 23-29, 1998.

SANTOS, B. S. (Org.). A globalização e as ciências sociais. 3. ed. São Paulo: Cortez, 2004.

SGUISSARDI, V. A universidade neoprofissional, heterônoma e competitiva. In: REUNIÃO NACIONAL DA ANPED, 24, Poços de Caldas, 2004. Rio de Janeiro: D,P \& A.,2004. $1 \mathrm{CD}$.

UNIVERSIDADE DE SÃO PAULO. Pró-Reitoria de Graduação. Comissão Permanente dos Cursos de Licenciatura. Programa de Formação de Professores da USP. São Paulo: USP, 2004.

. Pró-Reitoria de Graduação, Resolução CoG n. 5500. Estabelece normas para o funcionamento das Comissões de Coordenação de Cursos. São Paulo: USP, 2009.

VEIGA, I. P. A. (Org.). As dimensões do Projeto Político-Pedagógico. Campinas: Papirus, 2001.

ZABALZA, M. A. O ensino universitário: seu cenário e seus protagonistas. Porto Alegre: Artmed, 2004. 
Gláucia Maria da Silva é Professora doutora do Departamento de Química da Faculdade de Filosofia, Ciências e Letras da USP de Ribeirão Preto.

E-mail: slauciams@ffclrp.usp.br

Noel Prestes Padilha Rivas é Professora doutora do Departamento de Psicologia e Educação da Faculdade de Filosofia, Ciências e Letras da USP de Ribeirão Preto.

E-mail: noerivas@ffclrp.usp.br 



\title{
ENSINO E PESQUISA: DESAFIOS E POSSIBILIDADES PARA DOCENTES UNIVERSITÁRIOS INICIANTES*
}

\author{
Beatriz Maria Boéssio Atrib Zanchet, \\ da Universidade Federal de Pelotas
}

\begin{abstract}
Resumo: Como docentes iniciantes, na carreira universitária, enfrentam os desafios da passagem de uma formação que privilegia a pesquisa para uma prática eminentemente de docência é o foco da discussão apresentada. A pesquisa utilizou para a coleta de dados entrevistas semiestruturadas com docentes iniciantes, mestres e/ ou doutores, que atuam em diferentes áreas do conhecimento e exercem a docência em diferentes universidades. A partir da análise dos dados foi interessante perceber que os docentes reconheceram, dentre outros aspectos, que a pesquisa ajuda-os a aprender a pensar e a observar as coisas sob outros ângulos. Isso acaba gerando outros conhecimentos e assim vão enfrentando os desafios requeridos para ensinar.

PalavRAs-Chave: Professores universitários iniciantes. Ensino superior. Ensino e pesquisa.
\end{abstract}

As políticas educacionais brasileiras definidas no panorama socioeconômico mundial enfatizaram elementos que gravitam ao redor da economia e do redimensionamento do capitalismo contemporâneo, da redefinição do papel do Estado, dos impactos das transformações tecnológicas, dentre outros. Nesse quadro, surge a emergência de uma força de trabalho que seja capaz de ficar atenta ao cenário mundial, pois novas qualificações vão sendo delineadas e exigidas para a vida em sociedade. Mais do que desempenhar funções cognitivas e estar em processo de aprendizagem permanente, solicita-se para a educação, um padrão de atitude que envolva a cooperação, a autonomia, a capacidade de comunicar-se e trabalhar em equipe.

\footnotetext{
* Artigo recebido em 01/08/2011 e aprovado em 04/10/2011.
} 
Os debates sobre a qualidade da educação assumiram o novo marco como referência. Evidenciada nos debates e agendas de diferentes segmentos da sociedade, a educação é alçada a um patamar estratégico de promoção e desenvolvimento de novas habilidades e competências para fazer frente ao mundo do trabalho. O discurso oriundo do mercado, assumido na educação, foi responsável por importantes transformações na estrutura curricular e na definição do papel dos professores, bem como nos mecanismos de gestão dos sistemas educativos. Nota-se, de forma bastante clara, nos documentos oficiais, a incorporação da terminologia empresarial ao mundo da educação.

O mesmo discurso coloca desafios à universidade, que, apesar de continuar a ser a instituição por excelência de conhecimentos científicos, começou a perder a hegemonia que tinha e foi se transformando, pouco a pouco, num alvo fácil de crítica social. Como explica Santos (2004, p. 39), "na última década começaram a alterar significativamente as relações entre conhecimento e sociedade e as alterações prometem ser profundas a ponto de transformarem as concepções que temos de conhecimento e de sociedade". O autor aponta que a comercialização do conhecimento científico é o lado mais visível dessas alterações, embora isso seja apenas a ponta do iceberg, pois as transformações em curso são de sentido contraditório e as implicações são múltiplas, inclusive de natureza epistemológica.

O conhecimento científico foi, ao longo do século XX, predominantemente disciplinar, o que gerou um processo de produção científica pouco relacionado às premências da sociedade. Nessa lógica, os pesquisadores, na maioria das vezes, são aqueles que definem os problemas científicos para os quais devem buscar solução, definindo sua relevância e estabelecendo o método e o ritmo da pesquisa. Para Santos (2004), esse é um conhecimento homogêneo na medida em que agentes participantes de sua produção têm em comum os mesmos objetivos de produção de conhecimento, têm a mesma formação e a mesma cultura científica e fazem-no segundo hierarquias organizacionais bem definidas. O conhecimento produzido na lógica desse processo provoca a distinção entre conhecimento científico e outros conhecimentos, e, consequentemente, faz distinção entre ciência e sociedade.

Entendemos que a organização universitária e o ethos universitário foram moldados por este modelo de conhecimento. Entretanto, as alterações ocorridas nas últimas décadas desestabilizaram os referenciais que prevaleciam para pensar o conhecimento e passaram a apontar para a emergência de outra lógica para a sua produção. Santos (2004, p. 41) designa essa transição por passagem do conhecimento universitário para o conhecimento pluriversitário. Explica o autor que o conhecimento pluriversitário é contextual na medida 
em que o princípio organizador da sua produção é a aplicação que lhe pode ser dada. Nessa perspectiva, aponta Santos que

como essa aplicação ocorre extramuros, a iniciativa da formulação dos problemas que se pretende resolver e a determinação dos critérios da relevância destes é o resultado de uma partilha entre pesquisadores e utilizadores. É um conhecimento transdisciplinar que, pela sua própria contextualização, obriga a um diálogo ou confronto com outros tipos de conhecimento, o que o torna internamente mais heterogêneo e mais adequado a ser produzido em sistemas abertos menos perenes e de organização menos rígida e hierárquica. (SANTOS, 2004, p. 41)

No entanto, é preciso estar atento, pois o conhecimento pluriversitário tem apresentado a sua concretização mais consistente nas parcerias universidade - indústria e, portanto, sob a forma de conhecimento mercantil.

Diante dessas transformações, observamos que a universidade fica exposta a exigências contrapostas, mas com o efeito convergente de desestabilizarem a sua institucionalidade atual. Segundo o autor, a instabilidade causada pelo impacto destas pressões contrapostas cria impasses, tornando evidente que as exigências de maiores mudanças vão frequentemente de par com as maiores resistências à mudança.

Percebe-se, assim, que a passagem do conhecimento universitário para o conhecimento pluriversitário é, portanto, um processo muito mais amplo que a mercantilização da universidade e do conhecimento por ela produzido.

Nessa perspectiva, o conhecimento não pode ser proposto como algo acabado, mas como produto determinado e situado dentro de relações sociais específicas e, ao mesmo tempo, dependente de determinada visão de mundo. As exigências sobre as universidades superaram sua capacidade de resposta, o financiamento público diminui, ficando cada vez mais dependente dos resultados, o conhecimento excede aos recursos e se cria uma grande demanda de toda ordem. Vale ressaltar, também, que a competitividade no mundo do trabalho vem abalando a organização acadêmica, ainda apegada às carreiras tradicionais. A organização interna dos currículos, baseada em competências bem definidas, dá lugar a novas propostas. Emergem discursos com ênfase na interdisciplinaridade, na flexibilização e em outros conceitos nessa direção que, até há pouco tempo, eram raros na educação superior. Esta condição colide com a trajetória de formação da maioria dos professores, porque se distancia de suas histórias. Também exige uma apropriação teórica que grande parte não possui, dificultando o entendimento de propostas que tentam atender esses discursos. Como a implementação das propostas 
depende do trabalho cotidiano do professor, infere-se que o sucesso ou fracasso do sistema escolar são de sua responsabilidade. Nesse sentido, a prática pedagógica dos professores precisa ser acompanhada e controlada, pois, na lógica administrativa, essas são as estratégias eficazes para reforçar sua responsabilização pelos resultados dos sistemas educacionais.

No Brasil, em relação à formação de professores universitários, a Lei de Diretrizes e Bases (1996) refere-se a uma "preparação" a ser desenvolvida nos Programas de Pós-Graduação strictu senso, de todas as áreas do conhecimento. Esses Programas, em geral, não focalizam sua atenção nos saberes da docência, privilegiando especialmente as habilidades de pesquisa, que é considerada um fundamental atributo da qualidade da educação superior. Os processos seletivos que envolvem concursos públicos avaliam o domínio do conhecimento específico do candidato para assumir o cargo de docente. Se os conhecimentos específicos são considerados principais, como afirma Barco (1999), "a demonstração das capacidades docentes fica restrita ao espaço de um simulacro: se 'dá' uma aula na audiência de alunos, ou se explica como se procederia com os alunos, dos quais se desconhecem as características, apelando-se, portanto, para sua abstração". A autora afirma ainda que o concurso aparece, assim, como "um rito de passagem" (p. 153), referindo-se à transformação de qualquer profissional em professor a partir desse processo seletivo.

O peso das produções científicas e dos títulos acadêmicos assumiu maior expressão. Na maioria dos casos, os títulos de mestre e doutor constituem condição de inscrição. Esse cenário explicita que o perfil de pesquisador passa a se constituir no vetor da qualidade da educação superior e, portanto, da condição docente. Vai se consagrando o perfil de um professor que se distancia da representação histórica do quem sabe fazer, sabe ensinar, passando para a equação que pressupõe que quem sabe pesquisar, sabe ensinar (CUNHA, 2010).

Tem-se hoje um corpo docente ingressante constituído na sua maioria de jovens doutores que realizaram uma formação acadêmica com sucesso e imediatamente ingressam na carreira docente. Se indagados sobre o motivo desta escolha, mencionam, sobretudo, que escolhem a universidade por ser o lugar de fazer pesquisa. Percebemos que esse perfil de docente também corresponde a uma concepção de qualidade para a educação superior, aquela que destaca a investigação e a produção do conhecimento como eixos principais de sua condição acadêmica.

Assim, a tensão apresentada indica que, na expectativa da sociedade, o papel da universidade é ensinar bem aos jovens a serem competentes e 
competitivos profissionalmente, assegurando-lhes as ferramentas básicas para serem incluídos no mundo do trabalho. A pesquisa se estabelece como pano de fundo dessa expectativa, porque qualifica e prestigia a formação profissional requerida, sendo reconhecida como requisito fundante da profissão universitária. Cada professor está preparado para abordar os temas que pesquisa, num recorte de sua especialidade. Entretanto, na dimensão do ensino, os saberes próprios da profissão docente Ihe são alheios. Sem desconsiderar a importância da formação investigativa na trajetória de jovens doutores, é difícil imaginar que eles possam fazer rupturas epistemológicas e correr riscos de desenvolver uma pedagogia que certamente se afasta de suas trajetórias estudantis.

Como, então, trabalhar com a tensão que envolve ensino e pesquisa no âmbito dos currículos universitários e nas práticas de ensinar e aprender que deveriam implementar? É possível afirmar que a formação em pesquisa é dispensável na educação superior? Entender como os professores iniciantes na carreira universitária percebem os saberes da pesquisa podendo ou não contribuir para suas ações pedagógicas e para o ensino que desenvolvem tornou-se objeto da pesquisa aqui apresentada.

\section{O PERCURSO INVESTIGATIVO: APROXIMAÇÕES COM O CAMPO EMPÍRICO}

Várias são as questões que nos mobilizaram e deram rumo à pesquisa. Dentre elas citamos: Como os processos de ensino e pesquisa vão se constituindo para o docente iniciante? Como percebem, sendo pesquisadores habilitados, a relação entre ensino e pesquisa? Como os saberes da pesquisa os ajudam a ser professores? Que saberes valorizam mais na docência universitária? Como aprendem a fazer mediações entre ensino e pesquisa?

O primeiro delineamento do campo empírico se deu por meio da definição das Universidades que poderiam participar da pesquisa. Para tal, consideramos como critérios: localização geográfica em relação à atuação dos pesquisadores participantes do grupo (RS e PR) e dependência administrativa (públicas e privadas). A partir desses critérios, buscamos nas Universidades Federal de Pelotas (UFPel), Universidade do Vale do Rio dos Sinos (UNISINOS), Universidade Federal do Pampa (UNIPAMPA) e Universidade Federal do Paraná (UFPr) - setor Litoral - a indicação de professores que poderiam constituir a amostra através do contato com os coordenadores dos diferentes Cursos dessas Instituições de Ensino Superior (IES). Após apresentarmos a pesquisa, solicitamos aos coordenadores que nos fornecessem os nomes dos professores iniciantes - com até cinco anos na carreira docente universitária - e oriundos de diferentes profissões. Ao recebermos a listagem com os nomes 
dos professores que atendiam esses critérios, fizemos um mapeamento inicial dos docentes e de suas respectivas áreas de atuação. No segundo momento, conversamos com os professores indicados para saber a sua disponibilidade em participar da pesquisa através de uma entrevista semiestruturada.

Constituímos uma amostra, a partir da disponibilidade dos docentes, com 27 professores ${ }^{1}$ que atuam em diferentes Cursos.

A entrevista semiestruturada é composta por vários eixos temáticos, como por exemplo: motivos/razões para ingressar na docência universitária (como se tornou professor universitário); experiências iniciais na profissão docente; formas de apoio encontradas na IES ou no Departamento ou no Curso; relação com os estudantes; lugar de formação do professor universitário; saberes específicos para a docência e relação entre as atividades de pesquisa e atividades da docência. As questões foram organizadas de tal forma que nos permitisse ter um panorama geral sobre as ideias de cada respondente em relação a esses tópicos. Além disso, essas questões foram elaboradas levando em consideração os estudos e a trajetória realizada pelo grupo, como também as pesquisas da área, tais como as de Cunha (1998; 2003; 2005; 2006); Pimenta (1999), Barnett (2008); Mayor Ruiz (2009); Zabalza (2004), Marcelo Garcia (1999), entre outros. A análise dos dados considerou os princípios da análise de conteúdo, pois esse enfoque constitui-se em um conjunto de técnicas de análise de comunicação "visando obter, por procedimentos sistemáticos e objetivos de descrição do conteúdo das mensagens, indicadores que permitam a inferência de conhecimentos relativos às condições de produção/ recepção destas mensagens" (Bardin,1979, p. 42).

O ENSINO E A FORMAÇÃO PARA A PESQUISA: O QUE EXPRESSARAM OS PROFESSORES

Há um pressuposto inquestionável de que a pesquisa qualifica o ensino e sobre ele há uma concordância implícita que todos ratificamos. Mas será que essa relação se faz de forma tão linear? Sempre que há pesquisa haverá ensino de qualidade? Os saberes que sustentam a pesquisa serão suficientes para a realização de práticas pedagógicas significativas?

Essas questões são instigantes para analisar o fenômeno da educação superior na contemporaneidade e se tornam mais intensas quando se analisa o caso dos jovens doutores que acorrem à carreira docente na expectativa de encontrar um espaço de profissionalização. Estimulados a realizar seus cursos de mestrado e doutorado, aprenderam a trajetória da pesquisa e, em geral, aprofundam um tema de estudo verticalmente, num processo progressivo de especialização. Quando se incorporam à educação superior nesses tempos de interiorização e massificação, descobrem que deles se exige uma gama 
maior de saberes, em especial para o exercício da docência. Percebendo a docência como ação complexa, terão de dominar o conhecimento disciplinar nas suas relações horizontais, em diálogo com outros campos que se articulam curricularmente, ultrapassando a visão linear do conhecimento no qual se aprofundaram na sua verticalidade.

Assim, percebe-se que essa situação torna-se preocupante na universidade e é acrescida das tensões estabelecidas entre a pesquisa e o ensino, entre a produção acadêmica e a gestão ou entre a pesquisa básica e a extensão. Nesse cenário, há a aposta de que a formação pedagógica do docente universitário seja incentivada para estimular os professores a construírem as bases de sua identidade profissional docente, contemplando a possibilidade do desenvolvimento de um trabalho conjunto para a construção das abordagens pedagógicas que precisam constituir.

Ao serem questionados sobre o ensino que desenvolvem, suas respostas apontaram, como condição importante para o exercício da docência no ensino superior, a formação de sua base profissional mesmo que ela não seja voltada para o ensino. Disse-nos um entrevistado que "eu vejo que se você conhece o assunto que vai trabalhar, uma coisa é você ter uma base e ter o conhecimento sobre aquele assunto que você vai dar aula, não adianta você querer dar aula de uma coisa que você não preparou, que você não tem convívio. $O$ saber está ligado à prática do professor e à pesquisa que ele desenvolveu" (B2).

Os entrevistados mostraram uma preocupação relacionada à formação pedagógica, pois nos seus cursos de mestrado e/ou doutorado não tiveram oportunidades de discutir o ensino. Afirmaram que esses cursos estão muito voltados para a formação do pesquisador e pouca ou nenhuma preocupação é vislumbrada com a finalidade da preparação do professor para enfrentar os desafios da sala de aula. Explicaram que o curso de graduação foi balizado na perspectiva técnica e posteriormente a pós- graduação foi alicerçada na investigação de problemas muito específicos; logo, esses aspectos limitaram significativamente sua prática pedagógica, como relata um professor: "não sei absolutamente nada de didática, nunca discuti um autor. Tudo que aprendi é porque observei alguém fazendo, é porque troco figurinhas com os alunos para tentar achar o caminho" (A1).

Os professores explicaram que a docência é um exercício que pode ser aprimorado, mesmo que no início ele seja repleto de dificuldades. Argumentam que, se o professor gosta do que está fazendo e tem interesse na docência, vai melhorando e superando as dificuldades encontradas. Afirmaram que ter o domínio consistente do conteúdo é condição mínima 
para o bom desempenho de sua função. Os docentes universitários, segundo Pimenta e Anastasiou (2008, p. 198), desenvolvem "habilidades referentes ao método de pesquisa que conta com especificidades bem diferentes do método de ensino".

Perguntados sobre a necessidade de saberes específicos para o ensino, as respostas apontaram para a importância do conhecimento da relação ensino-aprendizagem, das relações pedagógicas para tentarem interagir da melhor forma com os estudantes. A compreensão dessas relações pode ajudá-los a ensinar melhor os conteúdos e, talvez, ajudálos a desenvolver melhor o processo de avaliação com seus alunos. Os professores salientaram, vale destacar, que seria importante contemplar um aprofundamento nas questões da formação específica da área aliando-as às da formação pedagógica e às que correspondem à pesquisa. Mesmo que os professores tenham mencionado essa condição, é necessário ressaltar que seus cursos de graduação os habilitaram para o exercício de uma profissão que não é a docência.

Nossos entrevistados alertaram que os concursos para professores universitários não exigem essa formação. Um deles disse que "a formação, no caso de mestre ou doutor, ela tem uma lacuna na área pedagógica, no ensino, e até eu mesmo acho que há muitos critérios, por exemplo, num concurso, em que um dos principais aspectos é a publicação de artigos científicos, mas isso não é garantia de que o professor, sendo um grande pesquisador, vai ser um bom professor" (B3).

Torna-se importante retomar o dilema entre a formação para a docência e a formação para a pesquisa que é explicitado por Zabalza (2004), pois, para esse autor, nas universidades existe a orientação de desenvolver atividades tanto de ensino como de pesquisa. Entretanto, a cultura universitária tem atribuído um maior status acadêmico à pesquisa e lhe dado prioridade. Segundo o autor,

o que normalmente é avaliado nos concursos de ingresso e promoção são os méritos das pesquisas; o que os professores e seus departamentos tendem a priorizar por causa dos efeitos econômicos e do status são as atividades de pesquisa; o destino prioritário dos investimentos para formação do pessoal acadêmico, em geral, é orientado principalmente para a formação em pesquisa (muitas vezes, é administrado pelas pró-reitorias de pesquisa) e assim sucessivamente. (ZABALZA, 2004, p. 154)

É comum, na universidade, a concepção de que para ser um bom professor universitário, o mais importante é ser um bom pesquisador, pois este possui uma visão mais sistemática e um maior conhecimento do campo 
científico. Essa condição eleva a atividade de pesquisa a um grau intelectual superior à atividade de ensino e parece fazer parte da cultura docente. Sobre isso disse-nos um entrevistado que "um bom professor não necessariamente é um bom pesquisador e vice-versa, embora tenhamos situações em que ambos os casos ocorram. Mas eu acho que não existe uma correlação direta entre isto" (A3).

No entanto, a cultura docente não é tributária apenas da experiência historicamente acumulada nos padrões de atuação desse grupo profissional; ela é influenciada pelas pressões e expectativas externas, pelos requerimentos situacionais dos sujeitos envolvidos. Essa característica põe em evidência a articulação entre a cultura docente e o processo social mais amplo, isto é, sua dimensão ideológica e política e, por isso mesmo, não neutra. Podemos dizer que a cultura docente é um fator importante a considerar em todo projeto que se pretende implantar na universidade em geral, e nos cursos, em particular. Um professor reafirma essa condição quando diz que "hoje em dia todo mundo quer ser pesquisador, é difícil tu encontrar um professor que entre na universidade que queira ser extencionista, por exemplo, são raros, porque a gente tem na verdade proposições macro que sinalizam para isso" (para a pesquisa) (B3).

Podemos observar que a universidade teve de atribuir um maior status acadêmico à pesquisa até transformá-la no componente básico da identidade e do reconhecimento do docente universitário. Além disso, fez com que o ensino se transformasse em uma atividade secundária dos docentes. Muitas vezes, na universidade, aceita-se que a pesquisa constitua um grau de desenvolvimento intelectual superior, uma oportunidade para ver os assuntos pesquisados de forma mais rigorosa e sistemática, um maior conhecimento dos temas que transitam nos campos científicos. Em contrapartida, essa argumentação é fraca se analisada sob a ótica do ensino. Disse-nos um professor que, em alguns casos, "as pesquisas abastecem de certa forma um pouco o que estou passando hoje para os alunos ... eu estou conseguindo, de certa forma, explorar alguns dos resultados, das coisas que a gente vem trabalhando, com meus alunos dentro da sala de aula" (A3). Outro entrevistado afirmou que "a pesquisa alimenta a prática docente com indagações e produção de conhecimento, a extensão também. Procuro sempre trabalhar de forma integrada. Conhecer a realidade através de pesquisa, desenvolvendo o senso crítico dos alunos no ensino e trabalhando na realidade através da extensão" (B1,5). Os docentes iniciantes entrevistados explicaram que a especialidade e o aprofundamento de um tema específico de sua área poderá "atrapalhar" sua condição de professor. Nesse sentido, 
um deles afirmou que "meu doutorado foi muito específico e me atrapalhou, porque a minha pesquisa é muito direcionada, é com uma família, a Botânica, e agora eu dou aula de tudo. Então muita coisa eu tive que voltar a estudar, retomar para entrar numa sala de aula" (A1).

As afirmações dos entrevistados nos remetem ao que Zabalza (2004, p. 11) explica sobre a docência, pois, para o autor, "conhecer bem a própria disciplina é uma condição fundamental, mas não é o suficiente". E complementa explicando que o trabalho docente envolve vários tipos de conhecimentos e competências que necessitam de uma preparação específica. O autor diz, também, que a capacidade intelectual do docente e a forma como abordará os conteúdos são muito distintas de como o especialista o faz. Esta é uma maneira de se aproximar dos conteúdos ou das atividades profissionais pensando em estratégias para fazer com que os alunos aprendam. Essa posição é ratificada na expressão de um docente quando disse que "um dos desafios é sempre estar me perguntando se o conteúdo e a metodologia que a gente está utilizando, a didática em sala de aula está atendendo a questão do aluno até para o mercado de trabalho, tanto é que é uma questão que eu estou me perguntando e que talvez seja o meu desafio de doutorado, trabalhar a formação do assistente social, então esse é o meu desafio. Eu não diria que é uma dificuldade, eu vejo mais como um desafio, o que eu estou ministrando em sala de aula é realidade para a profissão?" (A4).

Quando questionamos os docentes sobre a construção de saberes para a docência a partir do desenvolvimento de pesquisas, alguns deles afirmaram que é importante a decisão sobre o que podem e devem pesquisar. Um entrevistado disse que "pode mesmo que da sala de aula, em função da própria interação com os alunos saia uma proposta, uma ideia de pesquisar e isso aí tem que ser uma coisa muito harmoniosa, não pode ter proposições entre pesquisa e ensino paralelas e distantes. Eu acho que a gente tem que tentar aproximá-las [...] é bastante possível sim" (B3).

É interessante salientar o que um docente disse a respeito da pesquisa: "eu particularmente gosto muito da pesquisa aplicada, não gosto de situações que são meramente contribuições científicas, pois essa aplicação prática é inviável. Eu gosto de tentar interagir numa situação que a gente possa aplicar ela realmente na prática. Então se a gente conseguir levantar ou executar experimentos, pesquisas com esse enfoque, eu acho que naturalmente elas vão para a sala de aula depois, porque no momento que tu tens essas informações, tu vais poder usá-las no contexto da tua disciplina e então ter essa troca com os alunos, interagir" (B3). Outro professor enfatizou: "para mim, o professor é, ele não deixa de ser, ele é pesquisador, ele é docente, 
e ele é o que vai fazer extensão, o que vai passar conhecimento ou para o aluno ou para a sociedade", e reiterou afirmando que "para ser pesquisador, ser um bom pesquisador, ele necessitaria de um pouco de docência, porque a meu ver é mais importante a pergunta do que a resposta e de que forma tu desenvolves uma boa pergunta para realizar uma boa pesquisa? É na prática docente, mentes jovens, dúvidas novas, perguntas boas" (B2).

Nessa perspectiva, entendemos as especiais exigências intelectuais mencionadas por Brown e Atkins (apud Zabalza, 2004) ao afirmarem que

além de conhecer os conteúdos os docentes devem ser capazes de: analisar e resolver problemas; analisar um tópico até detalhá-lo e torná-lo compreensível; observar qual é a melhor maneira de se aproximar dos conteúdos e de abordá-los nas circunstâncias atuais; selecionar as estratégias metodológicas adequadas e os recursos que maior impacto possam ter como facilitadores da aprendizagem; organizar as ideias, a informação e as tarefas para os estudantes. (p. 111)

Como em qualquer outra profissão, é importante uma educação continuada que, no caso da docência, envolve a dimensão da pesquisa e a dimensão do ensino. A docência será uma atividade profissional na medida em que essa condição se materializar. A atividade de ensino exige a ressignificação dos conhecimentos teóricos em contextos de práticas que são peculiares e localizadas. Os professores universitários enquanto profissionais, sejam iniciantes ou mais experientes, precisam assumir uma atitude de reflexão constante sobre suas práticas, teorizando os fundamentos de suas decisões pedagógicas.

\section{CONSIDERAÇÕES COMPLEMENTARES}

Algumas vezes, nas universidades, não há coincidência entre conteúdos de pesquisa e conteúdos da docência. No entanto, foi interessante perceber que os docentes reconheceram que a pesquisa faz, muitas vezes, com que o pesquisador desenvolva atividades de professor, pois ela ajuda-os a aprender a pensar e a observar as coisas sob outros ângulos, o que acaba gerando outros conhecimentos. Mesmo que nossos interlocutores tenham mencionado que durante seus cursos de mestrado e/ou doutorado aprenderam metodologia para fazer pesquisa e não aprenderam metodologia de ensino, entendemos que expressaram, nas suas falas, preocupação com uma formação que os ajude a enfrentar os desafios da docência, pois de qualquer forma, as funções de docência e de pesquisa precisam de formação. 
A incorporação ao mundo da pesquisa, na maior parte das vezes, ocorre em um contexto mais específico e regulado. Zabalza (2004, p. 155) argumenta que as competências e qualidades profissionais para o ensino e para a pesquisa são diferentes.

Torna-se importante, no contexto da formação dos docentes iniciantes na carreira universitária, refletir sobre sua formação pedagógica, além de buscar compreender os processos que esses docentes vivenciam para construir saberes para o ensino.

Concordamos com Pimenta e Anastasiou (2008) quando explicam que a docência na universidade"configura-se como um processo contínuo de construção da identidade docente e tem por base os saberes da experiência, construídos no exercício profissional mediante o ensino dos saberes das áreas do conhecimento". As autoras afirmam também que para que a identidade de professor se configure, é necessário que o docente ponha-se em "condições de proceder à análise crítica desses saberes da experiência construídos nas práticas, confrontando-os e ampliando-os com base no campo teórico da educação, uma identidade epistemológica decorrente de seus saberes científicos e os de ensinar" (p. 88). Além disso, salientamos que a tarefa fundamental do professor universitário iniciante, durante seus primeiros anos de docência, deveria ser a aprendizagem, focando seu pensamento e seu comportamento nas demandas do ensino. Ou seja, é importante aprender a linguagem da prática do ensino. Nas palavras de Howey (apud, MAYOR RUIZ, 2001), encontramos o que consideramos ser necessário nessa etapa de iniciação à docência:

La tarea fundamental del profesor principiante durante sus primeros años de docencia debe ser el aprendizaje, dirigido a enfocar su pensamiento y sus comportamientos hacia las demandas de la enseñanza, es decir, aprender el lenguaje de la practica. (p. 3)

Nessa perspectiva, acreditamos que os docentes iniciantes talvez deveriam dedicar-se, nos primeiros anos da carreira, a desempenhar funções que os ajudassem a aprender e que destinassem mais tempo para a sua formação como professor.

TEACHING AND RESEARCH: CHALLENGES AND POSSIBILITIES FOR BEGINNER UNIVERSITY PROFESSORS

ABSTRACT: How professors at the start of a university career face the challenges of moving from an education process focused on research to one that mainly involves teaching practice is the theme of this discussion. Semi-structured interviews with beginner 
professors, Masters and PhDs, working in different scientific fields and lecturing in different universities were used to collect data. From an analysis of the data it was interesting to notice that teachers recognized that, among other aspects, research helps them learn how to think and observe from other perspectives, thus providing them with knowledge to face the challenges of teaching.

KEYWORDS: Beginner university professors. Higher education. Teaching and research.

\section{NOTA}

1. A amostra ficou assim distribuída: 9 (nove) professores da UFPel, 6 (seis) professores da UNIPAMPA, 6 (seis) professores da UNISINOS e 6 (seis) da UFPr - setor Litoral. Os professores serão identificados pelas letras $A$ - se for professora e B - se for professor seguido de um número que indica o tempo de docência universitária, com a finalidade de preservarmos sua identidade.

\section{REFERÊNCIAS}

BARDIN, L. Análise do discurso. Lisboa. Edições 70, 1979.

BARCO de SURGUI, Suzana. Formação do docente universitário: mas quem é ele? In: VEIGA, Ilma Passos; CUNHA, Maria Isabel da (Org.). Desmistificando a profissionalização do magistério. Campinas, Papirus, 1999.

BARNETT, Ronald (ed.) Para una transformación de la universidad. Nuevas relaciones entre investigación, saber y docencia. Barcelona, Editorial Octaedro, 2008.

CUNHA, Maria Isabel da. O professor universitário na transição dos paradigmas. Araraquara/SP, JM Editora, 1998.

CUNHA, Maria Isabel da. O bom professor e sua prática. 15. ed. Campinas, SP: Papirus, 2003.

CUNHA, Maria Isabel da (Org). Formatos avaliativos e concepção de docência. Campinas, SP: Autores Associados, 2005.

Pedagogia Universitária: energias emancipatórias em tempos neoliberais. Araraquara, SP: Junqueira \& Marin, 2006.

. Qualidade do ensino de graduação: relação entre pesquisa, ensino e desenvolvimento profissional docente. Projeto de pesquisa, 2010.

MARCELO GARCIA, Carlos. Formação de professores. Para uma mudança educativa. Porto, Porto Editora, 1999.

PIMENTA, Selma (Org). Saberes pedagógicos e atividade docente. São Paulo: Cortez, 1999.

PIMENTA, S.; ANASTASIOU, Léa das Graças C. Docência no Ensino Superior. 3 ed. São Paulo: Cortez, 2008. 
MAYOR RUIZ, Cristina. Los condiciones profesionales del profesorado universitario. Um estúdio com profesores principiantes y com experiência. Revista Granada, v. 8, p. 27-51, 2001.

MAYOR RUIZ, Cristina. El desafio de los profesores principiantes universitarios ante su formación. In: MARCELO GARCIA, Carlos. El profesorado principiante: inserción a la docencia. Barcelona, Octaedro, 2009. p. 177- 210.

SANTOS, Boaventura de S. A universidade no século XXI: para uma reforma democrática e emancipatória da universidade. São Paulo: Cortez, 2004.

ZABALZA, Miguel A. O ensino universitário: seu cenário e seus protagonistas. Porto Alegre: Artmed, 2004.

Beatriz Maria Boéssio Atrib Zanchet é Doutora em Educação e professora do PPGE da UFPel. Orienta alunos doutorandos, mestrandos e bolsistas de iniciação científica. Os estudos e pesquisas têm como foco o ensino superior e a formação de professores, bem como seus saberes e práticas. 


\title{
DILEMAS CONTEMPORÂNEOS NA GRADUAÇÃO BRASILEIRA: DIRETRIZES CURRICULARES NACIONAIS (DCN), UM ESTUDO SOBRE O DOCUMENTO*
}

\author{
Jonathan de Oliveira Molar
}

\begin{abstract}
RESUMO: O presente artigo tem por objetivo analisar um documento oficial do sistema educacional brasileiro, as Diretrizes Curriculares Nacionais (DCN), apresentando como escopo de investigação a elaboração de um paralelo entre as Diretrizes e o contexto contemporâneo do mundo neoliberal/globalizado, a partir da leitura do corpo de texto do documento. Isto é, averiguar os dilemas, as contradições e convergências entre as Diretrizes (criadas para nortear o sistema educacional da graduação brasileira) e os pressupostos políticos, econômicos, educacionais e culturais do modelo neoliberal de sociedade. Para tanto, apoia-se nesse texto em noções capitais para o empreendimento de tal análise, tais como globalização, ideologia, currículo, poder etc.

Palavras-chave: Currículo. Neoliberalismo. Educação. Sociedade.
\end{abstract}

\section{INTRODUÇÃO}

O presente texto ${ }^{1}$ visa estabelecer um diálogo entre o contexto contemporâneo do mundo globalizado/ neoliberal associando-o ao campo educacional e explicitando os pontos de intersecção e/ou de combate entre as citadas áreas. Para tanto, utiliza-se como objeto de análise as "Diretrizes Curriculares Nacionais" (DCN) - documento oficial educacional em âmbito federal.

As DCN apresentam uma Diretriz Geral e outra Particular (específica) - destinada a cada curso de graduação; destarte, nesse artigo, analisa-se a Diretriz Curricular Geral, ou seja, aquela que serve de diretriz para todos os cursos de graduação do país, cuja abordagem são de temáticas macro

\footnotetext{
* Artigo recebido em 18/08/2011 e aprovado em 07/10/2011.
} 
e estruturais dos cursos. E, a título de investigação micro, faz-se uma breve discussão sobre a Diretriz Curricular Nacional do Curso de História e sua inserção na grade curricular da Licenciatura em História da Universidade Estadual de Ponta Grossa (UEPG), por meio de entrevistas com acadêmicos.

Historicamente, a Lei de Diretrizes e Bases (LDB) n. 5540/61, em seu artigo 26, atribuía ao extinto Conselho Federal de Educação o ato de definir e criar os chamados Currículos Mínimos dos cursos de graduação (documento anterior às DCN), vigentes desde as décadas de 1960 e 1970 no Brasil. Contudo, a Lei n. 9.131/95 modificou o panorama da área educacional, pois passava a atribuir à Câmara de Educação Superior do Conselho Nacional de Educação (CNE) a tarefa de elaborar as Diretrizes Curriculares Nacionais que orientariam os cursos de graduação. De acordo com a Lei 9.131/95, uma das atribuições da Câmara de Educação Superior é "c- deliberar sobre as diretrizes curriculares propostas pelo Ministério da Educação e do Desporto, para os cursos de Graduação" (BRASIL,1997, p. 1).

Desse modo, a Secretaria de Educação Superior (SESu) e o CNE elaboraram processos para nortear um ciclo de discussões sobre as linhas que deveriam ser implementadas nessa nova diretriz educacional, conforme estipula o Parecer CES/CNE, n. 776/97, e convocaram as Instituições de Ensino Superior (IES) a apresentarem suas propostas que, posteriormente, foram sistematizadas pelas Comissões de Especialistas de cada área do conhecimento. Para Bonamino e Martinez (2002, p. 371), "no plano políticoinstitucional ou estatal, a criação do Conselho Nacional de Educação (CNE) pela Lei n. 9131/95 procurou caracterizá-lo como um órgão representativo da sociedade brasileira".

Para a formulação das DCN, encaminharam-se, aproximadamente, 1.200 propostas - de universidades até organizações discentes. Em dezembro de 1998, as primeiras sugestões foram sistematizadas e disponibilizadas via endereço digital, após a formulação de uma primeira versão dos documentos pelos especialistas das diversas áreas.

A Diretriz Curricular teria por finalidade, teoricamente, guiar a elaboração dos currículos dos cursos de graduação, os quais deveriam se nortear nesse documento de âmbito federal, sancionado pelo ente estatal. Para a compreensão dessa intricada questão, o presente artigo aborda importantes noções como globalização, neoliberalismo, pós-modernidade e ideologia. Nesse sentido, pretende-se trabalhar com as Diretrizes Curriculares Nacionais e sua relação com a sociedade e o sistema neoliberal ante o campo educacional.

Enfim, essa pesquisa vale-se das seguintes indagações: quais são os fatores/hipóteses ao se atrelar a arena político-econômica neoliberal à educação? De que forma o currículo é posto para a sociedade? Suas 
imbricações epistemológicas estão norteadas por quais conjuntos de ideias e valores?

\section{IDEOLOGIA E A SOCIEDADE}

Os indivíduos tendem a utilizar uma série de símbolos, representações e ritos para expressarem suas posições no sistema sociocultural, justificando assim, suas atitudes e a constituição de uma realidade que o cerca e a interconexão com a comunidade. Dessa forma, os documentos oficiais da área educacional estão envoltos por concepções e práticas ideológicas, os quais fornecem suporte para a sua aplicabilidade nas escolas, universidades e, mais amplamente, na sociedade como um todo. Para Xavier,

as ideias e visões de mundo dos indivíduos fundamentam suas práticas, determinam quais os papéis legítimos e quais os estigmatizados [...] fundamentam práticas que tais elementos estão sujeitos a entrar no campo ideológico [...] são as práticas dos sujeitos, inseridas numa relação social, que reproduzem ou transformam os sistemas sociais e, portanto, mantêm ou superam as relações de poder e o status quo das classes sociais. (XAVIER, 2002, p. 33)

As ideologias, em geral, são revestidas por particularidades que possibilitam desenvolver funções de integração ou deformação. Isto é, na era das imagens, do neoliberalismo e da mundialização, a ideologia apresenta um alcance mais amplo e variado por meio dos meios de comunicação, partidos políticos, sistema educacional etc.

Atenta-se que as ideologias não são um retrato da realidade, porém, um modelo derivado de representações da realidade. Desse modo, não podem ser absolutas e/ou universais, mas sim, uma estrutura de conhecimento através do qual a sociedade é percebida, compreendida e interpretada. Conforme Wolkmer, "a criação e a fé em ideologias permitem não só justificar uma realidade que cerca o homem, mas também possibilitam desenvolver uma inter-relação mais direta e dinâmica entre os homens e a comunidade" (WOLKMER, 1995, p. 28).

O aspecto sociológico/político das ideologias faz com que se crie um vínculo entre o papel de constituição das identidades e dos sujeitos. As ideias e visões dos indivíduos fundamentam, legitimam suas práticas. A noção de poder associada à ideologia são reprodutores ou transformadores de ordens sociais, na segunda possibilidade, superando o status quo. Nesse sentido, a linguagem, melhor dizendo, o discurso não é usado somente para veicular informações, pois sua função denotativa é apenas uma dentre várias 
possibilidades. De acordo com Gnerre, "as pessoas falam para serem 'ouvidas', às vezes para serem respeitadas e também para exercer uma influência no ambiente em que realizam os atos linguísticos. O poder da palavra é o poder de mobilizar [...]" (GNERRE, 1991, p. 5).

"O poder da palavra é o poder de mobilizar", assim, indaga-se: quais os aspectos mobilizatórios e ideológicos - objetivos ou ocultos - que estão presentes nas Diretrizes Curriculares Nacionais? Ou, então, de que forma o discurso elaborado por especialistas da área, as modificações e interposições da CNE e da sociedade em geral ressoam no citado documento e, mais amplamente, na educação? Mais à frente, a pesquisa fornecerá indícios e interpretações de algumas dessas indagações.

Ao se produzir uma ordem discursiva apoia-se em uma busca pela verdade, o conteúdo ali proferido aspira a tornar-se legítimo, incontestável em dada realidade. É, ao mesmo tempo, reforçado por todo um conjunto de práticas e de saberes, dando suporte a sua pretensa validade. Para Konder,"na linguagem reconhecemos a realidade constituída, mas nos defrontamos ao mesmo tempo com a realidade que ainda não foi criada e que nós mesmos estamos inventando" (KONDER, 2002, p. 192).

Assim, os discursos, os grupos que os proferem e os divulgam socialmente ligam-se uns aos outros e constituem um grande edifício que garante a distribuição dos indivíduos que são porta-vozes nas diversas espécies dos discursos, envolvidos por uma qualificação de papéis - não sendo diferente no campo educacional, tanto em espaços micro quanto macro.

\section{GLOBALIZAÇÃO, NEOLIBERALISMO E PÓS-MODERNIDADE}

A chegada da pós-modernidade ou a renovação da própria modernidade liga-se ao surgimento de uma sociedade industrial neoliberal a partir do último quartel do século XX, cujas formas de conhecimento tornam-se a força motriz de produção, sendo ressignificadas pelas transformações que o capitalismo necessita para oxigenar suas bases e perpetuar suas diretrizes.

Conforme Sanfelice (2003), o termo pós-modernidade surge no mundo das artes para, posteriormente, ser abordado pelo filósofo J. F. Lyotard no início da década de 1980. Não cabe, na presente pesquisa, discutir teoricamente a qual corrente teórica (modernidade ou pós-modernidade) encontra-se a sociedade do século XXI; contudo, parte-se do entendimento de que os defensores do sistema capitalista/neoliberal, ao rechaçarem os mitos justificadores da modernidade, por exemplo, o ideal iluminista (universal e humanizante) pretendem defender, com isso, novas formas de introjeções 
discursivas e sociais sobre a noção de modernidade na contemporaneidade, decorrentes das próprias transformações pelas quais as sociedades passam.

Aprofundando a consideração, a pós-modernidade é uma nova roupagem para o mesmo espírito moderno, um jogo no qual se criam inovações, porém, mantendo permanências. Cunhar novos termos é o mecanismo de sobrevivência do capitalismo e a modernidade que se originou sob tal denominação em fins do século XVIII (SANFELICE, 2003) acaba por ser aposentada, ao menos, em vias conceituais.

Durante os anos 80, o mundo passou por uma série de transformações com a euforia do capitalismo soberano e o gradual colapso do bloco soviético. Ocorre, desde então, o domínio de uma grande narrativa - a do neoliberalismo globalizado. Segundo enfatiza Chomsky, o neoliberalismo é o paradigma econômico e político que define nosso tempo. Consiste em um conjunto de práticas políticas e processos que permitem a um número relativamente pequeno de interesses particulares controlar a maior parte possível da vida social com o objetivo de maximizar seus benefícios individuais (CHOMSKY, 2002, p. 7).

Inicialmente associado ao ex-presidente norte-americano Reagan e à ex-primeira ministra inglesa Thatcher, o neoliberalismo tornou-se a principal tendência econômico-política dos partidos políticos de direita e de centro e, até mesmo, de esquerda em algumas nações; as iniciativas neoliberais caracterizam-se pelo livre mercado que incentiva o empreendimento privado e a escolha do consumidor, ao passo que freia a participação da máquina estatal. Conforme Chomsky", em vez de cidadãos, ela produz consumidores. Em vez de comunidades, produz shopping centers. O que sobra é uma sociedade atomizada, de pessoas sem compromisso, desmoralizadas e socialmente impotentes" (p. 12).

As diretrizes da modernidade, a partir do viés interpretativo neoliberal, afetaram também as experiências e visões de mundo dos indivíduos, pois entre os traços dessa "nova subjetividade" está a perda do senso ativo da História. O sujeito pós-moderno (moderno) é marcado por polaridades, encontra-se entre a corrida materialista e o vazio subjetivo de noções hoje distantes como a ética e a cidadania. Para Hall,

quanto mais a vida social se torna medrada pelo mercado global de estilos, lugares e imagens, pelas viagens internacionais, pelas imagens da mídia e pelos sistemas de comunicação globalmente interligados, mais as identidades se tornam desvinculadas - desalojadas - de tempos, lugares, histórias e tradições específicos e parecem 'flutuar livremente'. (HALL, 1999, p. 75) 
De acordo com Sanfelice, "pós-modernidade, para nós, portanto, é um fenômeno, dentre outras coisas, que expressa uma cultura da globalização e da ideologia neoliberal" (SANFELICE, 2003, p. 7). Os modos de vida produzidos pela globalização, durante o século XX, desvencilharam-na dos tipos tradicionais das ordens precedentes, tanto em extensão quanto em intensificação; sobre a primeira, estabelece formas de interconexão que cobrem o globo, quanto à segunda, altera algumas características de foro privado dos sujeitos. Para Giddens,

o dinamismo na modernidade [nessa pesquisa concebida como pós-modernidade] deriva da separação do tempo e do espaço [...] do desencaixe dos sistemas sociais; e da ordenação e reordenação reflexiva das relações sociais à luz das contínuas entradas (inputs) de conhecimento afetando as ações de indivíduos e grupos. (GIDDENS, 1991, p. 25)

As culturas que precederam o século XX possuíam maneiras de calcular o tempo, as quais constituíam a base da vida cotidiana, vinculando tempo e lugar, conforme os tradicionais relatos de Dickens e Baudelaire, respectivamente, da Inglaterra e França do século XIX. A globalização dinamizou a relação espaço-temporal, imprimindo a aceleração de processos globais - com distâncias mais curtas, os eventos que ocorrem em determinado local têm o impacto refletido sobre demais pessoas e lugares situados a uma grande distância (HALL, 1999).

O sujeito líquido (BAUMAN, 2005) apresenta identidades cambiantes inseridas nesse espaço e tempo simbólicos e, ao mesmo tempo em que se identifica, fragmenta-se. Produz-se uma diluição de códigos culturais, com ênfase no efêmero, na diferença e no pluralismo identitário. Contudo, as distinções culturais que antes definiam as identidades ficam reduzidas a uma "língua franca internacional ou moeda global" (HALL, 1999, p. 75), nas quais podem ser codificadas.

Dessa forma, a globalização e a pós-modernidade (modernidade) adquirem uma configuração histórico-social em que os indivíduos se movimentam em realidades sociais, econômicas, culturais e políticas que emergem e dinamizam-se nessa sociedade global. O que não significa, entretanto, que seja o fim da História ou seu último sistema sócio-político; nota-se a sustentação de uma realidade impositiva, a qual poderá vir a ser sucedida ou não, transformada ou ressignificada.

\section{EDUCAÇÃO, CURRÍCULO E PODER}

O apelo por reformas educacionais apresenta-se, atualmente, aos professores e demais profissionais da área de ensino tanto como uma ameaça 
quanto um desafio. A realidade cotidiana que reduz ao status de técnicos os docentes, além de os objetivos educacionais estarem direcionados por especialistas afastados do ambiente escolar, mostra-se "soberana" na educação, entretanto, focos transformadores nascem na sociedade, em especial, da década de 1990 para cá (SANFELICE, 2003).

Por mais que o campo não esteja favorável para professores críticos e o clima político-ideológico mostre-se sob as rédeas do neoliberalismo e da pós-modernidade, oferece-lhes o desafio de unirem-se ao debate público e de se engajarem em uma autocrítica franca sobre a preparação de docentes, meios de escolarização, introdução dos currículos etc. Desse modo, o desafio a ser lançado consiste no debate e na proposição de alternativas para a crescente falta de escolhas e de autonomia dos professores, mas também, em desvelar a crise e o descrédito da população sobre qual o papel que ela espera dos docentes. Conforme Apple (1989, p. 20),

a crise, embora claramente relacionada a processos de acumulação de capital, não é somente econômica. Ela é também política e cultural/ideológica. Na verdade, é na intersecção dessas três esferas da vida social, na forma como elas interagem, na forma como cada uma delas sustenta e contradiz as outras, que podemos vê-la em sua plena forma.

As racionalidades técnico-burocráticas operam com intensidade no campo da educação a partir das premissas neoliberais de formação de indivíduos como mão de obra para o mercado de trabalho em diversos níveis, afastando assim, a noção de cidadania participativa. Conforme Giroux, essa realidade denomina-se "pacotes curriculares à prova de professores", reservando aos docentes o simples papel de executores de conteúdos previamente escolhidos por especialistas, muitas vezes, pouco associados à área da educação. $\mathrm{O}$ autor ainda destaca:

O método e objetivo de tais pacotes é legitimar o que chamo de pedagogias de gerenciamento. Isto é, o conhecimento é subdividido em partes diferentes, padronizado para ser mais facilmente gerenciados e consumidos, e medidos através de formas de avaliação predeterminadas. As abordagens curriculares deste tipo são pedagogias de gerenciamento porque as principais questões referentes à aprendizagem são reduzidas ao problema da administração, isto é, como alocar recursos para produzir o número máximo de estudantes. (GIROUX, 1997, p. 160)

A partir das premissas citadas por teóricos, como Giroux, Apple e Mclaren, deve-se argumentar a favor da necessidade de repensar a natureza e a posição do docente não só em âmbito escolar, mas na sociedade compreendendo-o como intelectual crítico. Dessa forma, preconiza-se um 
agente que reflete sobre o campo educacional e o contexto no qual está inserido, propondo alternativas e possibilidades de transformá-lo, analisando também as condições ideológicas, os focos de poder presentes na sociedade e na escola e de que modo mediá-las (GIROUX, 1997).

Nesse sentido, o currículo é compreendido como um discurso que engendra atos e teorias político-econômicas na esfera pedagógica, ao passo que constitui um centro de disputas em torno de quais princípios políticos, morais, entre outros, devem ser perpetuados e repassados como fundamentais no processo de aprendizagem. Enfim, a discussão sobre os professores enquanto intelectuais perpassa todo o campo educacional, desde a implementação das políticas públicas para a área à prática de ensino em sala de aula (MCLAREN, 1997).

\section{A Diretriz Curricular Geral: contrapontos e reflexões}

A partir das discussões já empreendidas sobre a contemporaneidade e alguns de seus âmbitos, tais como: o cultural, o político e o educacional, pode-se adensar a análise sobre as Diretrizes Curriculares Nacionais. Nesse caso, tendo como objeto de investigação a Diretriz Geral voltada como ponto norteador para a elaboração dos currículos de todos os cursos de graduação.

Durante o processo de implementação da Diretriz Curricular Geral, foram apontados pelos docentes e discentes participantes os principais problemas dos Currículos Mínimos, os quais alicerçavam a Educação Superior brasileira na década de 1960. As críticas consistiam em:

Detalhamento de disciplinas e de cargas horárias prefixadas dificultando a implementação de projetos pedagógicos atualizados e voltados às demandas sociais;

Estrutura estática do currículo mínimo determinando uma formação, na qual não há espaço para as mudanças e as adaptações necessárias ao acompanhamento das transformações que ocorrem nas diferentes áreas de conhecimento;

Defasagem entre teoria e prática (o aluno passa a ter contato tardiamente com a realidade de sua área, o que contribui de modo significativo para os elevados índices de evasão e a falta de percepção adequada de sua vocação); As licenciaturas apresentam-se como apêndices à visão tradicional dos bacharelados, sem o aprofundamento de suas especificidades;

Necessidade de melhor contextualizar o perfil do diplomado frente às demandas e transformação das profissões. (BRASIL, 1997, p. 5)

Neste excerto, os termos que se destacam são cargas horárias prefixadas, estrutura estática do currículo, defasagem entre teoria e prática e 
as licenciaturas enquanto apêndices dos bacharelados; assim, representa-se no discurso das DCN o atraso para a área educacional brasileira dos Currículos Mínimos. Desse modo, pode-se indagar: as Diretrizes Curriculares vêm conseguindo dar conta dessas mudanças? A partir de quais princípios? Sob qual prisma? Apresentam-se abaixo possíveis caminhos para tais respostas.

O corpo do texto da Diretriz Geral aponta para os Currículos Mínimos como normas gerais válidas para as IES de todo o território nacional, de tal maneira que os acadêmicos eram contemplados uniformemente nos conteúdos, na duração e denominação dos cursos (diferenciando-se, apenas, em relação às disciplinas complementares e optativas). Assim, tais características favoreciam as transferências de discentes entre as diversas Instituições Superiores, sem a necessidade de integralização curricular. A duração dos cursos, de forma determinada, fixava o tempo em mínimo, médio e máximo, implicando elevado detalhamento de disciplinas e cargas horárias (BRASIL, 2003). De acordo com o texto das atuais Diretrizes:

Dado esse caráter universal dos currículos mínimos para todas as instituições, constituem-se eles numa exigência para uma suposta igualdade entre os profissionais de diferentes instituições, quando obtivessem os seus respectivos diplomas, com direito de exercer a profissão, por isto que se caracterizavam pela rigidez na sua configuração formal, verdadeira 'grade curricular', dentro da qual os alunos deveriam estar aprisionados, submetidos [...] (BRASIL, 2003, p. 2)

A noção de igualdade atribuída aos Currículos Mínimos diz respeito a uma homogeneização de carreiras e disciplinas que se opõe ao princípio da Isonomia da Constituição Federal do Brasil, o qual supõe tratar os iguais na medida em que se igualam e os desiguais na medida em que se desigualam. Dessa forma, as DCN se propuseram a abordar a diversidade dentro da esfera da igualdade e no reconhecimento da pluralidade como um fator primordial.

Observa-se que os Currículos Mínimos foram considerados pelas atuais DCN como "carcereiros" do sistema da graduação, argumentando-se que rigidamente concebidos não mais permitiam alcançar a qualidade desejada e imposta pelo tempo/espaço, já que, epistemologicamente, foram superados já na década de 1970, pois inibiam a inovação e a diversificação na formação do profissional voltado à adaptabilidade, entenda-se - mercado de trabalho.

Com o advento da Lei n. 9.131/95 que conferiu ao CNE a competência para gerir e deliberar um novo documento - de cunho "moderno e adaptável" - para os cursos de graduação é que nasce o Parecer 776/97 com o propósito de orientar as Diretrizes Curriculares. Segundo este Parecer, as Diretrizes deveriam seguir estes princípios: 
1) Assegurar às instituições de ensino superior ampla liberdade na composição da carga horária a ser cumprida para a integralização dos currículos, assim como na especificação das unidades de estudos a serem ministradas;

2) Indicar os tópicos ou campos de estudo e demais experiências de ensino-aprendizagem que comporão os currículos, evitando ao máximo a fixação de conteúdos específicos [...]

3) Evitar o prolongamento desnecessário da duração dos cursos de graduação;

4) Incentivar uma sólida formação geral, necessária para que o futuro graduado possa vir a superar os desafios de renovadas condições de exercício profissional e de produção do conhecimento [...]

5) Estimular práticas de estudo independente, visando a uma progressiva autonomia profissional e intelectual do aluno;

6) Encorajar o reconhecimento de conhecimentos, habilidades e competências adquiridas fora do ambiente escolar [...]

7) Fortalecer a articulação da teoria com a prática [...]

8) Incluir orientações para a condução de avaliações periódicas [...] (BRASIL, 1997, p. 3)

De acordo com os itens acima, assegurar liberdade na composição de carga horária, evitar o prolongamento na duração dos cursos de graduação, incentivar formação geral e estimular práticas de estudos independentes correspondem ao ideal de liberdade preconizado pelo sistema neoliberal, ou seja, um amplo espaço para a individualização dos sujeitos, com um Estado de intervenção mínima - tanto na arena político-econômica quanto educacional. Segundo Ortiz, "a [pós] modernidade se associa à racionalização da sociedade, em seus diversos níveis, econômico, político e cultural [...] privilegiando qualidades com funcionalidade, mobilidade e racionalidade" (ORTIZ, 1996, p. 50).

Evidencia-se, assim, um modelo (roteiro) de enquadramento das Diretrizes Curriculares, no qual se propõe uma lógica a ser seguida, inserindose as especificidades e a flexibilização de cada curso. Nesse sentido, as DCN constituem-se como referência centralizada para as Instituições Superiores na elaboração de seus currículos, isto é, "[...] permitindo flexibilidade e priorização de áreas de conhecimento na construção dos currículos plenos" (BRASIL, 2003, p. 4).

Ora, nesse entender, a flexibilização gera a fragmentação das áreas de conhecimento e de seus respectivos profissionais, sendo que a priorização dessas áreas dá-se entre o jogo de oportunidades e campos considerados essenciais/ privilegiados dentro do sistema neoliberal. Logo, surge o questionamento: seriam as Diretrizes tão distintas dos Currículos Mínimos? 
Nesse sentido, conforme o Parecer 776/97, as Diretrizes deveriam contemplar:

A - Perfil do formando/egresso/profissional [...]

B - Competência/habilidades/atitudes

C - Habilitações e ênfase

D - Conteúdo Curricular

E - Organização do curso

F - Estágios e atividades complementares

G - Acompanhamento e avaliação. (BRASIL, 1997, p. 5)

Com isso, reluz nitidamente que a Diretriz Geral vista como "flexível" pretende controlar, por meio das questões macro, o sistema educacional como um todo, pois instaura referências desde as habilidades esperadas até o acompanhamento das disciplinas e da avaliação. Os discursos presentes nos pareceres que antecedem as atuais Diretrizes configuram-nas, então, como panaceia de todos os males, "vendendo" ideias a partir da contraposição ao modelo dos Currículos Mínimos, considerado rígido e ultrapassado. Habilidosamente, alguns termos são reduzidos e abarcados como noções da alta moda como - autonomia, ética, criatividade etc. De acordo com Foucault,

as interdições que o atingem [o discurso] revelam logo, rapidamente, sua ligação com o desejo e com o poder. [...] o discurso não é simplesmente aquilo que traduz as lutas ou os sistemas de dominação, mas aquilo por que, pelo que se luta, o poder do qual nós queremos apoderar. (FOUCAULT, 2006, p. 10)

De fato, o modelo do Currículo Mínimo não daria mais conta da complexificação social da contemporaneidade, necessariamente, também, não suportaria as mudanças pelas quais a sociedade brasileira passou em quase três décadas. Contudo, as Diretrizes criticam-no incisivamente, sem abordar explicitamente a que veio e quais objetivos pretendem assegurar. Nesse sentido, seu discurso oculta sob temáticas da diversidade um espaço de poder agregado ao ensino e atrelado à política e à economia.

O texto da Diretriz Geral carrega em seu bojo uma visão de mundo, em grande parte, de grupos dirigentes alinhados ao sistema macroeconômico neoliberal que, por meio dos documentos educacionais elaborados via CNE, pretendem inserir o sistema educacional nesse processo global. As transformações no mundo do trabalho apresentam uma conjuntura complexa e contraditória, sendo que a problemática do conhecimento e da formação profissional associada à reestruturação produtiva reflete-se na escola. Com 
isso, as reformas educacionais brasileiras têm-se concentrado nesse caminho, propondo modificações desde a educação básica à graduação.

Percebe-se que o ideário de reformar o campo educacional está, em especial, agregado à abertura e à participação do país ao mercado externo (fator esse bem conhecido dos países americanos que possuem um passado colonial). Nessa linha, durante o governo do ex-presidente Fernando Henrique Cardoso (1994-2002), assistiu-se à abertura econômica e à reforma da legislação trabalhista objetivando a flexibilização de cursos e profissionais (CATANI; OLIVEIRA; DOURADO, 2001).

As privatizações em áreas energéticas, elétricas etc. também se expandiram no campo educacional com o crescimento de Instituições Privadas e o desmantelamento das Instituições Públicas - em que o baixo salário de professores, a falta de profissionais para o início do ano letivo e a perda de mobilização da classe docente perante o Estado - são apenas alguns desses sintomas.

Com o Parecer 67/2003 do CNE, tornou-se notória a orientação de voltar-se para a flexibilização. Conforme o documento, "ficou evidente que, ao aprovar as Diretrizes Curriculares Nacionais para os Cursos de Graduação, a intenção é mesmo garantir a flexibilização, a criatividade e a responsabilidade das instituições de ensino superior" (BRASIL, 2003, p. 5). Nessa linha, no mesmo Parecer, explicita-se:

As Diretrizes [...] orientam-se na direção de uma sólida formação básica, preparando o futuro graduado para enfrentar os desafios das rápidas transformações da sociedade, do mercado de trabalho e das condições de exercício profissional [...] visando a uma progressiva autonomia profissional e intelectual do aluno, apto a superar os desafios de renovadas condições de exercício profissional e de produção de conhecimento e de domínio de tecnologias. (p. 6)

Preparar o futuro graduado para enfrentar os desafios das rápidas transformações da sociedade, do mercado de trabalho e das condições de exercício profissional corresponde ao processo de inserção ou adaptação de sistemas de conhecimentos à fugacidade e à concorrência, ambas emersas em uma estrutura de intervenção mínima. Segundo Foucault, "todo sistema de educação é uma maneira política de manter ou de modificar a apropriação dos discursos, com os saberes e os poderes que eles trazem consigo" (FOUCAULT, 2006, p. 44).

A flexibilidade dos processos de trabalho, mercados e produtos tornam-se etapas imperiosas para o sistema capitalista. Assim, as Diretrizes, ao explicitarem "o perfil de um formando adaptável às novas e emergentes 
demandas" ou para "enfrentar os mercados de trabalho", agregam a inserção desse formando no processo de acumulação flexível. Ora, o documento cita termos como mercado de trabalho e transformações da sociedade, contudo, não se visualiza no texto das DCN sobre qual sistema essas variantes operam, ocultando assim as noções e intenções neoliberais.

Ademais, o processo de flexibilização gera, como consequência, o desemprego estrutural. A exceção encontra-se justamente no setor do conhecimento, quer dizer, dos profissionais que lidam com a informação, os quais se apresentam no centro gravitacional desse processo. Dessa forma, não é difícil supor por que tanta atenção é dada às reformas educacionais pelas esferas Federal, Estadual e Municipal.

O Parecer 67/2003, ao expressar que "as Diretrizes Curriculares Nacionais devem ensejar variados tipos de formação e habilitações diferenciadas em um mesmo programa" (BRASIL, 2003, p. 6), reflete as implicações do viés empresarial, o entendimento de que os novos perfis profissionais e os modelos de formação exigem polivalência e flexibilidade. Segundo Catani, Oliveira e Dourado (2001),

o desenvolvimento dessa polivalência e flexibilidade profissional incluiria a identificação de habilidades cognitivas e de competências sociais requeridas no exercício de diferentes profissões, bem como nos diferentes ramos de atividade. (p. 6)

Nesse sentido, flexibilizar também significa ajustar e aligeirar a formação acadêmica. O Parecer 67/2003 elenca o artigo 22 da Constituição Federal, no qual as instituições (entendidas de modo geral) devem assumir a ousadia, criatividade e inventabilidade. Essas três noções aparecem no texto do Parecer associadas à flexibilização, visando a justificá-la. Assim, criatividade corresponde (para os especialistas que elaboraram as Diretrizes) à crise e ao desemprego global?

De fato, o documento explicita a necessidade de adaptação às mudanças sociais, políticas etc., porém, quais são essas mudanças e suas consequências? No discurso das Diretrizes, não há referência ao desemprego e à desestruturação; as exigências do meio neoliberal proclamam sacrifícios, cujos sintomas negativos não são enunciados.

Na Diretriz, com base no artigo 205 da Constituição Federal, incentivase o ideal de colaboração entre as instituições da sociedade, destarte, como se pode colaborar com um conjunto de reformas obscuras e de resultados que parecem óbvios, em sua maioria, negativos?

Em síntese, a flexibilização curricular está intimamente associada à reestruturação produtiva do neoliberalismo; assim, a formação de profis- 
sionais polivalentes e adaptáveis às transformações do mundo do trabalho correspondem aos problemas de desemprego e de abertura econômica à globalização.

5.1 A Diretriz Curricular Nacional do Curso de História: um olhar sobre a Licenciatura em História da Universidade Estadual de Ponta Grossa (UEPG)

Nesse momento, a discussão, a partir de considerações micro (com base em entrevistas a acadêmicos da Licenciatura em História da UEPG) e na análise dos documentos oficiais (A Diretriz Nacional do curso de História e o Projeto Pedagógico da Licenciatura em História da UEPG) torna possível evidenciar questões macro, muitas delas, críticas e geradoras de conflitos sobre o currículo e de noções acessórias: ética, neoliberalismo etc.

Foram entrevistados quatro acadêmicos da Licenciatura em História da UEPG, ${ }^{2}$ cujas perguntas pretendiam expor e analisar a inserção dos currículos no curso de História, as dificuldades e os dilemas encontrados na sua formação visto que serão futuros professores. Desse modo, pretende-se dialogar com a teoria e a prática de ensino, o que esclarece as discussões do tópico anterior.

As Diretrizes Curriculares de História iniciam seu discurso realizando uma contextualização entre pesquisa e ensino na referida área. Expõe-se que os antigos Currículos Mínimos, da década de 1960, apresentavam para a graduação em História baixo grau de profissionalização e limitada atividade de pesquisa para docentes e discentes.

Desse modo, as Diretrizes Curriculares trariam maiores possibilidades para o profissional lidar com a pesquisa, além do estreitamento da relação entre Bacharelado e Licenciatura em História, pois a atuação dos historiadores dá-se, por exemplo, em escolas, universidades, museus, arquivos, meios de comunicação (BRASIL, 2001).

O PPC do curso de História da UEPG também elabora um discurso que, apesar das distinções elencadas entre as formações do licenciado e do bacharel, ${ }^{3}$ apoia uma complementaridade entre as áreas. Segundo o documento,

embora a licenciatura e o bacharelado formem para habilitações distintas, a formação em cada uma dessas opções será a mais assemelhada possível, dentro do argumento da não dicotomização das formações, respeitadas, valorizadas, enfatizadas e priorizadas plenamente todas as especificidades da formação do professor e na perspectiva de sua valorização, de acordo com as diretrizes curriculares para o ensino de História. (UNIVERSIDADE ESTADUAL DE PONTA GROSSA, 2005, p. 10) 
De fato, até pouco tempo atrás, prevaleciam os cursos de Licenciatura em História, embora seus currículos apresentassem características de Bacharelado, tanto que a implementação do Bacharelado, em algumas universidades, torna-se fato recente e incipiente; diga-se de passagem, implementação essa, institucional, afinal, já havia a estrutura curricular do Bacharelado atuando na Licenciatura. Contudo, a separação entre Bacharelado/Licenciatura advém das próprias imposições do neoliberalismo (CHOMSKY, 2002); inverte-se a ordem e dá-se maior destaque ao Bacharelado em razão de sua proximidade com a pesquisa e a abrangência de áreas de inserção socioeconômicas.

Dessa forma, essa afirmação da Diretriz (pesquisa/ensino) e do PPC não está equivocada, todavia, indaga-se: de que maneira pretende-se conectar as duas atividades? Concentrando as duas em um profissional engajado e crítico ou naquele polivalente e amplo? O seguinte trecho das DCN fornece alguns indícios:

Se nos limitarmos exclusivamente ao que é específico, uma grande diferença existe, por exemplo, entre os programas de História que oferecem exclusivamente formação na Graduação e aqueles - em número muito minoritário ainda - que possuem a Pós-Graduação stricto sensu. (BRASIL, 2001, p. 7)

Essa segmentação entre Bacharelado e Licenciatura é necessária à formação do profissional "adaptado ao mercado de trabalho", em outros termos, é mais uma distinção obscura da mentalidade das universidades brasileiras regidas sob a batuta neoliberal, sendo recebida pelos acadêmicos de forma negativa: "Um lixo!" (H3), ${ }^{4}$ diz uma acadêmica, e ainda, "Uma porcaria!" (H4).

Na percepção dos acadêmicos, de maneira geral, na Licenciatura em História, não se forma nem um professor nem, muito menos, um pesquisador. Conforme a acadêmica, "nenhum dos dois profissionais sai preparado" (H3). Desse modo, não há uma ampla formação de pesquisadores e de professores.

Pesquisa e docência caminham juntas, essa dicotomia institucional proposta pelas DCN e pelo PPC do curso implodem a noção da História enquanto área do conhecimento crítica e integrada, voltada à alteridade. Vejamos a reflexão feita por uma acadêmica sobre o bacharelado e a licenciatura:

A licenciatura não tem a bagagem da pesquisa e o bacharelado apesar de ter duas Oficinas de Ensino [agora não tem mais] e mesmo que tivesse uma maior abrangência na questão da educação, mesmo assim, na prática nunca vai conseguir fazer nada com a educação; a licenciatura na pesquisa muito menos, a não ser que vá direto para um mestrado, doutorado. $(\mathrm{H} 3)$ 
Há, assim, uma rivalidade entre os acadêmicos. De acordo com um deles,

o pessoal do bacharelado tem aquela ideia de que eles adoram História, então se eles chegarem a uma sala de aula acham que vão passar o conteúdo bem certinho, eles não entendem que a História é uma ponte para atingir outros objetivos, não interessa se ele vai decorar dados ou o que aconteceu naquele momento histórico. Tem muito aluno do bacharelado que não entende isso, para que estudar como ensinar História, é tão obvio, tão estúpido e eles saem com essa visão de quem faz licenciatura. Acaba com os dois cursos se odiando, em uma viagem o pessoal do bacharelado chamava a gente de pedagogo. $(\mathrm{H} 1)$

Os acadêmicos da Licenciatura rejeitam a formação pedagógica. Ocorre, com isso, o isolamento entre os cursos, pautado por um viés diminuído e pejorativo, turvando o interesse dos acadêmicos pelas duas formações que, aliás, deveriam estar contempladas em um só currículo, com base em uma outra estruturação e organização.

O professor intelectual/crítico e com uma formação que contemple as duas áreas apresenta-se como uma visagem distante dos acadêmicos. Os primeiros esforços vêm sendo realizados, mas de modo incipiente. Para aqueles que pretendem alcançar tanto a formação do Bacharelado quanto a da Licenciatura, o caminho é longo; segundo um participante, "o acadêmico conhece História, gosta de História e nem sabe o porquê. Cabe ao acadêmico por conta própria complementar sua formação" (H1).

Nessa direção, o currículo da forma como que vem sendo colocado, novamente, recebeu uma série de críticas: "O currículo como está todo mundo reclama, uma realidade muito difícil" (H3). Em outra declaração:"Fica pesado em umas coisas que não precisavam e fica leve no que podia bater em cima" (H3).

Ressurgiu, posteriormente, ao centro das discussões, a relação universidade/colégio e, consequentemente, seus pontos de atrito. Segundo duas acadêmicas, "a gente chega na escola e tem que reaprender de volta" (H4), e "mesmo a escola não tem estrutura para isso, nem as escolas nem os professores que já estão há tempo formado, todo mundo sofre um dilema" (H3), isto é, o reaprender em meio a desafios e circundado pela frágil estrutura das escolas do país, local esse, cuja defasagem de professores e alunos, em alguns momentos, são visíveis:

- É pior ainda os que já estão formados há mais tempo porque aí nem pensar em universidade eles pensam. $(\mathrm{H} 3)$

- Na escola em que trabalho eu ajudo os alunos a fazer tarefas e trabalhos de História, assim aqui eles trabalham com aluno modelo, ele vai aprender tal 
coisa e depois tal coisa, você chega, hoje, por exemplo, ajudando um aluno a estudar para uma prova sobre Brasil Império e escrevia muito mal, muito mal. Levei mapa para a sala esses tempos e eles achavam que a Europa era um país. $(\mathrm{H} 4)$

As falas tendem a atestar que o professor não aborda o conteúdo apenas em sala de aula, mas também, acumula uma série de outras funções decorrentes das necessidades dos alunos; literalmente, fragmenta-se o docente em pedaços para tentar amenizar as deficiências em sala de aula. A noção de aluno "modelo" aliena e encobre ainda mais essa realidade, são poucos os professores na universidade que abordam a situação com criticidade. Uma acadêmica comentou que"a escola tentou fazer um currículo diferente, a cada mês a escola tinha que usar um dia, por exemplo: dia do Tiradentes, dia da merendeira, dia da faxineira, cada um fazia um desenho e tinha que entregar para elas. É algo pontuado demais" (H4).

De modo geral, visualizam-se algumas incongruências entre o cerne do pensamento que se objetiva alcançar (na teoria) e o que de fato está colado no discurso enquanto práxis. Intensificam-se, dessa forma, os esforços para distanciar o bacharel do licenciado, mesmo nas universidades em que os unem sob um mesmo currículo. Será que não há possibilidade de concretização de um pesquisador que lecione ou de um professor que pesquisa? A resposta parece clara, sim! Contudo, inviável para o atual modelo de gerenciamento da educação.

Infere-se um currículo distante dos anseios de acadêmicos e dos demais níveis de ensino, pois a timidez e a insegurança dos participantes revelam uma formação defasada, que resiste e avança em alguns momentos pela iniciativa de um grupo de professores e alunos. Sobre o currículo de História, Luís F. Cerri afirma:

As disciplinas de conteúdo obrigatório devem assumir uma linha necessariamente historiográfica, sendo entendido que o conhecimento factual, quando não garantido pelos estudos de nível médio, é responsabilidade extraclasse do acadêmico, com bibliografia sugerida e orientação geral fornecidas pelo professor; um princípio geral que decorre desta postura é que um currículo que se pretende formador de profissionais autônomos, críticos e criativos não pode ser paternalista a ponto de resolver deficiências em saberes que deveriam ser requisitos prévios para ingresso no ensino superior [...] mas sim pela orientação e por condições para que o aluno possa agir no sentido da superação de suas limitações. (CERRI, 2004, p. 38)

A prática decorrente do estágio e as experiências vividas registram as dificuldades e o local de crescimento desses futuros docentes, os quais 
avaliam com clareza os nós do currículo e as frustrações advindas deste; citar termos da "alta moda" nos currículos é uma questão linguística, já transformar a realidade com tais termos, demanda criticidade e autonomia.

\section{Considerações FinaIS}

A ótica do trabalho flexível e da globalização, engendradas pelo neoliberalismo, espraiaram suas ambições e o modus operandi para a área educacional - conforme enfatiza Chomsky, "o lucro superou as pessoas" (2002) - refletindo em propostas pretensamente democráticas e a favor da alteridade nos documentos oficiais, ao passo que os currículos foram elaborados, em quase sua totalidade, para privilegiar uma formação tecnicista e reducionista.

A fuga de noções como ética e cidadania, analisadas sob o fio condutor da alteridade e como exercício democrático e de intervenção social indicam um rumo distante do encontrado na Diretriz Curricular Geral. A criticidade do intelectual/professor, aclamada por Giroux (1997) e Mclaren (1997), longinquamente vem sendo agregada aos nossos futuros docentes. Cursos de graduação que não convergem para questões relativas à alteridade, realidade social e democrática do país; em certa medida, também os grupos que administram o sistema neoliberal deixam como recado aos futuros profissionais: "professores, repassem o conteúdo, quanto aos alunos, estes..."

Em síntese, a Diretriz Curricular torna-se um dentre tantos documentos educacionais formulados pelo Estado brasileiro, tendo a tendência neoliberal como geradora da base para currículos e linhas norteadoras do ensino, percorrendo do ensino básico à graduação. $\mathrm{E}$, com base nas afirmações encontradas nas obras de Mclaren e de outros autores, atenta-se para uma questão global, diria, um problema crônico global, o qual é sentido com maior intensidade nas chagas histórico-colonizatórias e no alijamento contemporâneo das nações da América Latina.

CONTEMPORARY DILEMMAS FOR BRAZILIAN UNDERGRADUATE COURSES: A STUDY OF THE NATIONAL CURRICULUM GUIDELINES

AвSTRACT: The aim of this paper is to examine the National Curriculum Guidelines, an official federal document on the Brazilian educational system. It does so by drawing a parallel between the Guidelines and the contemporary context of the neoliberal globalized world from a reading of the document. It analyzes the dilemmas, contradictions and convergences between the Guidelines (drawn up as an inspiration for the Brazilian undergraduate educational system) and the political, economic, educational and cultural presuppositions of the neoliberal model of society. So, this 
text is based on ideas which are vital for such an analysis, namely, globalization, ideology, curriculum, power etc.

KEYwords: Curriculum. Neoliberalism. Education. Society.

\section{NOTAS}

1. Esse artigo é um recorte temático da dissertação defendida no Mestrado em Educação da Universidade Estadual de Ponta Grossa (UEPG), cujo título é Faces da alteridade: dilemas e convergências entre documentos oficiais e a formação de professores na UEPG. Dissertação defendida em 17/12/2009.

2. A discussão sobre a Licenciatura em História da UEPG faz parte da dissertação defendida no Mestrado em Educação da UEPG. Para o presente momento, houve um recorte mais objetivo da discussão, atendendo, assim, aos limites propostos nesse artigo.

3. No curso de História da Universidade Estadual de Ponta Grossa (UEPG), há a divisão entre Bacharelado em História (período vespertino) e Licenciatura em História (período noturno).

4. Foram entrevistados quatro acadêmicos da Licenciatura em História, do último ano do curso (4 ano), os quais receberam os códigos: $\mathrm{H} 1, \mathrm{H} 2, \mathrm{H} 3$ e H4, preservando, desse modo, seus nomes.

\section{REFERÊNCIAS}

APPLE, Michael W. Educação e poder. Porto Alegre: Artes Médicas, 1989.

BAUMAN, Zygmunt. Identidade. Rio de Janeiro: Zahar, 2005.

BONAMINO, Alicia; MARTINEZ, Sílvia A. Diretrizes e Parâmetros Curriculares Nacionais para o ensino fundamental: a participação das instâncias políticas do Estado. Educação \& Sociedade. Campinas, v. 23, n. 80, setembro, 2002.

BRASIL. Orientação para as Diretrizes Curriculares dos Cursos de Graduação. Parecer 776/97. Brasília: Conselho Nacional de Educação, 1997.

. Diretrizes Curriculares Nacionais. Brasília: Conselho Nacional de Educação, 1997 b.

. Diretrizes Curriculares Nacionais para os Cursos de História. Brasília: Conselho Nacional de Educação, 2001.

. Referencial para as Diretrizes Curriculares Nacionais dos Cursos de Graduação. Parecer 67/2003. Conselho Nacional de Educação. Brasília: CNE, 2003.

CATANI, Afrânio M; OLIVEIRA, João F. de; DOURADO, Luiz F. Mudanças no mundo do trabalho e reforma curricular dos cursos de graduação no Brasil. Educação \& Sociedade. Campinas, v. 20, n. 1, agosto, 2001. 
CERRI, Luís F. Separando gêmeos ciência e docência nos novos currículos universitários de História. Publicatio. Ponta Grossa, n. 12, 2004.

CHOMSKY, Noam. Olucro ou as pessoas: neoliberalismo e ordem global. Rio de Janeiro: Bertrand Brasil, 2002.

FOUCAULT, Michel. A ordem do discurso. 13. ed. São Paulo: Loyola, 2006.

GIDDENS, Anthony. As Consequências da Modernidade. 2. ed. São Paulo: UNESP 1991.

GIROUX, Henry. Os professores como intelectuais: rumo a uma pedagogia crítica da aprendizagem. Porto Alegre: Artes Médicas, 1997.

. Cruzando as fronteiras do discurso educacional. Porto Alegre: Artes Médicas, 1999.

GNERRE, Maurizzio. Linguagem, escrita e poder. São Paulo: Martins Fontes. 1991.

HALL, Stuart. A identidade cultural na pós-modernidade. 3. ed. São Paulo: DP\&A, 1999.

KONDER, Leandro. A questão da ideologia. São Paulo: Companhia das Letras, 2002.

MCLAREN, Peter. A vida nas escolas: uma introdução à pedagogia crítica nos fundamentos da educação. 2. ed. Porto Alegre: Artes Médicas, 1997.

ORTIZ, Renato. Mundialização e Cultura. São Paulo: Brasiliense, 1996.

SANFELICE, José Luís. Pós-modernidade, globalização e educação. In: LOMBARDI, José Claudinei (Org). Globalização, pós-modernidade e educação. 2. ed. Santa Catarina: UNC, 2003.

UNIVERSIDADE ESTADUAL DE PONTA GROSSA. Projeto Pedagógico do Curso de História. Ponta Grossa: UEPG, Departamento de História, 2005.

XAVIER, Roseane. Representação social e ideologia: conceitos intercambiáveis? Psicologia e Sociedade. Santa Catarina, v.14, n.2, jul/dez, 2002.

WOLKMER, Antônio Carlos. Ideologia, Estado e Direito. 2. ed. São Paulo: RT, 1995.

Jonathan de Oliveira MOlar, graduado em História pela UEPG; mestre em Educação pela UEPG; Doutorando em Educação pela UFPR e pela UNLP (Arg); Docente do Colegiado de História da Universidade do Estado da Bahia (UNEB), classe de professor assistente. e-mail: jonathanmolar@hotmail.com 


\title{
TESES E DISSERTAÇÕES
}

Programa de Pós-Graduação em Educação da FE-UFG

\section{TESES}

\author{
Título: CRISE dA PESSOA E A CRISE DA EDUCAÇÃO: UM ESTUdO NA PERSPECTIVA \\ PERSONALISTA DE EMMANUEl MOUNIER. \\ Autor: Ricardo Almeida de Paula \\ Orientador: Dr. Adão José Peixoto \\ DEFENDIDA EM: 27/08/2010.
}

ResUmo: Esta tese tem como principal objetivo estudar o pensamento personalista de Emmanuel Mounier conforme apresentado nas Oeuvres editadas por Paulette Mounier em quatro volumes, publicadas pelas Editions du Seuil, de 1961 a 1963.0 personalismo constitui-se como um movimento de ampla renovação filosófica que tem como centro a pessoa. Desta sorte, o estudo do ser pessoa tem suas implicações na educação. Dentro de sua premissa antropológica cristã, a filosofia mounierista percebe o ser humano como dotado de uma imago, imagem, e, mediante sua transcendência, de imago Dei, imagem de Deus. O estudo das obras de Mounier, e de outros pensadores no contexto do personalismo e da filosofia da educação, nos deu a percepção da centralidade do papel da pessoa enquanto referência na contemporaneidade. $\mathrm{O}$ personalismo foi vivido como uma filosofia que tem a pessoa como centro, portanto, no âmbito de um humanismo integral; contudo, a idéia e o conceito de pessoa partem do cristianismo professado por Mounier, na forma de um humanismo cristão. Assim, afirmamos que o personalismo é uma filosofia. A problemática se instaura pelo fato de Mounier o ter assinalado mais como uma atitude do que como uma doutrina, embora o personalismo seja uma filosofia, a que não faltam o rigor e a sistematização. Porém, uma filosofia postulada fora dos muros acadêmicos, uma filosofia vivida e agida, uma proposta filosófica pluriforme, com o centro de convergência na pessoa humana. Elucidamos que o pensamento personalista não é subjacente à construção do pensamento filosófico brasileiro, ao contrário, foi proibido devido à confusão feita pelo regime militar, que o taxava de "marxista", "comunista" e, portanto, pernicioso à nação. Através dos movimentos sociais-comunitários como as CEBs, JEC, JUC, AP, dos quais participaram pensadores da ordem de Alceu Amoroso Lima e Henrique Lima Vaz, a consciência de ser pessoal num contexto educacional repressivo e foi de crucial 
importância para o desenvolvimento sócio-histórico-educacional no Brasil. Discutimos a concepção do termo "educação" mostrando-a como uma atitude transformadora e valorativa da pessoa, que visa todas as áreas da existência humana e, ainda, visa a transformação do ser da pessoa humana. Distinguimos a prática educativa da prática escolar institucionalizada - a primeira percebe a educabilidade humana e a segunda procura manter a ordem ideologicamente estabelecida. Concluímos que a crise percebida no meio educacional foi deflagrada pela ausência da pessoa como ser da educação. A ausência de uma antropologia mais definida, integral e específica sobre a pessoa humana, confere à educação um caráter variável a respeito do que se considera ser humano e humanização. Através do pensamento de Mounier, é possível retomar o conceito de pessoa enquanto tal, resgatando-o em seu aspecto comunitário-social e, ao mesmo tempo, como centro de toda proposta educacional.

PalaVRAs-Chave: Mounier. Personalismo. Pessoa. Imago. Imago Dei.

Título: "Quem deu à luz": a Comissão Pastoral da Terra (CPT) e as PRÁTICAS EDUCATIVAS NA FORMAÇÃO DE TRABALHADORES RURAIS EM GOIÁS.

AutOrA: Amone Inacia Alves

Orientador: Dr. Jadir de Morais Pessoa.

DEFENDIDA EM: 26/05/2010.

Resumo: Esse trabalho é fruto de uma pesquisa realizada no Programa de Pós-Graduação em Educação da Faculdade de Educação da UFG, na linha Trabalho e Movimentos Sociais, que tem como objeto de estudo a formação dos Trabalhadores Rurais pela Comissão Pastoral da Terra (CPT). Pretendemos mostrar quais práticas educativas foram mobilizadas para formar esses trabalhadores, tanto pelos seus próprios representantes, como pelos mediadores que vem fazendo sua formação no campo agrário. O suporte teórico dessa pesquisa foi a Teoria da Prática de Pierre Bourdieu, sobretudo, quanto ao aporte das Teorias de campo, habitus e capital social e cultural. Além da pesquisa bibliográfica e da análise de documentos, lançamos mão da etnografia, entrevistando agentes pastorais que participaram da CPT e antigos parceleiros que ocuparam a Fazenda São João do Bugre, localizada no Município da Cidade de Goiás (GO), no final dos anos 1980, primeiro núcleo de participação ativa da pastoral. A pesquisa possibilitou constatar que a CPT atuou no sentido de atribuir capital cultural e que existe um habitus em transição do trabalhador rural, que também é um agente coletivo, posto à prova diante das diversas vicissitudes do mundo do trabalho, que o empurram para o enfrentamento e para a organização em movimentos sociais.

Palavras-Chave: Práticas educativas. Mediação. Representação. 
TítulO: A ESCUTA DIFERENCIADA DAS DIFICULDADES DE APRENDIZAGEM: UM PENSARSENTIRAGIR INTEGRAL MEDIADO PELA MUSICOTERAPIA

Autora: Sandra Rocha do Nascimento

Orientadora: Dra. Maria Herminia M.S. Domingues

DEFENDIDA EM: 23/08/2010.

Resumo: A pesquisa, desenvolvida na linha de pesquisa Cultura e Processos Educacionais, tem como objeto de estudo as dificuldades de aprendizagem numa escola de tempo integral, com o objetivo de compreender suas manifestações e de propôr ações musicoterapêuticas para sua modificação. A metodologia baseou-se na pesquisa-ação integral, na perspectiva fenomenológica existencial, utilizando-se de diversas técnicas de coleta de dados e ações musicoterapêuticas interdisciplinares, numa atuação multidirecional sustentada na escuta musicoterapêutica, mediando experiências, ações e compreensões. Os resultados apontaram para três categorias axiais: espaço de vida interinfluentes, percepções intersubjetivas e atos inter-reflexivos, indicando que as dificuldades de aprendizagem devem ser vistas a partir de um olhar diferenciado e ampliado, no qual a musicoterapia se configura como espaço-tempo de trans-formação das dimensões do pensar, sentir e agir. O referencial teórico é subsidiário de Merleau-Ponty, em sua proposta analítica da hiperdialética, posto em diálogo com outros teóricos. Semelhante à complexidade do real, as dificuldades de aprendizagem e os multifatores interinfluentes são explicados por diferentes abordagens, através de estudos das áreas de Educação, Psicologia e Musicoterapia. As dificuldades de aprendizagem foram compreendidas de forma ampliada, por meio de uma escuta diferenciada que integrou saberes e discursos em lócus variados, propícios à apreensão da mútua constituição entre sujeitos e meio. A partir dessa compreensão integral, conformamos a categoria seletiva - pensarsentiragir - levando a uma mudança de olhar sobre os fenômenos, em que as dificuldades de aprendizagem se apresentam como uma dissonância entre pensarsentiragir.

Palavras-Chave: Musicoterapia na Educação. Escola de Tempo Integral. Dificuldades de aprendizagem. 


\title{
DisSERTAÇõES
}

\author{
Título: DocênCIA UNIVERSITÁRIA EM ARTE: (AUTO)RETRATOS DA IDENTIDADE \\ DOCENTE-ARTISTA. \\ AutOrA: Eleny Macedo de Oliveira \\ Orientadora: Dra. Monique Andries Nogueira \\ DEFENDIDA EM: 10/06/2010
}

Resumo: O presente estudo, vinculado à linha de pesquisa Formação e Profissionalização Docente, buscou identificar e analisar a identidade profissional do docente-artista que atua na Educação Superior. O docente-artista é conceituado como aquele que atua com as diferentes linguagens artísticas no Ensino Superior, com produção artística ou não. De posse desse conceito recorre-se à trajetória das primeiras instituições de Ensino Superior no Brasil, com o intuito de elucidar como aconteceu a gênese da formação do docente universitário ao longo da história, em especial do docente-artista. Essas informações servem de alicerce para se conhecer a evolução da formação profissional e da identidade do docente-artista da Educação Superior, em interlocução com Luiz Antonio Cunha e Ana Mae Barbosa. As análises sobre a identidade profissional ganham consistência, se acompanhadas das reflexões de Selma Garrido Pimenta e Miguel Zabalza. A pesquisa de campo realizada junto a docentes-artistas teve como instrumento para coleta de dados o questionário. As conclusões advindas das análises da pesquisa de campo e as possíveis contribuições para a compreensão dos aspectos que constituem a identidade profissional do docente-artista da Educação Superior formam o desfecho desta investigação, com a apresentação de duas grandes linhas identitárias. A primeira linha é composta por docentes-artistas com características mais voltadas para a identidade de educador. A segunda linha apresenta contornos em que se acentua a identidade de artista em detrimento da visão de educador. São identidades distintas para a docência em Arte, com propósitos semelhantes aos daqueles que atuam nos cursos de formação de professores.

Palavras-chave: Docência universitária em Arte. Identidade do docente-artista. Identidade profissional. 
TítuLO: INOVAÇÃO EDUCACIONAL E FORMAÇÃO DE PROFESSORES: EM BUSCA DA RUPTURA PARADIGMÁTICA

AutOrA: Irelmá Pires Araújo Matos

Orientadora: Dra. Ruth Catarina Cerqueira Ribeiro de Souza.

DEFENDIDA EM: 26/08/2010

RESUMO: A dinâmica social do mundo globalizado contemporâneo e suas repercussões na educação requerem dos professores mudanças na estratégia pedagógica para superar as dificuldades que alunos têm demonstrado durante o processo de construção do conhecimento. O presente estudo, inserido na linha de pesquisa Formação e Profissionalização Docente, versa sobre a questão da inovação no âmbito educacional brasileiro. O objetivo é conhecer e analisar os conceitos e concepções que envolvem essa temática, tendo em vista sua importância nos projetos de formação de professores que almejam a melhoria da educação. O alvo foi, principalmente, identificar e analisar, no período de 2005-2009, o que se tem publicado nos eventos educacionais organizados no Brasil (Associação Nacional de Pós-Graduação e Pesquisa em Educação (ANPED), Encontro Nacional de Didática e Prática de Ensino (ENDIPE); Rede de Estudos sobre o Trabalho Docente (REDESTRADO); Congressos Nacionais e Internacional de Educação) e em Banco de dados de universidades da pós-graduação de universidades sobre essa temática. Propôs-se, ainda, analisar criticamente os desafios da universidade diante do processo de formação e profissionalização docente, evidenciando rupturas com os paradigmas tradicionais. A metodologia de natureza teórica e empírica adotada consistiu da análise bibliográfica, em que se utilizou de parâmetros qualiquantitativos, na busca de uma melhor visualização dos resultados. Para tanto, coletaram-se informações por meio de roteiros de leituras a partir dos títulos e resumos que apresentassem as palavras "inovar", "inovação", "mudanças", "rupturas", "paradigmas", "práticas significativas", "reformas", e/ou "publicações", cujos títulos se referiam de algum modo à inovação. Ao todo foram catalogados 211 trabalhos, dos quais selecionou-se para análise 36 trabalhos da ANPED - considerada no meio acadêmico a reunião mais representativa da educação no Brasil - fazendo-se um diálogo com outros dados coletados. Ressalta-se que as concepções de inovação que apareceram nessas publicações da ANPED são diversificadas. Nos trabalhos analisados no período 2005-2009, percebeu-se, quanto ao tipo de inovação abordada, que a maioria refere-se ao fazer pedagógico do professor, e que não há um número expressivo de trabalhos que caminhou na perspectiva da inovação epistemológica, defendida nessa dissertação. Os conceitos de inovação encontrados, em geral são ambíguos, e a maioria das propostas sugeridas não é aprofundada e fundamentada. Conclui-se que a concepção de inovação é uma questão complexa e desafiadora e que, embora ainda moldada pelo paradigma tradicional, pode ser provocada a partir de rupturas epistemológicas. Assim, constroem-se novos caminhos na educação fundamentados em diálogos articulados entre as instituições e seus agentes.

PalAVRAS-Chave: Educação. Formação de professores. Inovação. Rupturas. Paradigmas. 
Título: AVALIAÇÃo edUCACIONAL E A PRODUÇĀO DA SUBMISSÃO: ANÁLISE CRÍTICA À LUZ DE THEOdOR WIESENGRUNd Adorno.

Autor: Anderson de Sousa Coelho.

OrIEnTADORA: Dra. Silvia Rosa Silva Zanolla.

DEFENDIDA EM: 30/08/2010.

Resumo: Esta pesquisa vincula-se a linha de pesquisa Cultura e Processos Educacionais e tem como objeto de estudo o desvendamento da formação cultural a partir da razão instrumental (ou tecnicista) projetada pelo capitalismo neoliberal na década de 1990. A pesquisa busca desvelar os aspectos ideológicos que determinam o papel da educação e da avaliação educacional delineada com base em valores e princípios projetados pela classe dominante (burguesia). Definiu-se como procedimento metodológico a pesquisa bibliográfica e como referencial teórico-metodológico a análise críticoreflexiva das obras clássicas da Teoria Crítica da Escola de Frankfurt, principalmente a epistemologia de Adorno e alguns intelectuais, tais como: Horkheimer, Marcuse e Benjamin. Pretende-se, com os resultados da pesquisa, argumentar sobre o potencial da Teoria Crítica no debate acerca de questões da relação entre a educação, a avaliação educacional e a sociedade capitalista neoliberal, com destaque para o Brasil. Com base no que Adorno apontou como possibilidade de uma "educação para a emancipação", procura-se demonstrar a potencialidade do autor para sustentar, teoricamente, ações educativas, que privilegiem a esfera avaliativa educacional de modo comprometido com a liberdade dos indivíduos.

Palavras-chave: Avaliação Educacional. Teoria Crítica. Educação e Cultura Brasileira.

\section{TítuLO: A FORMAÇÃO DO EDUCADOR NA SOCIEDADE DO COMPUTADOR}

AutorA: Roselle Fonseca da Silva Balduino Valente

ORIENTADOR: Dr. Ged Guimarães.

DEFENDIDA EM: 21/08/2010.

Resumo: Este trabalho insere-se na linha de pesquisa Cultura e Processos Educacionais, do Programa de Pós-Graduação em Educação da FE/UFG. Investigou-se a formação de educadores na era tecnológica, buscando compreender o que é a tecnologia da informação e quais os diferentes tipos de softwares utilizados no processo ensinoaprendizagem. Buscamos demonstrar como é o funcionamento da parte física e lógica do computador e como se dá a instrumentalização da formação de educadores por meio da tecnologia. Acreditamos que a formação não pode ser reduzida aos interesses imediatistas exigidos pelo mercado. É preciso saber qual o sentido da formação, do 
ensino, do saber, da cultura. A realização da pesquisa buscou compreender que o ato de educar e de formar é um movimento permanente de homens que procuram elevar o pensamento, os conceitos, que saibam questionar as ideias e busquem construir o novo.

Palavras-Chave: Educador. Formação. Tecnologia.

Título: OS SABERES DOCENTES E A EXPLORAÇÃO SEXUAL COMERCIAL DE MENINAS: DESAFIOS DA CONTEMPORANEIDADE.

AutOrA: Railda Gonçalves Martins.

Orientadora: Dra. Ruth Catarina Cerqueira Ribeiro de Souza.

DEFENDIDA EM: 27/08/2010.

RESUMO: O presente trabalho insere-se na linha de pesquisa Formação e Profissionalização Docente. O objetivo da investigação é conhecer quais são os valores que os professores e as professoras expressam ao lidarem com a adolescente envolvida com a exploração sexual comercial. O professor e a professora apresentam-se como personagens fundamentais no processo de socialização do indivíduo, uma vez que a escola é composta por sujeitos imersos em realidades históricas, sociais e culturais, cujos referenciais influenciam diretamente a construção e a assimilação de valores por parte de seus alunos e suas alunas. Para conhecimento desses valores, foram realizadas pesquisas bibliográfica e de campo. Na pesquisa bibliográfica, o caminho percorrido consulta autores clássicos e contemporâneos que se debruçaram em estudos relacionados com a temática, como também investigações que tiveram como objeto de estudo a questão da exploração sexual de adolescentes, tanto no Brasil quanto no exterior. Em relação à formação de professores e de professoras, a discussão teve como foco os saberes docentes, e, como suporte para sua compreensão, obras de autores que lidam com essa temática. Trata-se de uma pesquisa qualitativa, cuja investigação empírica aconteceu em duas escolas do município de Goiânia (GO). Os instrumentos de coleta de dados utilizados foram: questionários, vídeos referentes à temática da exploração sexual comercial de adolescentes (ESCCA) e a técnica do grupo focal. Os dados coletados e analisados permitiram constatar que os professores e as professoras desconhecem a diferença entre prostituição e ESCCA. Em relação ao que fazer quando percebem casos de ESCCA, ficou evidenciado que não sabem o que fazer e como encaminhar o problema para as instâncias de defesa e proteção, como o Conselho Tutelar; ou seja, desconhecem o seu papel e como estabelecer articulação com essa instância. No tocante às situações em que as adolescentes estão envolvidas com a ESCCA percebe-se que alguns professores e algumas professoras têm dificuldade em compreender que o adulto é o responsável. Apontam que a família desempenhava um papel mais rigoroso e que atualmente é diferente, pois falta autoridade de uma pessoa que comande, seja o pai ou a mãe. Expressam que a sexualidade está mais 
presente e que a mídia fortalece essas questões influenciando as adolescentes de forma alienada mas eficaz, que as meninas estão envolvidas com a ESCCA pela falta de religião. Constatou-se que a formação acadêmica não tem subsidiado, teórica e praticamente, os professores e as professoras para lidarem com ESCCA, e que eles recorrem aos saberes oriundos da prática profissional, de revistas e jornais, de conversas com familiares, entre amigos, colegas da escola, pela televisão, pela Igreja. Os dados evidenciaram que o projeto político-pedagógico das duas escolas não aborda a questão da violência sexual, em especial a ESCCA, apesar de serem escolas em que essa realidade está presente.

PaLAVRAS-CHAVE: Saberes docentes. Valores. Exploração sexual comercial de adolescentes (ESCCA).

Título: FoucAult e A eSCOLA: DISCIPLINAR, EXAMINAR, FABrICAR

Autora: Thelma Maria de Moura

Orientador: Ildeu Moreira Coêlho

DEFENDIDA EM: 24/08/2010

Resumo: Na Modernidade, a educação foi investida da grandiosa tarefa de esclarecer e emancipar o homem, dando-lhe condições de construção de sua liberdade moral. Simultaneamente à produção dos discursos disseminadores dessa concepção, a escola tornou-se alvo de discursos que, apoiados em estatísticas de evasão e repetência e indisciplina, afirmam o fracasso dessa instituição enquanto espaço formativo. Diante dessa questão, este trabalho, inserido na linha de pesquisa Cultura e Processos Educacionais, objetiva discutir a função da escola disciplinar enquanto espaço formador de subjetividades, a partir da análise do pensamento do filósofo Michel Foucault. Tendo como suposto que, dentro da sociedade disciplinar, a escola assume a forma de uma instituição de sequestro, em que as técnicas disciplinares de controle temporal do corpo e do ato, a rigorosa distribuição espacial, o horário e o exame concorrem para o estabelecimento de um padrão Normal que se constitui ao mesmo tempo em um dispositivo de poder e em uma forma de saber, analisa a eficiência da instituição escolar no processo de produção de saberes sobre o sujeito ao mesmo tempo que produz uma subjetividade dócil e submissa aos dispositivos disciplinares. São apresentadas as dimensões arqueológica e genealógica da obra foucaultiana com o objetivo de analisar a formação do sujeito "moderno", "disciplinado", sobre o qual o poder atua sob a forma de um saber-poder normalizador. A análise do pensamento de Foucault possibilita afirmar que, no interior das estratégias disciplinares, a escola encontra-se em uma situação de identidade com outras instituições - prisão, hospital, fábrica. Responsáveis pela produção de saberes específicos sobre os indivíduos, as ciências humanas, por sua vez, retornam sob a forma de técnicas disciplinares capazes de produzir novas subjetividades. $O$ estudo sugere a necessidade da construção de 
um novo modelo educativo, capaz de criar uma atitude de modernidade frente ao saber e de formar sujeitos capazes de romper com as estratégias do poder disciplinar, adotando uma postura de invenção frente ao conhecimento.

Palavras-chave: Saber-Poder. Disciplina. Escola.

\author{
Título: A política de cotas da Universidade Federal do Tocantins: \\ CONCEPÇÃO E IMPLICAÇÕES PARA A PERMANÊNCIA DOS ESTUDANTES INDÍGENAS. \\ Autora: Doracy Dias Aguiar de Carvalho \\ Orientadora: Dra. Marília Fonseca \\ DEFENDIDA EM: 30/06/2010
}

Resumo: O presente estudo integra a linha de pesquisa Estado e Políticas Educacionais, do Programa de Pós-Graduação em Educação da Faculdade de Educação da UFG. Toma como objeto de estudo a política de cotas para indígenas da Universidade Federal do Tocantins e busca compreender a concepção de inclusão a esta subjacente e suas implicações para a permanência dos estudantes indígenas. A pesquisa constitui-se num estudo de caso e situa-se no âmbito do debate sobre a democratização do acesso à educação superior brasileira, por meio das ações afirmativas. Tomou-se como referências teóricas estudos de vários estudiosos do tema. A partir de uma abordagem histórico-estrutural-dialética levou-se em conta as especificidades e a complexidade do objeto de estudo sem perder de vista as suas conexões com a realidade social mais ampla sob o ponto de vista econômico, social, político e cultural. O estudo teve como lócus empírico a Universidade Federal de Tocantins (UFT), Campus de Palmas, e como interlocutores estudantes indígenas, professores, gestores e técnicoadministrativos envolvidos diretamente com a política de cotas da Universidade. Como fonte documental foram examinados relatórios, atas, boletins, resoluções, planos, leis, portarias, constituições federais, decretos, folders, material eletrônico, dentre outros documentos oficiais e institucionais afins. Evidenciou-se, a partir do entrelaçamento dos dados empíricos com as formulações teóricas, que a concepção de inclusão subjacente à política de cotas da UFT tem como foco central o acesso, deixando para segundo plano a permanência dos estudantes indígenas, a qual vem sendo viabilizada a partir de ações fragmentadas, pontuais e instáveis. Trata-se de uma inclusão, de certo modo, excludente, na medida em que, de um lado, absorve as demandas dos indígenas no que tange à garantia de acesso, e, de outro, não lhes provê as condições básicas de manutenção e de estudo. Não obstante, há que se reconhecer que a iniciativa da UFT, sob o ponto de vista do acesso dos povos indígenas à educação superior, representa uma relevante iniciativa; todavia, a inclusão dessas minorias requer a melhoria significativa dessa política no que tange à permanência, com qualidade, dos estudantes indígenas na referida Instituição de Ensino.

PalavRAS-Chave: Educação superior. Acesso-permanência. Ações afirmativas. 



\section{NORMAS PARA PUBLICAÇÃO}

A revista Inter-Ação aceita para publicação artigos, ensaios, resenhas e outros textos acadêmicos (conferência, entrevista, palestra, etc.) inéditos, escritos em português ou em outras línguas, resultantes de estudos teóricos e pesquisas que incidem na produção do conhecimento sobre a educação, abrangendo, principalmente, as seguintes temáticas ou linhas de pesquisa: Cultura e processos educacionais; Educação, trabalho e movimentos sociais; Estado, políticas e história da educação; Formação, profissionalização docente, práticas educativas; e Fundamentos dos processos educativos.

A avaliação dos trabalhos será realizada por membros do Conselho editorial (pares cegos) ou, excepcionalmente, por pareceristas ad hoc. Em caso de pareceres divergentes recorrer-se-á a um terceiro. Eventuais sugestões de modificações por parte da editoria serão elaboradas com o consenso dos autores. Os textos publicados expressam opiniões de exclusiva responsabilidade de seus autores, não representando necessariamente o ponto de vista do Conselho Editorial.

Todos os trabalhos devem ser enviados por meio do Sistema Eletrônico de Editoração de Revista (SEER), ao endereço: http://www.revistas.ufg.br/ index.php/interacao/index. O texto deve estar gravado em formato Microsoft Word e toda e qualquer possível identificação de autoria deverá ser retirada do documento, pois a identificação de autoria é feita por meio dos metadados.

Os metadados (o termo "metadados" refere-se ao preenchimento de alguns campos no momento da submissão do documento) deverão ser preenchidos com nome(s) do(s) autor(es), instituição a que pertence, e-mail, endereço postal e telefone do(s) autor(es) para que a revista impressa seja enviada; preenchimento do título e do resumo na língua do artigo e em inglês. É necessário, também, uma breve descrição no item biografia, que será incluída no final do artigo.

O texto deverá ser digitado em editor de texto Word, fonte Times New Roman, tamanho 12, espaçamento entre linhas de 1,5, com margens de $3 \mathrm{~cm}$. O número máximo de laudas, para as diferentes colaborações, deve ser: 18 para artigos, 5 para resenhas e 12 para ensaios e comunicações científicas. 
Os artigos deverão apresentar, no início, um resumo de, no máximo, 10 linhas, contendo objetivos, métodos principais, conclusões e quatro palavras-chave na língua do documento. Devem apresentar também o título, o resumo e as palavras-chaves em uma versão em inglês no final do texto e antes das referências. Para maiores informações sobre a estrutura do artigo, consulte a norma da ABNTNBR 6022/2003 informação e documentação-Artigo em publicação periódica científica impressa. Para saber sobre a elaboração de resumos, consulte a norma da ABNT NBR 6028/2003 informação e documentação-Resumo.

Todas as citações deverão ser apresentadas conforme a norma da ABNT NBR 10520/2002 informação e documentação-citações em documentos. São regras gerais: citações diretas com até 3 linhas são reproduzidas entre aspas duplas exatamente como consta do original, no interior do texto e com a indicação da fonte (AUTOR, ano da obra, página). Citações diretas com mais de 3 linhas deverão figurar com recuo de $4 \mathrm{~cm}$ da margem esquerda, com letra tamanho 10 e com espaçamento simples entre linhas, dispensando as aspas e com a indicação da fonte (AUTOR, ano da obra, página). As citações indiretas são inseridas no interior do texto com a indicação da fonte (Autor e ano da obra em questão).

OUTRAS OBSERVAÇÕES IMPORTANTES: as notas devem ser objetivas, de natureza substantiva, numeradas e colocadas no final do texto (antes das referências), ou seja, as notas devem abarcar comentários e não meras indicações de autor e obra; as siglas e as abreviações devem aparecer estendidas, quando citadas pela primeira vez no texto; os quadros, gráficos, mapas e ilustrações, se forem indispensáveis à compreensão do documento, devem ser inseridos o mais próximo possível do trecho a que se referem, numerados e com a indicação de suas respectivas fontes; as tabelas inseridas no interior do texto deverão seguir as orientações do IBGE para apresentação de tabelas.

As referências bibliográficas deverão ser apresentadas ao final do artigo, em ordem alfabética. Para ênfase ou destaque utilizar itálico e não negrito. As referências deverão ser alinhadas somente à esquerda, em espaçamento simples entre linhas. Consulte a norma da ABNTNBR6023/2002 informação e documentação-referências.

Exemplos (atenção às maiúsculas e aos itálicos):

a) LIVRO NO TODO COM UM SÓ AUTOR:

SOBRENOME, Nome. Título: subtítulo. Edição. Local de publicação: Editora, data.

Ex.: GOMES, L. G. F. F. Novela e sociedade no Brasil. Niterói: EdUFF, 1998. 
b) LIVRO NO TODO COM DOIS OU TRES AUTORES:

SOBRENOME, Nome; SOBRENOME, Nome. Título: subtítulo. Edição. Local de publicação: Editora, data.

Ex.: NUDELMANN, A. A.; COSTA, E. A.; SELIGMAN, J. (Org.). PAIR: perda

auditiva induzida pelo ruído. Porto Alegre: Bagaggem Comunicação, 1997.

c) LIVRO NO TODO COM MAIS DE TRES AUTORES:

SOBRENOME, Nome et al. Título: subtítulo. Tradutor. Edição. Local de publicação: Editora, data.

Ex.: FAZZI, R. et al. Organização do consultório. In: GUEDES PINTO, A.C. Odontopediatria (Org.). 4. ed. São Paulo: Editora Santos, 2003. p. 933-958.

d) Capítulos de livros:

SOBRENOME, Nome do autor do capítulo.Título do capítulo. In: SOBRENOME, Nome do autor/organizador do livro. Título do livro. Edição. Local de publicação: Editora, data. Página.

Ex.: BERTICELLI, Ireno Antônio. Currículo: tendências e filosofia. In: COSTA, Marisa Vorraber (Org.). O currículo nos limiares do contemporâneo. Rio de Janeiro: DP\&A, 1999. p. 159-176.

e) ARTigos em PeRIÓdICOS:

SOBRENOME, Nome do autor artigo. Título do artigo. Título do periódico, número do volume, página inicial-final, ano.

CANEN, Ana e OLIVEIRA, Ângela M. A. de. Multiculturalismo e currículo em ação: um estudo de caso. Revista Brasileira de Educação, Rio de Janeiro, n 21, p. 61-74, set/out/ nov/dez. 2002.

f) DISSERTAÇÕES E TESES:

SOBRENOME, Nome. Título: subtítulo. Ano. Dissertação? ou Tese? (Grau e Área de concentração) - Nome da Escola, Universidade.

RODRIGUES, Maria Emilia de Castro. A prática do professor na educação de adolescentes, jovens e adultos: a experiência do Projeto AJA de Goiânia-GO. Dissertação (Mestrado em Educação Brasileira) - Faculdade de Educação, Universidade Federal de Goiás, Goiânia, GO, 2000.

Os textos enviados à revista Inter-Ação devem ser direcionados para uma das seguintes seções:

SEção Dosslé: Seção na qual são publicados artigos, ensaios ou comunicações científicas que contemplem a temática do dossiê, conforme Chamada para publicação, divulgada anteriormente. 
SEÇÃO ARTIGOS: A seção artigos é composta por artigos científicos de assuntos condizentes com o foco e o escopo da revista, não precisando contemplar a temática do dossiê.

SEÇÃo RESENHA: Esta seção destina-se à publicação de resenhas, ou seja, à exposição concisa do que é apresentado em obras relevantes ao foco e escopo da Inter-Ação.

SEÇÃO ENSAIO: A seção ensaio destina-se à publicação de textos que tratam de um recorte específico numa temática e que, embora não sejam extensos e nem tenham a profundidade de um artigo, situam essa temática com relação à área estudada.

SEÇÃo COMUNICAÇõES CIENTífICAS: Esta seção recebe textos que são, geralmente, fruto de apresentações em congressos, como palestras, conferências ou outros trabalhos.

SEÇÃO TESES E DISSERTAÇÕES: Esta seção destina-se à publicação dos resumos de teses e dissertações defendidas no Programa de Pós-Graduação em Educação da Faculdade de Educação da UFG.

SEÇÃo DOCUMENTO: Esta seção, utilizada apenas pelo Corpo Editorial, destina-se à publicação de documentos oficiais, ou seja, geralmente assinados por alguma instância, e não por pessoas. Ex: leis, projetos, regulamentos, manifestos, etc.

OBSERVAÇÃO: quando impressa a revista, os autores receberão três exemplares do número em que os seus artigos forem publicados.

Para informações complementares: (62) 3209-6319 ou revistainteracao@ gmail.com. 

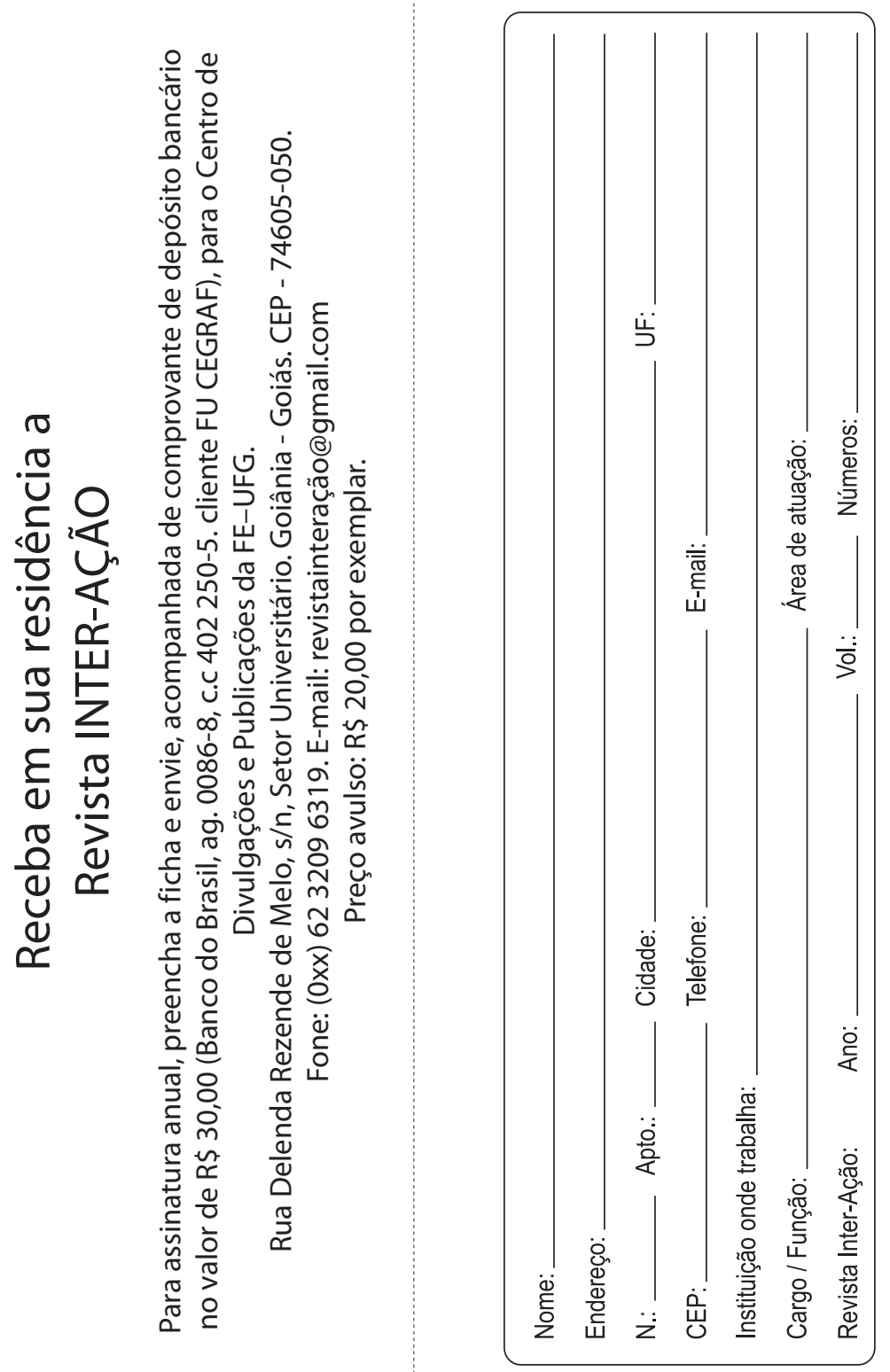

$x$ 
